\title{
The T.C. Osborn Tenant Farm, 41BP314: An Early Sharecropper Site in Bastrop County, Texas
}

José E. Zapata

Center for Archeological Research, University of Texas at San Antonio

Follow this and additional works at: https://scholarworks.sfasu.edu/ita

Part of the American Material Culture Commons, Archaeological Anthropology Commons, Environmental Studies Commons, Other American Studies Commons, Other Arts and Humanities Commons, Other History of Art, Architecture, and Archaeology Commons, and the United States History Commons

Tell us how this article helped you.

This Article is brought to you for free and open access by the Center for Regional Heritage Research at SFA ScholarWorks. It has been accepted for inclusion in Index of Texas Archaeology: Open Access Gray Literature from the Lone Star State by an authorized editor of SFA ScholarWorks. For more information, please contact cdsscholarworks@sfasu.edu. 


\section{The T.C. Osborn Tenant Farm, 41BP314: An Early Sharecropper Site in Bastrop County, Texas}

\section{Licensing Statement}

This is a work produced for the Texas Department of Transportation (TxDOT) by the report producer. TxDOT and the report producer jointly own all rights, title, and interest in and to all intellectual property developed under TXDOT's contract with the report producer. The report may be cited and brief passages from this publication may be reproduced without permission provided that credit is given to both TXDOT and the report producer. Permission to reprint an entire chapter, section, figures or tables must be obtained in advance from either the Supervisor of the Archeological Studies Branch, Environmental Affairs Division, Texas Department of Transportation, 125 East 11th Street, Austin, Texas, 78701 or from the report producer. 


\section{The T. C. Osborn Tenant Farm, 41BP3 14: An Early Sharecropper Site in Bastrop County, Texas}

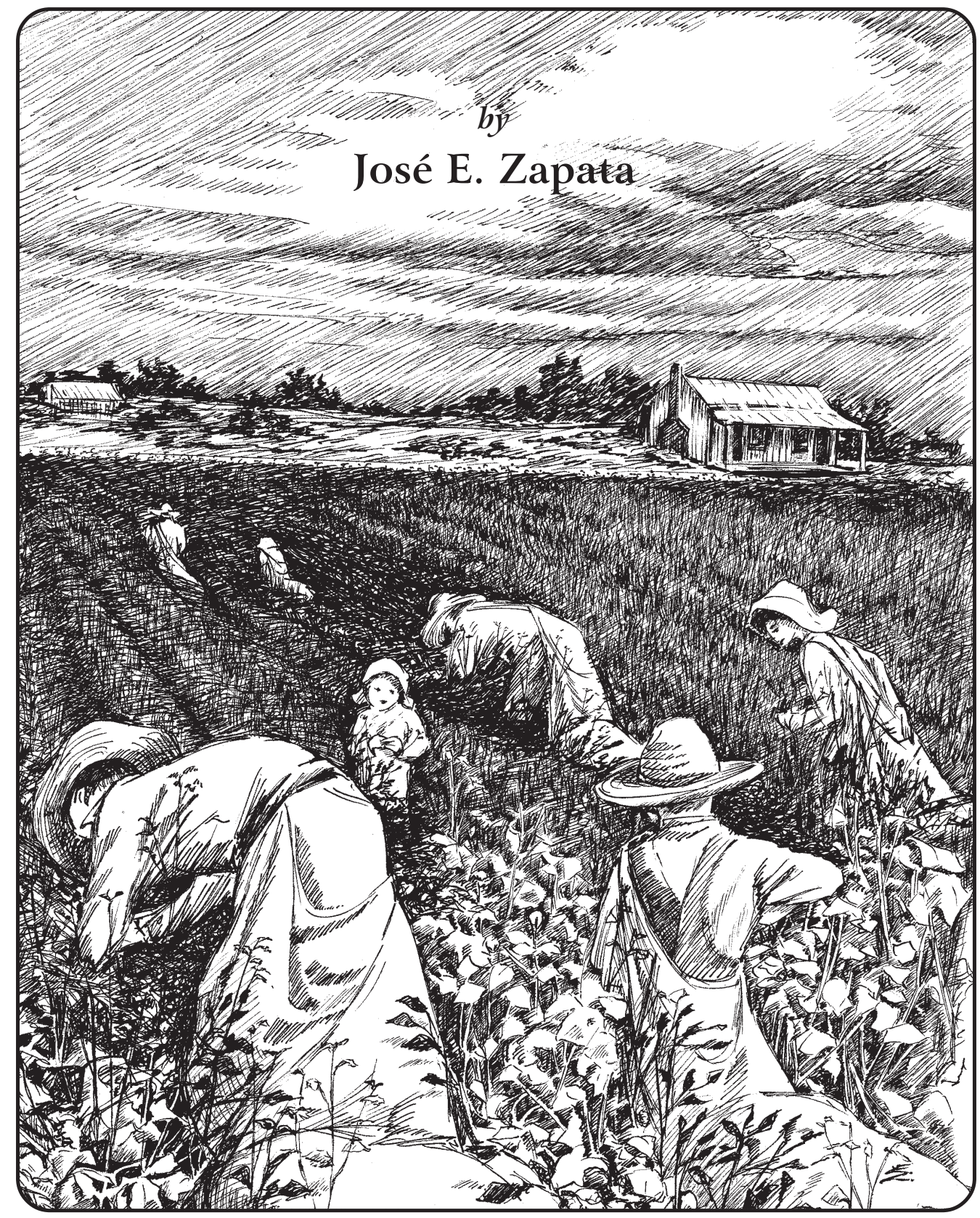

with a contribution by

Barbara A. Meissner

Prepared for:

Texas Department of Transportation

Environmental Affairs Division

Archeological Studies Program, Report No. 31
Prepared by:

Center for Archaeological Research The University of Texas at San Antonio Archaeological Survey Report, No. 309 
ISBN: 1-930788-11-8 


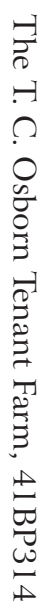

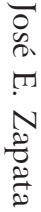

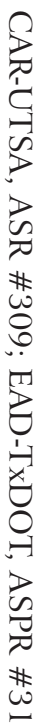

$\stackrel{8}{8}$ 


\title{
The T. C. Osborn Tenant Farm, 41BP3 14: An Early Sharecropper Site in Bastrop County, Texas
}

\author{
by \\ José E. Zapata
}

with a contribution by

Barbara A. Meissner

Nancy A. Kenmotsu

Principal Investigator

Texas Antiquities Permit No. 598

Prepared for:

Texas Department of Transportation Environmental Affairs Division

Archeological Studies Program, Report No. 31

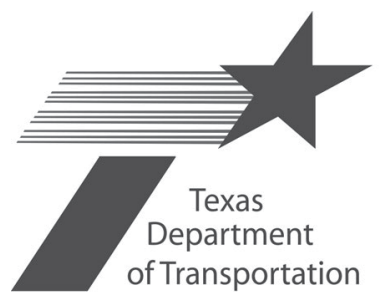

Prepared by:

Center for Archaeological Research The University of Texas at San Antonio Archaeological Survey Report, No. 309

2001

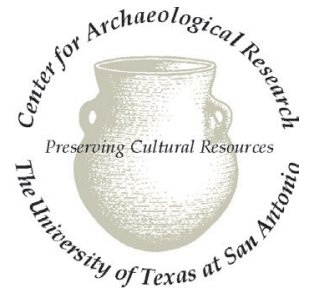


The T. C. Osborn Tenant Farm, 41BP314:

An Early Sharecropper Site in Bastrop County, Texas

\author{
Copyright (C2001 \\ Texas Department of Transportation (TxDOT) and Center for Archaeological Research, \\ The University of Texas at San Antonio (CAR-UTSA)
}

\begin{abstract}
All rights reserved
TxDOT and CAR-UTSA jointly own all rights, title, and interest in and to all data and other information developed for this project. Brief passages from this publication may be reproduced without permission provided that credit is given to TxDOT and CAR-UTSA. Permission to reprint an entire chapter, section, figures or tables must be obtained in advance from the Supervisor of the Archeological Studies Program, Environmental Affairs Division, Texas Department of Transportation, 125 East $11^{\text {th }}$ Street, Austin, Texas, 78701. Copies of this publication have been deposited with the Texas State Library in compliance with the State Depository requirements.
\end{abstract}
Printed by Kwik Kopy Printing San Antonio, Texas
2001

jointly published by

Texas Department of Transportation

Environmental Affairs Division

Archeological Studies Program

Nancy A. Kenmotsu, Ph.D., Supervisor

Archeological Studies Program, Report No. 31

A. McGraw, Series Editor

and

Center for Archaeological Research

The University of Texas at San Antonio

Archaeological Survey Report, No. 309

Printed on acid-free, $60 \mathrm{lb}$. paper

ISBN: 1-930788-11-8 


\begin{abstract}
The T. C. Osborn tenant site was located in Bastrop, Bastrop County, about 1,300 ft. (410 m) east of the juncture of Gills Branch Creek and the Colorado River, along the path of present-day Lovers Lane, and just south of State Highway 71. This site was determined eligible for the National Register of Historic Places and investigated in February and March 1987 by John W. Clark of the Texas Department of Transportation, prior to being impacted by the construction of Lovers Lane. A total of 32 units were excavated, and the recovered artifacts include ceramic sherds, glass fragments, beads and marbles, cut and wire nails, assorted metal objects, buttons, and bone fragments. This site also underwent Historic American Building Survey, Level 3 documentation, so that a series of measured drawings of the demolished four-room board-and-batten home are also available. A site history of the property discovered that the board-and-batten home was constructed ca. 1906 by T. C. Osborn for the use of tenant farm families. The artifactual, archival, and oral history data indicates that this site was occupied by at least two Mexican and Mexican-American families between ca. 1906 and 1941. The matriarch of one of these tenant families, 93-year-old Louise García, resides within four blocks of the original site, and contributed an oral history to this inquiry. The personal narratives furnished by former Osborn Farm tenant families were critical to achieving a synthesis of the data.
\end{abstract}

All cultural materials, field notes, forms, and photographs were retained at the Center for Archaeological Research at The University of Texas at San Antonio for permanent curation. 


\section{Contents}

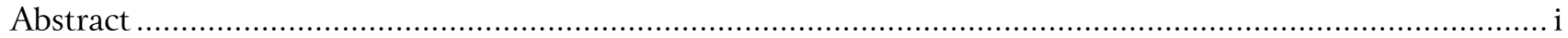

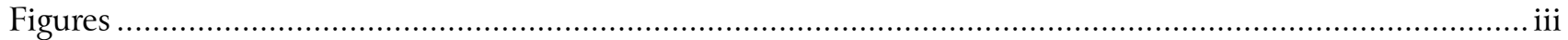

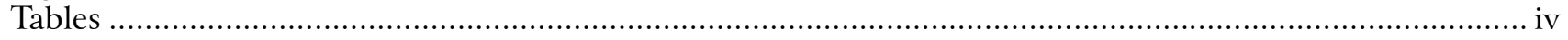

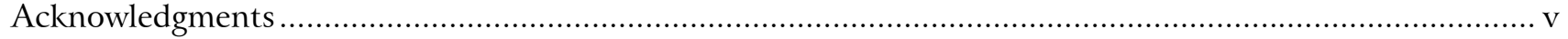

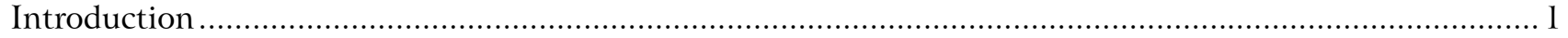

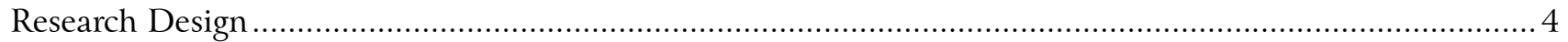

Mexican Migration Patterns into Central Texas .......................................................................... 4

Social Relations within an Early Twentieth Century Rural Community ............................................. 4

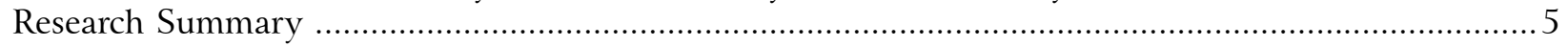

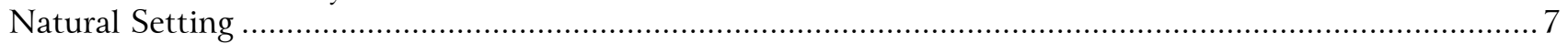

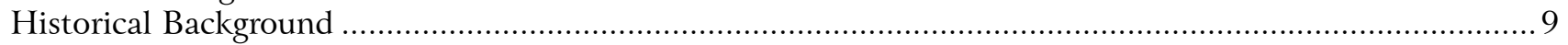

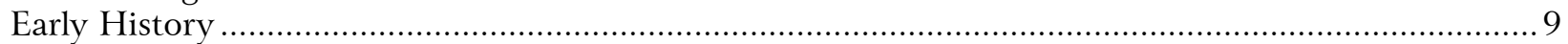

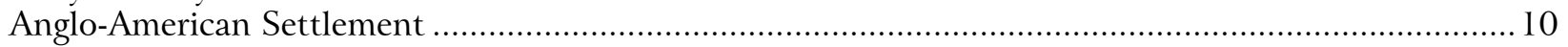

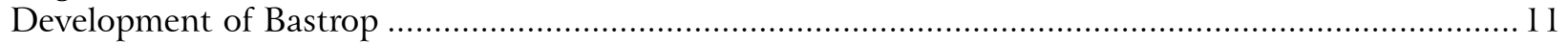

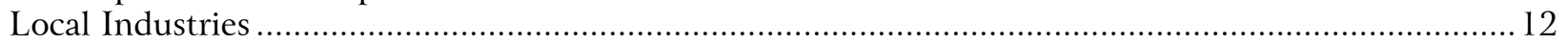

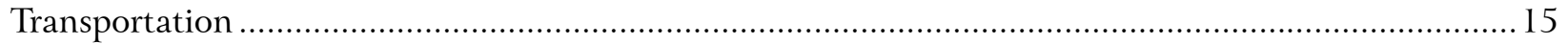

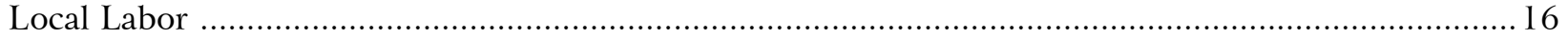

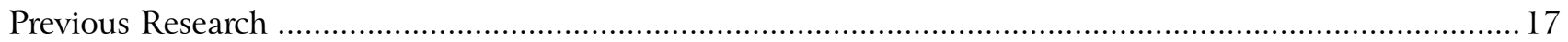

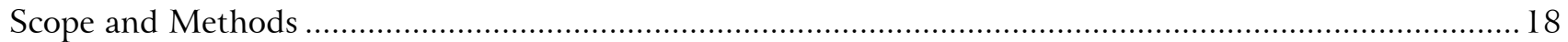

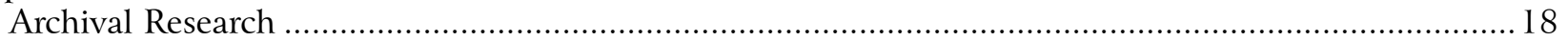

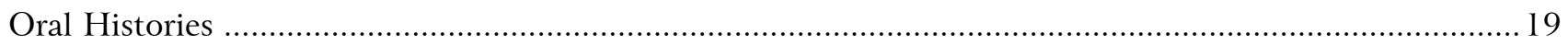

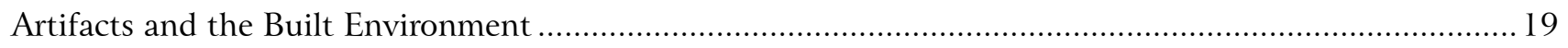

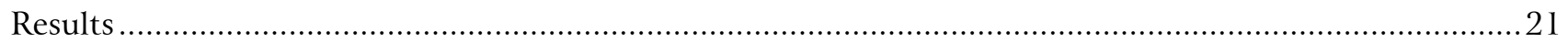

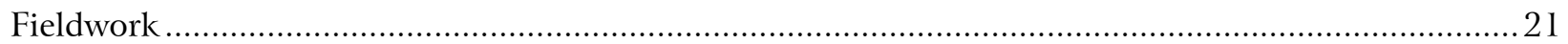

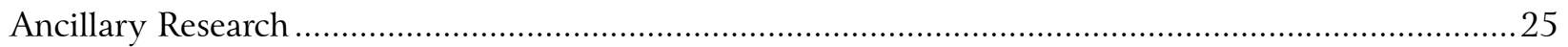

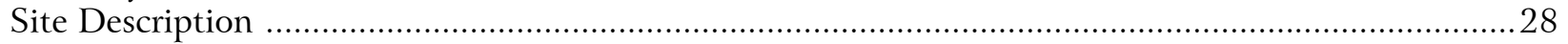

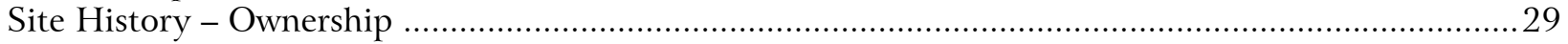

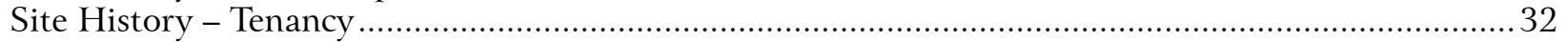

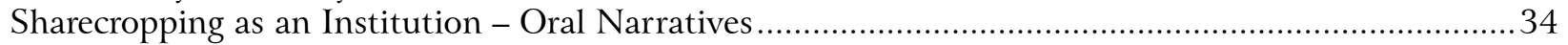

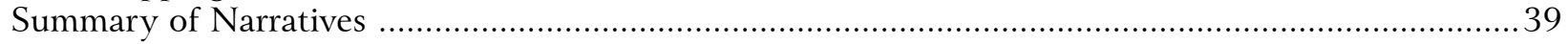

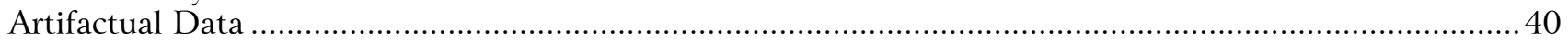

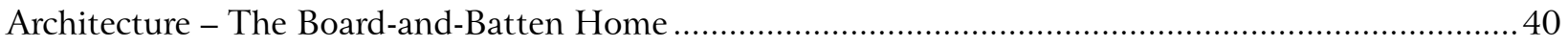

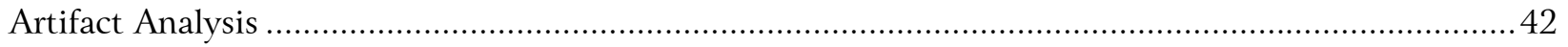

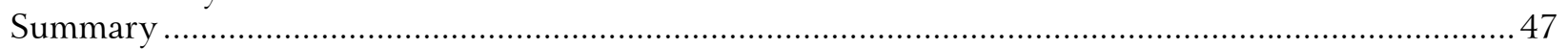

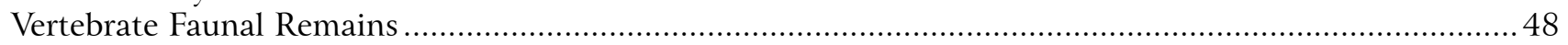

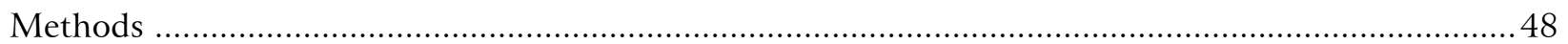

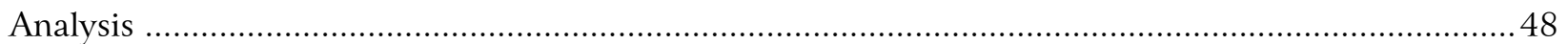

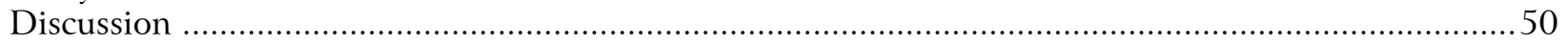

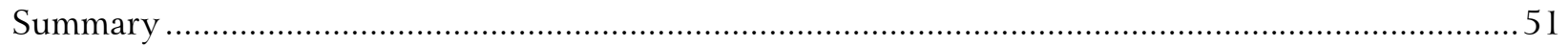

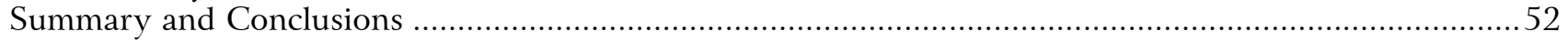

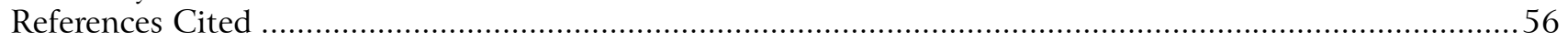

Appendix A

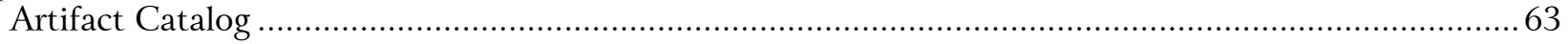

Appendix B

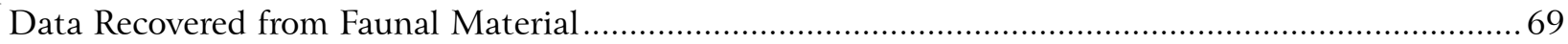




\section{Figures}

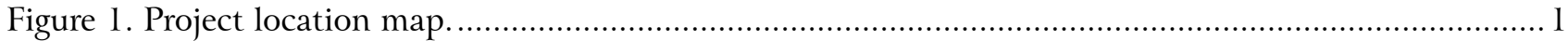

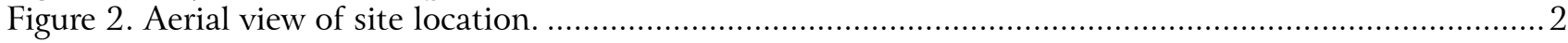

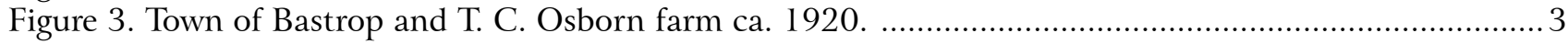

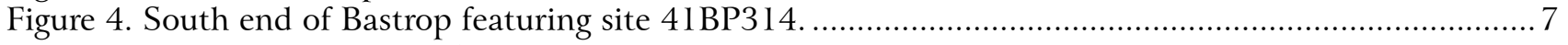

Figure 5. Project area showing features, units, and bladed areas........................................................2

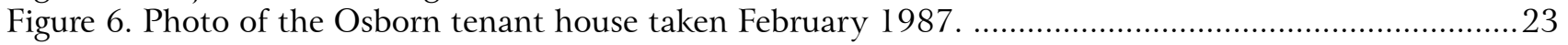

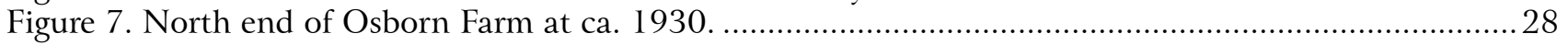

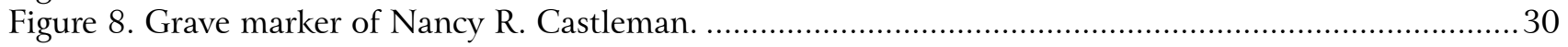

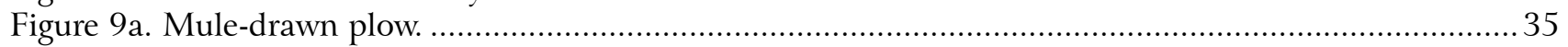

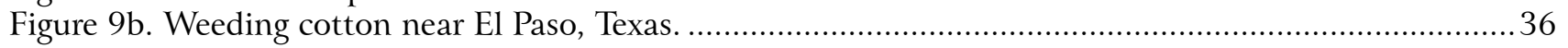

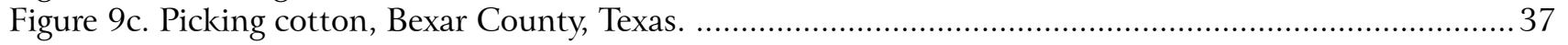

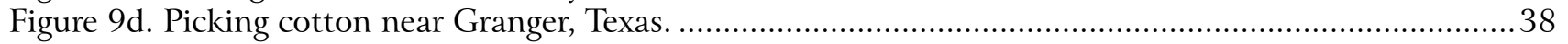

Figure 9e. Cotton wagons on their way to the cotton yard, Elgin, Texas. ................................................ 39

Figure 10. Isometric view of a reconstruction of the T. C. Osborn tenant house. ....................................41

Figure 1 1. South elevation and north elevation of T. C. Osborn house ............................................... 43

Figure 12. West and east elevations of the T. C. Osborn house. …..........................................................4

Figure 13. Samples of activity and personal items recovered from the T. C. Osborn site. .........................45

Figure 14. Samples of assorted buttons recovered from the T. C. Osborn site. .........................................46

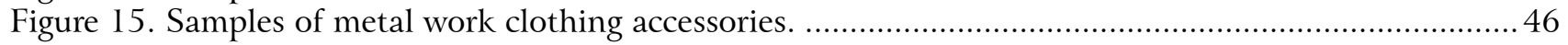

Figure 16. Samples of bottles recovered from the T. C. Osborn site. ......................................................4

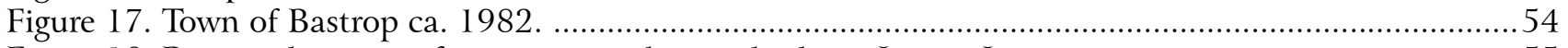

Figure 18. Present-day view of site-view to the south, down Lovers Lane. .............................................55 


\section{Tables}

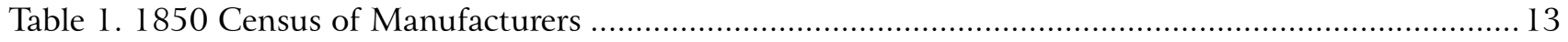

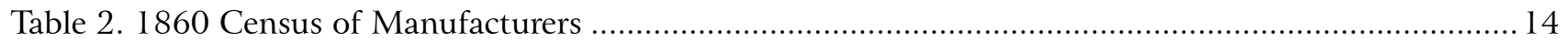

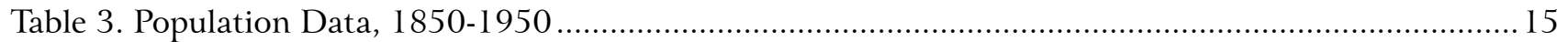

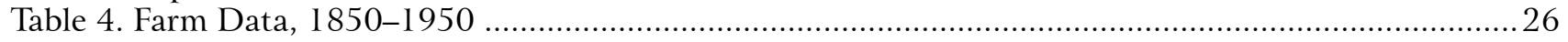

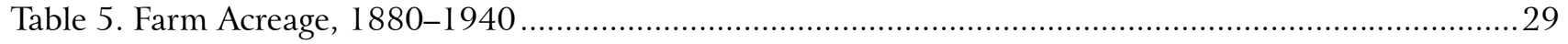

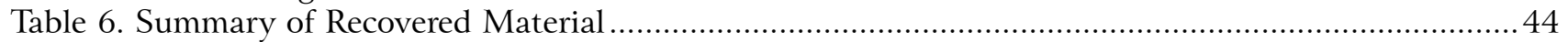

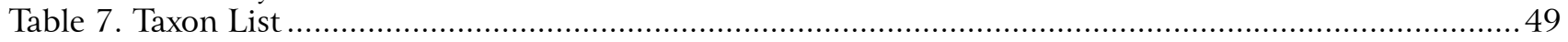

Table 8. Percent of Total NISP Bone Weight for Selected Taxa …..............................................................5 50

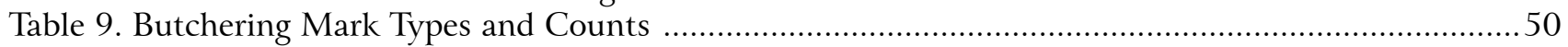

Table 10. Meat Cuts Represented in the Collection, with an Ordinal Scale of Value ..............................5 1

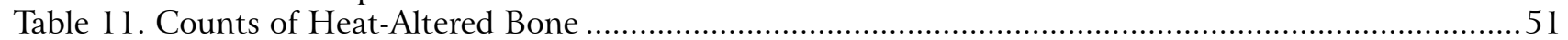

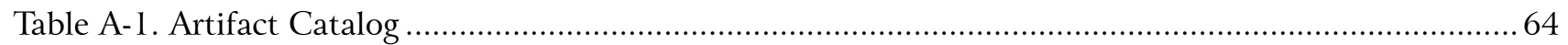

Table B-1. List of Data Recovered from Faunal Material .................................................................... 70 


\section{Acknowledgments}

The author wishes to acknowledge the encouragement and assistance of numerous citizens and public servants of Bastrop. The archival research could not have been accomplished without the assistance and cooperation of Shirley Wilhelm and Rose Pietsch of the County Clerks Office, Bastrop County, and their capable staff. Also lending a hand were Roy Hasty of the Bastrop Central Appraisal District and Mickey DuVall of the Bastrop Public Library. Other members of the Bastrop community who encouraged or assisted the author were Craig Pence, who is restoring the T. C. Osborn family home, Pat Wedding of Bastrop Middle School, and Charles Huth of Ascension Catholic Church. Closer to home, I would like thank Tom Shelton and Kendra Trachta of the Institute of Texan Cultures, The University of Texas at San Antonio, for providing their usual gracious assistance.

A note of thanks is also due the support team at the Center for Archaeological Research. The suggestions and encouragement of Dr. Robert J. Hard, Dr. Steve A. Tomka, Cindy Tennis, and Marybeth Tomka and her capable staff, especially Kristi Miller, were all important to the success of this project. For their assistance and suggestions, thanks are also due to our graphics staff, Bruce Moses and Richard Young, and our editors, Maryanne King, Johanna Hunziker, and Jennifer Logan. For their technical support, thanks are also due to Dr. Nancy Kenmotsu, Barbara Hickman, and G. Lain Ellis of the Environmental Affairs Division, Texas Department of Transportation (TxDOT), as well as Carol Hollingsworth and Cindy Merton of The University of Texas at San Antonio, Office of Grants and Contracts, and lastly, our own administrative support staff comprised of Sherri Suñaz, Mike Wright, and Tammy Hosek.

In addition to being contracted to publish this report, our contract with the Archeological Studies Program, Environmental Affairs Division, TxDOT also called for the development of a "mini-unit plan" that could be incorporated into seventh grade social studies curricula. To accomplish this we solicited the collaboration of our University of Texas colleagues, Dr. Mary S. Black and Dr. Haydeé M. Rodríguez. Doctors Black and Rodríguez are both with the Department of Curriculum and Instruction, College of Education, The University of Texas at Austin. We thank them for their excellent work and collaboration on this project.

We also acknowledge the following individuals that undertook the 1987 fieldwork. The Texas Department of Transportation field crew was led by John W. Clark, who was assisted by Alan Wormser, Tom Eisenhower, Benji May, Jesús González, Charles Washington, Danny Smith, Ken McMullen, Lee Hays, Gary Towns, and David Till.

Many, many thanks are also due Esther Coy of the Bastrop County District Attorney's Office who introduced me to members of the Barrón, García, and Martínez families, and to Dolores Coy Barrón, who provided additional insight. And finally, we acknowledge the wealth of information secured through the personal narratives of Rudy Martínez, José Barrón, and Louise Rodríguez García of Bastrop, Pete Martínez, Jr. of Austin, and Emma Rockwell of West Virginia; thank you all for your time and patience. We can only hope that in some small way this report might pay tribute to yours and your parents' hard work and resolve.

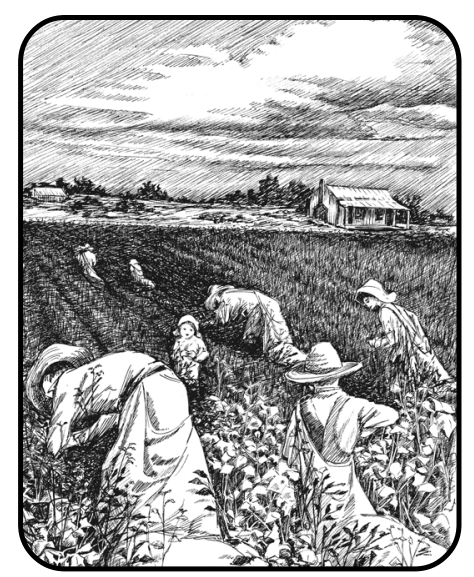

Cover art by Eloy G. Zapata. 

The T. C. Osborn Tenant Farm, 41BP314

\section{Introduction}

In early 1987, the Texas Department of Transportation (TxDOT) performed archaeological excavations and architectural documentation of the T. C. Osborn Tenant Farm (41BP314), Bastrop, Bastrop County, Texas (Figure 1). This work was carried out in advance of the construction of Lovers Lane Road, which would meander through the farmstead, just south of State Highway 71 (Figure 2). Investigations were undertaken due to the determination that the site was eligible for the National Register of Historic Places, and TxDOT's commitment to mitigate the adverse affects of construction on this historic property. The work was carried out in compliance with Texas Antiquities Permit No. 598, and supervised by John W. Clark of TxDOT. The Center for Archaeological Research, The University of Texas at San Antonio, was then contracted to bring this project to closure.

The fieldwork was conducted over a ten-day period, between late-February and early-March 1987. A total of 31 units were excavated and two areas were bladed. Numerous artifacts were recovered, including ceramic sherds, glass fragments, beads and marbles, assorted metal objects, buttons, bone fragments, cut and wire nails, and an assortment of other construction-related material. A portion of the field work included a Historic American Building Survey (HABS), Level 3 documentation. As a result, a series of measured drawings of the demolished four-room board-andbatten home were drafted. The finished drawings are presented in the Results section of this report.

In July 2000, the Center for Archaeological Research, The University of Texas at San Antonio (CAR-UTSA), entered into a contract with TxDOT to prepare a final technical report that would interpret the artifactual, archival, and historical data resulting from, and relating to, the work at site 41BP314. The required work included a graphic and textual representation of the board-and-batten home. The final report was used in the development of a five-day curriculum plan for seventh-grade history classes, which is submitted separately.

Based on preliminary data recovered in 1987 , the boardand-batten home was said to have been constructed ca. 1906 and occupied by tenant farmers until ca. 1930. This initial information suggested that the Pedro Martínez family occupied this site between ca. 1906 and 1925. This same family occupied the nearby G. W. Jones house, a two-story ca. 1855 structure, between ca. 1925 and 1952 (Robinson 1989).
Although not precise, this preliminary data was very useful in locating members of the Martínez family, as well as other significant players. These persons were then interviewed using a protocol that emphasized the temporal and spatial use of the site.

More recent data indicates that the board-and-batten house was in fact home to at least two families. A member of one of these families still resides within four blocks of the original site and was interviewed for this project. Combined with the architectural survey, excavated material, and archival research, oral histories serve to reconstruct the life of this site - the land, material culture, and the people.

The Osborn Farm comprised 327 acres of fertile bottomland located along the southern limits of the town of Bastrop and to the immediate east of the Colorado River and Gills Branch Creek (Figure 3). The farm was established ca. 1840 by Andrew Ewing Castleman, during the Republic of Texas era. Between ca. 1906 and 1954, approximately 100 acres of the farm were cultivated in cotton, with the remainder used for grazing and homesteads. The tenant house site

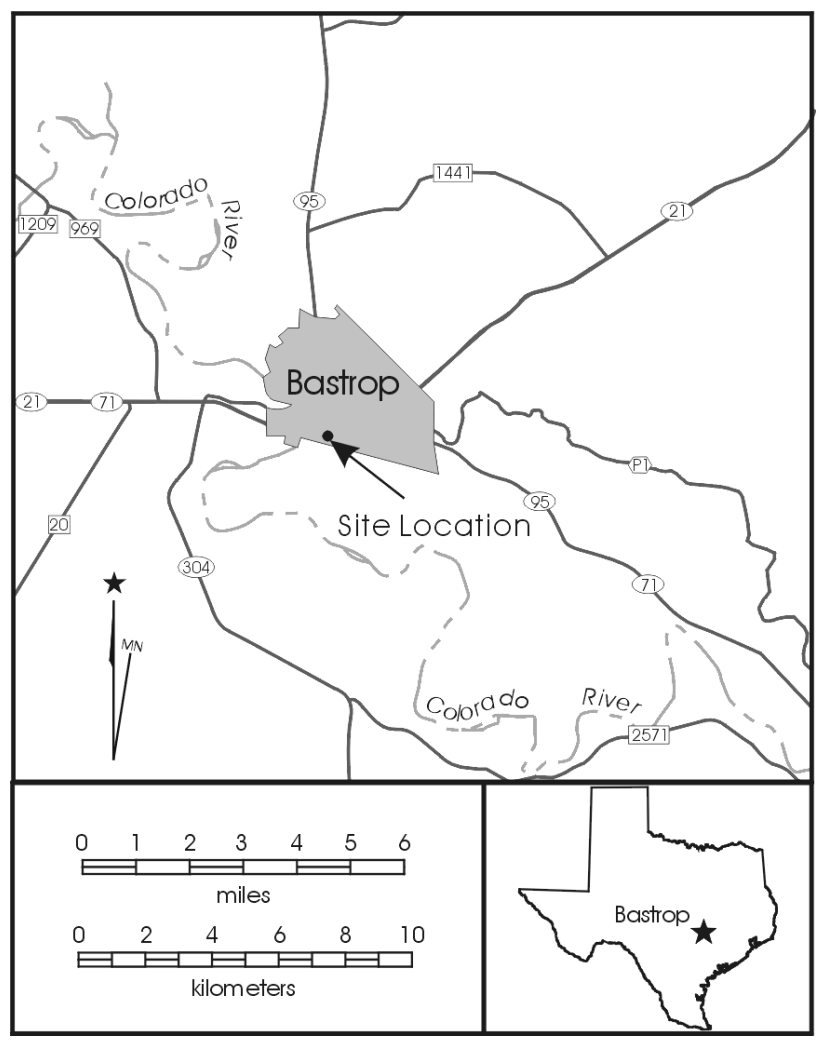

Figure 1. Project location map. 


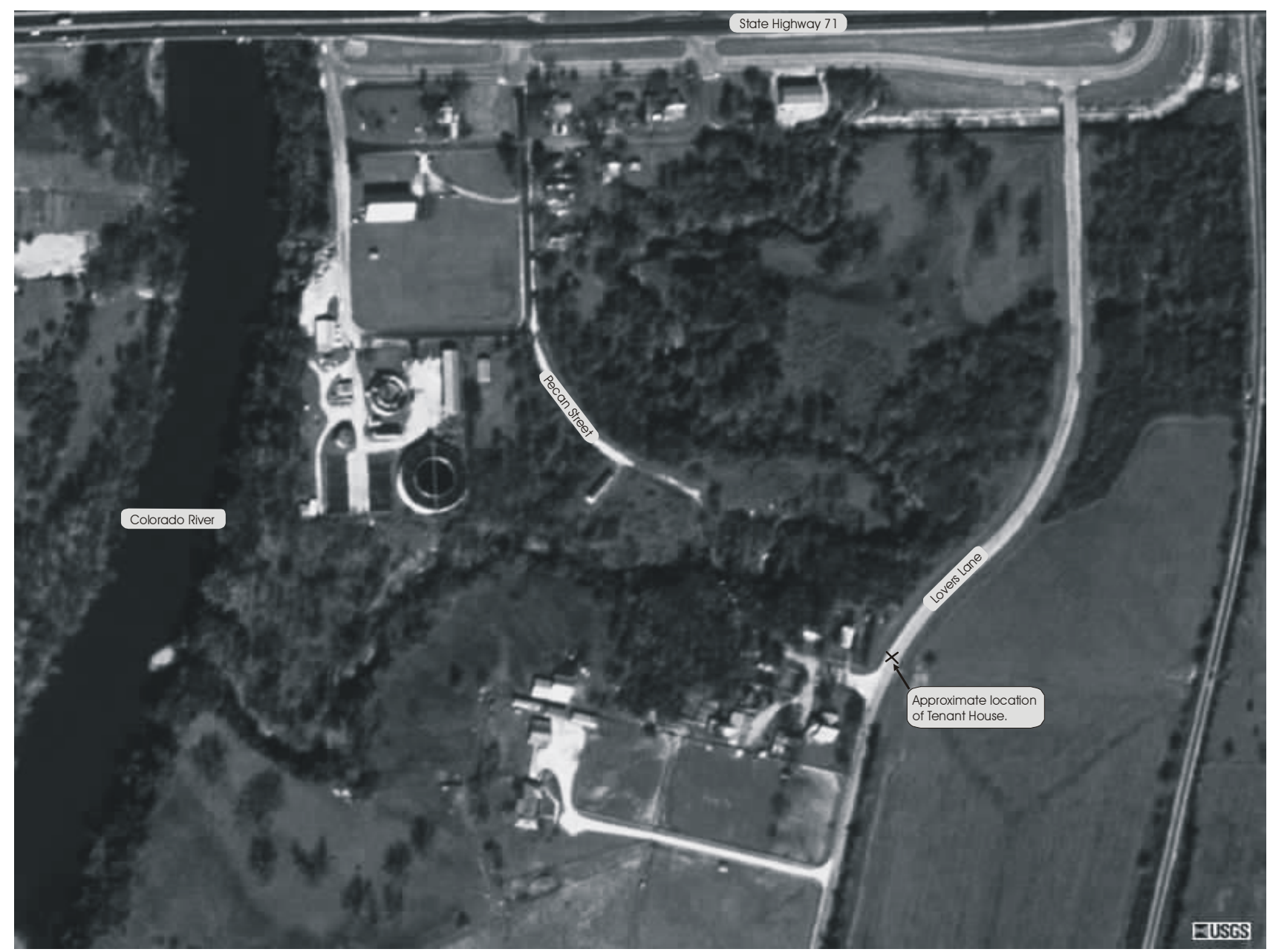

Figure 2. Aerial view of site location. (From MSN TerraServer ${ }^{\circ}$ )

(41BP314) was situated along the extreme northwest end of the tract, and is labeled No. 1 in Figure 3. This same figure also shows the location of the G. W. Jones site (41BP86), labeled No. 2, which served as the farm's main house. By as late as 1989, there were two log cabins located within the vicinity of the main house that had served as slave quarters between 1840 and 1865 . These were later used as tenant housing. The farm's barn and corral, labeled No. 4, are shown to the immediate east of the main house. Also shown is an additional tenant house (No. 3), which was in use by as early as 1917 . None of these features remain. 


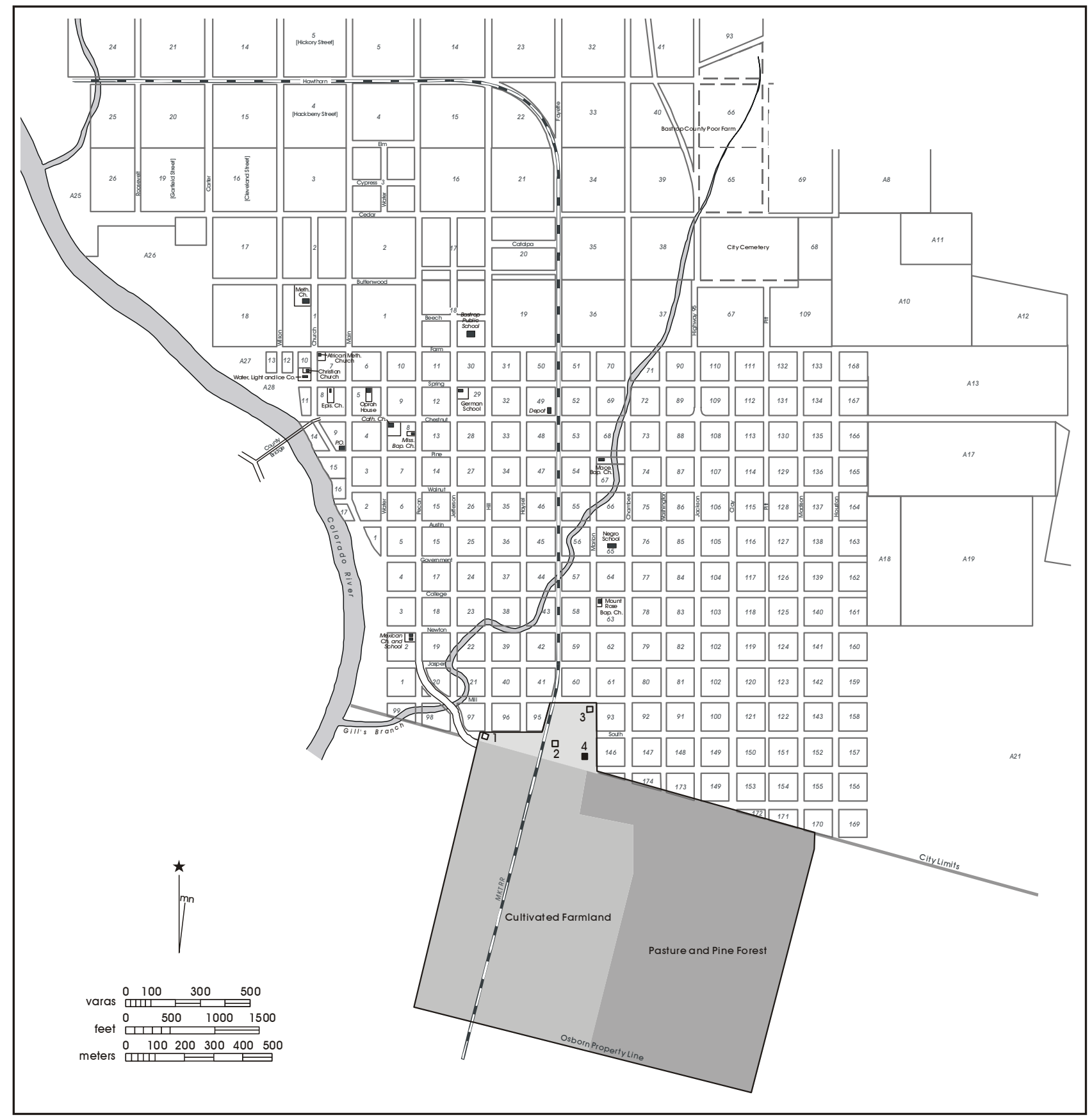

Figure 3. Town of Bastrop and T. C. Osborn farm ca. 1920. 


\section{Research Design}

The objective of this study was to place the T. C. Osborn Farm site in historical context and to highlight the growth of cotton farming and the contributions of Mexican farm workers in central Texas from 1900 to 1950 . Among the major topics to be considered are the geographic, economic, demographic, and social developments in Texas during the early-twentieth century. A total of three research questions were pursued; these relate to issues of migration, community evolution, and site utilization. At this point, the story of this seemingly insignificant farm spans no less than 125 years, and involves no less than six families.

As far as can be determined, this is the first archaeological study in Texas that features a tenant farm site occupied by a Mexican family. Issues such as those relating to immigration patterns, race and ethnic relations, labor relations, economic development, settlement patterns, etc., have been addressed in the labor history studies of Gómez-Quiñones (1994) and Zamora (1993), and the social history studies of García (1996) and Montejano (1987). We will be using the results of these studies as contextual framework regarding the Mexican tenant farmer experience. We propose to pursue two issues which will maximize the use of the available data and which can be accomplished with a reasonable level of effort. The two issues are: 1) Mexican immigration patterns, and 2) social and economic relationships within an early twentieth-century rural community.

\section{Mexican Migration Patterns into Central Texas}

About a half million Mexicans immigrated to the U.S. during the first three decades of the twentieth century. This migration continues unabated today (Maldonado 1985; Montejano 1987). Most of these Mexican immigrants took jobs on farms, railroads, and in urban-based low-wage industries (Zamora 1993). Social scientists have modeled the immigrant process with a variety of models that specify both the "push" forces that encourage populations to migrate and the "pull" forces that encourage people to settle in a particular location. Both push and pull factors need to be considered to understand a particular migration pattern. Hall and Coerver (1988) suggest that the Mexican Revolution period (1910-1920) marked the beginning of modern migration patterns. The violence, ensuing social and economic upheavals, and loss of farmlands and employment caused by the Mexican Revolution pushed many families to the north in search of better livelihoods. Gómez-Quiñones (1994) contends that a pull exerted by U.S. capitalist demand for labor accelerated this mass migration. This demand was generated by U.S. prosperity and industrialization of the early 1900s, and a ready labor surplus created by Mexico's internal strife. The work force of northern Mexico served as a reserve pool of labor that met the fluctuating needs of Texas industries, especially agriculture (Zamora 1993).

Given this context, the current study considered whether the Martínez family's experience is consistent with that of the typical migrant farm worker. According to Zamora (1993), until 1915 the vast majority of immigrants chose Texas as their preferred point of destination and many converged in San Antonio. Between 50 and 75 percent of these immigrants returned to Mexico on a yearly basis. While acknowledging the social and regional diversity of the early-twentieth century Mexican immigrant, GómezQuiñones (1994) suggests that the Mexican immigrants did share five basic characteristics. The Mexican immigrant: 1) emigrated due to lack of work and low wages; 2) alleged a strong desire to eventually return to Mexico; 3 ) expressed a dissatisfaction with their status at home and a desire to change it; 4) in comparison with other immigrants, the Mexican immigrant was younger and less skilled, with both sexes immigrating; and 5) usually had relatives in the U.S. who were also immigrants and with whom they retained family ties.

The social and economic context of Mexican migration and the typical characteristics of the migrant workers provide a framework in which to place the Martínez family. By examining the Martínez family's history and comparing it to these characteristics, we should be able to identify the typical or atypical nature of this family's immigration and settlement story.

\section{Social Relations within an Early Twentieth Century Rural Community}

During the early-twentieth century, a little over 70 percent of the legal (i.e., documented) immigrants expressed their intent to settle in Texas. Most were bound for San Antonio or other Texas communities with sizeable Mexican populations (Hall and Coerver 1988). However, by ca. 1910, the Cotton Belt area rivaled the Rio Grande border region in the number of permanent Mexican residents, despite the fact that a significant number returned to Mexico annually. This return migration reinforced a pattern of cultural and political interaction between communities on both sides of the border (Zamora 1993). 
As Mexicans were pushed out of their homeland, they were pulled to particular locations by social and economic conditions that had more favorable prospects. Frequently, an immigrant selected a location based on the presence of a social support network that consisted of relatives but also included friends, or other social groups that assisted in finding work and housing, protection from illness, and assistance with burials. García (1996) contends that the typical Mexican migrant was particularly concerned about dying and being buried in a strange land far from family and friends. During the earlytwentieth century, as large Mexican communities became established in the U.S., they actively formed permanent support networks for the newly arrived, including: mutual aid societies, social clubs, and sports teams (García 1996). Such relationships established cycles of donor and recipient communities such that migrants from a particular part of Mexico tended to migrate to a particular area of the U.S. The formation and nature of these networks are fundamental to understanding how migrant communities become established and maintain themselves.

García (1996), in Mexicans in the Midwest: 1900-1932, documents a unique type of these migrant communities in the Midwest. Mutual aid societies rapidly and energetically formed in Kansas City. The Midwest was a far more geographically and culturally isolated location for Mexican immigrants than the border states. In addition, some of the earliest immigrants to Kansas City were upper class professional Mexicans such as doctors, lawyers, and engineers who had escaped the political and economic persecution of the Mexican Revolution. These elite Mexicans played a key leadership role in organizing self-help societies based on the nationalistic impulses of both upper and lower class Mexican citizens. They were intent on portraying the positive attributes of their citizenry to combat prejudicial attitudes towards Mexicans by Anglo Midwesterners. These social groups also had the intent of maintaining the Mexican cultural identity and resisting acculturation into the larger Anglo society (García 1996).

We know of no analogous documentation of mutual-aid societies in rural central Texas. Nonetheless, Mexican immigrants settled in numerous rural towns across south Texas, as well as central Texas towns such as Bastrop. This phenomenal growth also brought with it the development of distinct Mexican and Anglo neighborhoods and the establishment of hierarchical social and economic relationships with the existing Anglo communities. The Midwest study provides a number of useful points of contrast for analyzing the Bastrop setting in our attempt to document the nature of the immigrant community's social networks and their role in attracting, or pulling, Mexicans to this community. Specifically, we will examine three issues: 1) What was the nature of the Mexican community's social network in Bastrop? 2) What role did these networks play in attracting Mexican immigrants to Bastrop, particularly with regard to the Martínez family? and 3) How did such social networks originate? This analysis of the Bastrop Mexican community's social network will also be placed within the context of the larger Bastrop community.

In the south Texas farm communities discussed by Montejano (1987), the constituents of early-1900 farm communities could be classified according to three general categories: Anglo farm owners; Anglo and Mexican tenant farmers; and Mexican farm laborers. The tenant farmer category was actually comprised of two subcategories - share tenant and sharecropper. Montejano defines the "share tenant" as a family, typically Anglo, that rented a plot of land and house in-lieu of one-third of the grain and one-fourth of the cotton harvest. In contrast, the "sharecropper" was a family, typically Mexican, that was allowed to keep half of the cotton harvested on the assigned acreage. Most often, the assigned acreage for a share tenant amounted to 30 acres per plow-hand, and only 15 acres per plow-hand for sharecroppers (Montejano 1987:170-173).

\section{Research Summary}

The preliminary data indicates that the Martínez family obtained a tenant farm. Curiously, Montejano (1987) has suggested that Mexicans were typically not assigned to this position. His study focused on south Texas, but he suggested it was also applicable to portions of central Texas. This apparently paradoxical farm tenancy at $41 \mathrm{BP} 314$ raises provocative questions. Was this rise of the Martínez' due to particular conditions relating to the Osborn farm and this family, or were the social, economic and ethnic processes different in this part of central Texas? The key word here is typical, and it may be that this family is an exception to Montejano's model.

In addition to the possibility that the Martínez experience represents individual, rather than regional variation, we have two alternative hypotheses. The first is that the Mexicans' relative position in the social and economic hierarchy in the Bastrop region was pushed upward by the documented presence of higher proportions of African Americans. 
Did African Americans replace Mexicans on the lowest economic rung, allowing Mexicans to occupy the middle position below Anglos yet above African Americans? If this were the case, it would have afforded Mexicans more economic options, including that of tenant farming.

An alternative possibility is that the numerous Germans in the Bastrop region were more tolerant of other ethnic groups. The Germans, as recent immigrants from a more multicultural Europe, may have been more accepting of nonWhites and more sympathetic to other immigrants. We know for example, that German neighborhoods in San Antonio tended to be less segregated than other San Antonio Anglo neighborhoods (Fox et al. 1997). Finally, if the Martínez' gain of farm tenancy is unusual in the Bastrop community, as it would have been in south Texas, then we will attempt to discern the individual characteristics of the Martínez and Osborn families that would explain this exception to the regional pattern.

This dual examination of the social, political, and economic structure will focus on the attractiveness of the Bastrop community to Mexican immigrants and will be conducted at two levels: the social matrix of the local Mexican community and the larger agricultural community of Bastrop within which the immigrant Mexicans were situated. The Martínez family will be the nexus of this examination in that we will attempt to discern how they interacted with the Mexican community, as well as the larger Bastrop community. We will seek to establish the social and economic matrix within which they existed and the nature and proximity of their affiliations and interactions. For example, did they maintain a strong identity and relationships with particular aspects of the Mexican community, or did their somewhat more elevated economic condition bring them in closer alliance with the Anglo community and the Osborn family, or did they seek to maintain an identity with multiple communities? 


\section{Natural Setting}

Bastrop County is located in south-central Texas, and is bordered by the counties of Williamson, Lee, Fayette, Caldwell, and Travis. The county is 891 square miles in size, or 570,240 acres. The city of Bastrop, located about 30 miles to the southeast of Austin, is situated in the center of the county and serves as the county seat. The Colorado River meanders through the county in a southeasterly direction, and within $1,300 \mathrm{ft}$. $(396 \mathrm{~m})$ of the Osborn site (41BP314).

The countryside is characterized by rolling uplands and broken hills and exhibits a noticeable variation of being nearly flat to hilly. The elevation ranges from between 270 and $687 \mathrm{ft}$. above sea level, in the Smithville and McDade areas, respectively. The county's main sources of income are derived from farming and ranching. Approximately 22 percent of the land is used for crops (mainly cotton and grain sorghum), 25 percent for pasture (beef cattle), and 36 percent is forested, with most of the forested areas being used for pasture and recreation (Baker 1979; Handbook of Texas Online 2000; Moore 1977).

Bastrop County is situated on the Texas Gulf Coastal Plains and is affected by the Post Oak Belt and the Blackland Belt. Two plant life regions abound in this county: the Secondary Forests and Woodlands comprised of blackjack oak, elm, and pecan, as well as an isolated pocket of forest known as the "Lost Pines." This forest is very unusual because this section of loblolly pines appears some eighty miles beyond the western limit of the main pine belt in Texas. The second region is the Blackland Prairie, which is present only in the far northwest portion of the county.

The city of Bastrop is situated at approximately $374 \mathrm{ft}$. above sea level. The core of the town is bounded by the
Colorado River on the west, Piney Creek on the north, the headwaters of Coopers Creek on the east, and Gills Branch Creek on the south. At the city's eastern edge stands an isolated pocket of "Lost Pines." Bastrop is located at the edge of three major ecological areas, the Balcones Hill Country, the Blackland Prairie, and the Piney Woods. The town's location provided access to lumber, stone, and clay resources, numerous wild game, and an ample supply of water (Texas Historic Site Atlas 2000).

The Osborn Farm site (41BP314), located along the river valley (Figure 4), is situated at approximately $360 \mathrm{ft}$. above sea level and lies within the Bosque-Smithville-Norwood soil association. These are nearly level soils that have a loamy surface layer and moderately permeable lower layers. This soil association is found in a long, narrow area along the Colorado River. The soils of the study area are of the Smithville series, which exhibit a surface layer of grayish-brown, fine sandy loam (0-6 in.) over a layer of dark grayish-brown loam (6-16 in.). The lower layers, deeper

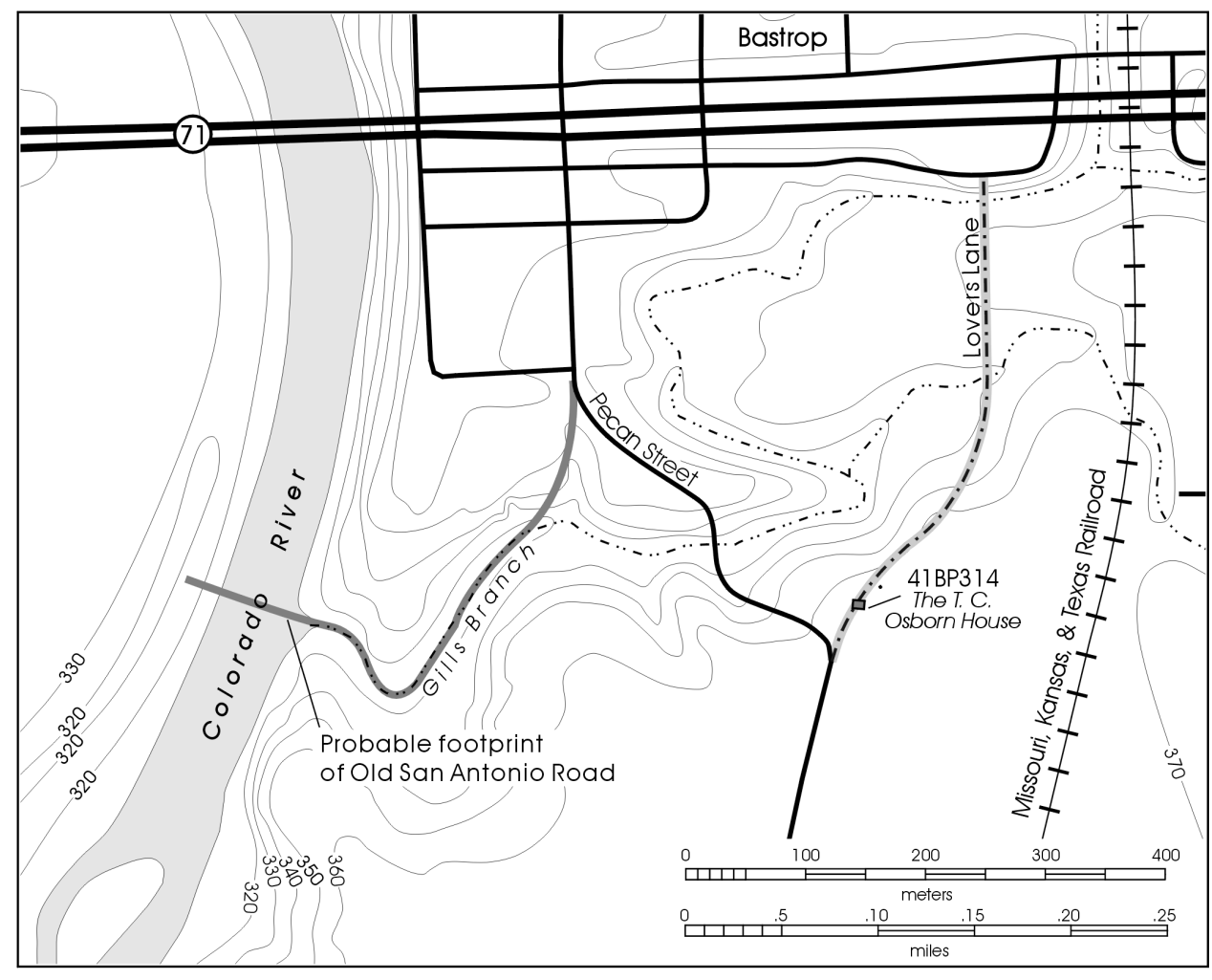

Figure 4. South end of Bastrop featuring site 41BP314, the Colorado River, and Gills Branch Creek. 
than 16 in. below surface, are a reddish-brown to reddishyellow sandy clay loam (Baker 1979; Handbook of Texas Online 2000; Moore 1977).

The county's annual average temperature is $68^{\circ} \mathrm{F}\left(20^{\circ} \mathrm{C}\right)$, with a mean minimum of $40^{\circ} \mathrm{F}\left(4^{\circ} \mathrm{C}\right)$ in January and a mean high of $96^{\circ} \mathrm{F}\left(35^{\circ} \mathrm{C}\right)$ in July. The annual average rainfall is 36 in. $(91 \mathrm{~cm})$. These favorable temperatures and rainfall rates provide for a generous growing season of 268 days. The prevailing winds are from the southeast (Lower Colorado River Authority 2000; Moore 1977).

The city of Bastrop presently relies on a variety of economic resources. Besides cotton, sorghum, and beef, mentioned above, other important products include hay, oats, peaches, pecans, pine timber, watermelons, and livestock. The city also relies on a good variety of natural resources, such as clay, coal, sand, gravel, gas, and oil, as well as surface and underground water (Lower Colorado River Authority 2000). The area's historical architecture, numerous landmarks, and attractive natural setting are also important commodities, since they lend themselves well to the development of tourism and recreation. 


\section{Historical Background}

\section{Introductory Note}

Numerous owners and tenants make up the history if this seemingly insignificant site, and more may surface. Although we will elaborate on these in the Results section of this report, we find it sensible to include some introductory notes at this time.

Among the more notable owners of the site were Andrew Ewing Castleman, George Washington Jones, and Thomas Claiborne Osborn. The residents of the site included the tenant farm families of Livorio González, David García, José Barrón, and Pedro Martínez. The first two owner-operators of the farm, Castleman and Jones, although of minimal interest to this study, are helpful in developing and presenting the county's history and the development of cotton farming in the area. The third, a nonresident-owner, Thomas Claiborne Osborn, is the most important since he was the one that developed the northwest section of the farm in order to accommodate tenant families during the period of interest.

As for the tenant families, Livorio González was probably among the first to reside at 41BP314, followed by an unknown tenant and then by the family of David García. Two García family members proved extremely important to this study, as they were able to provide us with a glimpse of what it was like living and working on the Osborn Farm. One of these was Louise García, the 94 year-old widow of David García, and the other was their daughter Emma Rockwell, nee García. Although not directly involved in the Osborn Farm, José Barrón provided some very important background information regarding tenant farming and tenant families. Finally, the person most responsible for helping us sort through the site's history and occupancy was Pete Martínez, Jr. The Martínez family name has already been introduced several times, and as briefly mentioned, this family never actually resided in the board-and-batten house (41BP314). However, as will be demonstrated below, the Martínez family did play a very prominent role in the history of the Osborn Tenant Farm.

\section{Early History}

Given the rich natural resources, it is no wonder that this area's cultural history is centuries old. Whether nomadic or semisedentary, numerous indigenous groups utilized the abundant native resources. Over the ages, the forceful displacement of one group over another was common. The historical records indicate that among the Native Americans of Bastrop County were the Comanche, Lipan Apache, and Tonkawa, who had over the years themselves migrated south and west into this area. The Comanche were the latest to arrive and by the early1800s they had driven the Lipan Apache and Tonkawa from their homes along the Great Plains. As a result, the Lipan Apache and Tonkawa often allied themselves with the Anglo settlers on punitive expeditions against the Comanche. Stephen F. Austin's colonists benefited considerably as a result of their alliance with the Tonkawa who, over the years, remained staunch allies of the settlers (Handbook of Texas Online 2000; Kesselus 1986).

The first recorded expedition into Bastrop County was by the Spanish. In 1691, Don Domingo Teran de los Ríos and Fr. Damian Massanet led an expedition into this area in order to find a more direct route to the newly established Mission San Francisco de los Tejas in East Texas (Moore 1977). The expedition left Mexico City on May 16, 1691 and reached the Colorado River, near present-day Bastrop County, on June 26, 1691. This early attempt to cut through the area of Bastrop County and the great pine forest failed. It wasn't until September 1795 that the Spaniards finally managed to successfully cut a road from San Antonio to present-day Bastrop and on into East Texas. This was known as Camino de Nacogdoches (Road to Nacogdoches) and was later simply referred to as the Old San Antonio Road. In Texas, the road commenced at Laredo, then headed towards San Antonio, then on to present-day Bastrop, and finally ended at Nacogdoches (Kesselus 1986).

The next mention of any activity in this area occurs in the early-1800s, with the establishment of a small military post at the above noted crossing. The post was known as Puesto del Colorado (Post on the Colorado) and was established in order to protect trade and travel along the King's Highway. In 1807, Zebulon Pike made note of this small settlement while surveying the countryside on behalf of the U.S. government. According to Pike, the post was garrisoned by a small detachment of Spanish Dragoons and was bordered by a settlement of Tonkawas (Moore 1977).

Based on reconstructed accounts and old maps, the Old San Antonio Road is said to have crossed the Colorado River about 100 varas (277 ft.) above the Gills Branch Creek. The road approached the river crossing from the northwest, cut across to the southeast, crossed the river, then turned north along the path of what would later become Pecan Street, and then cut east along Chestnut, then a short distance north along Hill, and finally northeasterly towards 
Hoffman Road and a small path along the pine hills (Kesselus 1986:20-21). According to McGraw et al. (1998:221), this crossing was located at Gills Branch Creek as it was approached from the west. The Old San Antonio Road would then meander up and along the Gills Branch Creek, onto Pecan Street, and then east along the present-day path of State Highway 21 (Figure 4).

\section{Anglo-American Settlement}

In 1805, fearing American encroachment into Spanish territories, Governor Cordero of the Province of Texas proposed that villas be founded on the Colorado, San Marcos, and the Guadalupe rivers at points where the road to Nacogdoches intersected these rivers (Kesselus 1986). Owing mostly to the fact that the area was vulnerable to attacks by Native Americans, not much came from Governor Cordero's proposal. A small colony of approximately 80 people was established along the San Marcos River in early 1808, but abandoned in 1812 due to continual Native American depredations. In 1829 there were only two towns in all of Texas that were located north of the Nueces River; these were San Antonio and La Bahía (present-day Goliad) (Kesselus 1986).

By 1820 , the colonization of the area that would later be known as Texas was successfully pushed forward as a result of three factors. The first of these was the failure of the government of New Spain to persuade additional Spanish immigration into Texas. At the time, the settlements in San Antonio and La Bahía were only marginally successful. The same was true of the Escandón colonies south of the Nueces River and, at that time, within the boundaries of Tamaulipas. The second factor was the 1819 treaty between the U.S. and Spain, which finally fixed the Texas-Louisiana border at the Sabine River. Convinced that American settlers would eventually make their way into Texas, the government of New Spain was agreeable to controlled immigration initiatives. The third, and probably the most important factor, was the Panic of 1819 that brought financial ruin to many Americans. This financial crisis drove many such as Moses Austin toward a westward migration, and the prospect of starting over. Moses Austin recognized New Spain's predicament and the potential of earning a fortune by mediating the colonization of Texas.

Already having honed his entrepreneurial skills in Pennsylvania, Virginia, and Missouri, Moses Austin traveled to San
Antonio in December 1820, and with the aid of Baron de Bastrop, a politically- and socially-connected friend, he successfully secured a colonization grant. Moses Austin died in Missouri in 1821, while preparing to move the first of the colonists to Texas. His 27 year-old son, Stephen F. Austin, then took over his father's enterprise. Stephen F. Austin was reluctant to assume his father's business venture, but did so nevertheless. He traveled to San Antonio and arrived there in August 1821, and managed to convince the authorities that he could successfully fulfill his father's obligations.

Over the next 15 years, Stephen F. Austin worked tirelessly to negotiate the colonization of Texas. His task was not made easy, given Mexico's independence from Spain in 1821 and the country's ensuing political instability. By 1830, Mexico's internal strife was aggravated by growing tensions in Texas. Cultural, political, and religious differences served to heighten difficulties between the Anglo-American settlers and the Mexican government. Because most of Austin's colonists hailed from Southern states and were disposed to using free labor, Mexico's laws prohibiting slavery became a critical issue. The totality of the assorted difficulties finally led to rebellion, Texas Independence in 1836, and U.S. annexation in 1845 .

As a result of the difficulties noted above, Stephen F. Austin spent the first four years (1821-1825) renegotiating the terms of the colonization agreements. In March 1825 the governments of Coahuila and Texas finally ratified most of the stipulations of the 1821 agreement. The revised law continued the empresario (colonization representative) system and offered each head of household a league of land (4,428 acres), at a cost of thirty dollars to be paid within six years (Kennedy and Kennedy 1987). As an empresario, Austin's responsibility was extremely demanding and he took it quite seriously. Aside from his role as colonization advocate and political emissary, Austin was also involved in the selective recruitment of colonists, directing land surveys, allocating land grants, preparing titles, and leading campaigns against hostile Native Americans.

Although there were other empresarios involved in the colonization of Texas, most would agree that Austin's passion and commitment was unequaled. The once reluctant entrepreneur managed to earn the respect and loyalty of many on both sides of the border. In July 1836, six months before his death, Austin wrote "The prosperity of Texas has been the object of my labors, the idol of my existence- it has 
assumed the character of a religion, for the guidance of my thoughts and actions, for fifteen years" (Handbook of Texas Online 2000).

\section{Development of Bastrop}

Stephen F. Austin established three colonies. The first two were located south of the Old San Antonio Road, and the third was located east of the Colorado River and north of the same road. This third colony, often referred to as the "Little Colony," is of specific interest since it was located within the area of present-day Bastrop (Handbook of Texas Online 2000; Kesselus 1986; Moore 1977). The contract for the "Little Colony" was signed almost 175 years ago, on November 20,1827. Austin was extremely cautious in his selection of those who settled in this colony, and let out 61 contracts and a total of $49 \frac{1}{2} / 2$ leagues of land $(219,186$ acres) (Kennedy and Kennedy 1987; Moore 1977).

Among those granted land in the "Little Colony" was Benjamin Osborn. The contract of 1827 granted him one league (4,428 acres) located along Wilbarger Creek, which joined the tracts of Wells and Duty. Osborn and his wife Leah Stark, who were originally from South Carolina, settled in Tennessee, then in Mississippi, and finally Texas. Both died of yellow fever at Matagorda, leaving their six children orphaned and in the care of friends (Handbook of Texas Online 2000). As empresario of the "Little Colony," and as partial payment for his services to the government, Stephen F. Austin received title to two headrights along the Colorado River. One of these was located to the immediate north of presentday Bastrop and the other was located at the south-end of town. Ownership of a portion of this latter tract would, by the early 1900s, go to the grandson of the above noted Benjamin Osborn. As demonstrated in the Site History section of this report, Benjamin Osborn's offspring figured prominently in the history of Bastrop.

Edward and Sara Jenkins were among the early settlers of the "Little Colony." In 1830, they settled their family on their league located along the west side of the Colorado River. Josiah Wilbarger and Margaret Barker Wilbarger also settled on their league ca. 1830. Their league was located about 12 miles north of Bastrop beside a rather long river bend that bears their name (Kesselus 1986). These early settlers were followed in greater numbers between 1830 and 1832. In 1832, the heirs of Benjamin Osborn assumed title to his tract and the oldest of his children, 24-year-old John
Lyle, then built a log cabin and settled with his brothers and sisters on their league (Handbook of Texas Online 2000; Mary Belle Turner Gore to Craig Pence, letter, 24 May 1979, Pence Collection, Bastrop, Bastrop County, Texas; Moore 1977:29-32).

Between 1831 and 1832, the appointed land commissioner from San Antonio, Miguel Arciniega, formalized 50 land grants. In June 1832, Arciniega authorized a four-league tract for the Town of Bastrop. Even though the grant called for a plaza (public square), this Spanish colonial-style town square was never formalized (Kesselus 1986:102-103). Instead, the town took on an Old-South character, and the allotted public square block (block no. 7 in Figure 3), was later used as the site of the present-day County Courthouse and Annex (jail). The town continued a slow and steady growth between 1832 and 1836, and then faltered as a consequence of the Texas revolt against Mexico.

In March of 1836, after the fall of the Alamo and in fear of advancing Mexican troops, the 400-odd settlers of Bastrop withdrew up the Old San Antonio Road towards Louisiana. Many of these families were still crossing the Trinity River when they received word of Santa Anna's defeat at San Jacinto. Although many of the families ceased their retreat and returned home, other families preferred not to and resettled elsewhere. Upon returning, the settlers found their homes ransacked and/or destroyed, and their livestock missing. To make matters worse, Native American depredations over the next two to three years were especially harsh and, up until about 1839, Bastrop County was considered a depopulated county. A good example of such depredations is the scalping of young Claiborne Osborn. In 1840, the 14 year-old son of Benjamin Osborn was attacked and scalped while guarding the pack animals of a hunting party he was with. Osborn survived the attack; he later married Almira Jane Leverett, fathered 10 children, and lived to the age of 72 . Native American depredations continued for several more years, but were almost nonexistent by late 1845 (Kesselus 1986; Mary Belle Turner Gore to Craig Pence, letter, 24 May 1979, Pence Collection, Bastrop, Bastrop County, Texas).

Bastrop County was one of the ten original counties created in 1836 by the First Congress of the Republic of Texas. For a few years prior, the parent county had been the Municipality of Mina (Kennedy and Kennedy 1987). The county's area at this early date was much larger and, after several counties were created, finally assumed its present size in 
1874. The town of Bastrop was incorporated under the laws of the Republic of Texas on December 18, 1837. Between 1837 and 1839, Bastrop was in serious contention to be designated the state capital. Even though they failed to secure this designation, and as a direct result of the positive inroads made with regards to town planning, Bastrop's economic development increased dramatically between 1839 and 1842. During this period, Bastrop was home to eight general stores, two hotels, seven saw mills, two cotton gins, and a coal mine. The town also had two attorneys, a doctor, lumberyard, livery stable, and a river ferry at the foot of present-day Chestnut Street (Kesselus 1986). However, this economic prosperity was short-lived, and an economic depression hit Texas from 1842 to 1845.

In mid-1842, in response to a possible invasion by Mexican troops, President Houston relocated the new republic's government to Houston and then to Washington-on-the-Brazos. Since Bastrop's economic prosperity was closely linked to nearby Austin's, the transfer of the seat of government caused the economy of both towns to suffer. These conditions were aggravated throughout the Republic period by bad crops, a rash of runaway slaves, and a shortage of paper money. Bartering was especially popular during this depression, and land became a common means of exchange. With the annexation of Texas by the U.S. on March 3, 1845, the possibility of a new start was once again insured (Kesselus 1986).

Throughout the last-half of the nineteenth century, the town of Bastrop enjoyed a slow, steady growth. Many beautiful wood-frame homes were constructed, with over 100 of these extant and cataloged with the National Register of Historic Places (Texas Historic Site Atlas 2000). The 1850 Census Products of Industry for Bastrop County lists 10 establishments, and included a saddletree maker, a wagon maker, three blacksmiths, and five saw mills. These industries reported an annual production of over $\$ 82,000$ in goods (Table 1). In 1852, the Ladies Reading Circle of Bastrop established one of the first libraries in the state, which remained in service until the Bastrop Public Library was organized in 1900. Bastrop Academy, a private school, was opened in 1851 and chartered in 1853. Among those that attended the school was a child of Sam Houston and a future Texas governor, Joseph Sayers. In 1872, the property of the academy became part of the Bastrop school system. The Bastrop Advertiser was established in 1853 and is recognized as the oldest, continuously published weekly newspaper in the state.
The county continued to grow throughout the $1850 \mathrm{~s}$, with new settlers arriving from the southern states and Germany. The 1860 Census Products of Industry for the county lists 14 establishments. These include a liniment manufacturer, a wagon maker, a blacksmith, a tin ware manufacturer, a grist mill, and nine saw mills. These industries produced over $\$ 156,000$ in goods that year (Table 2).

In early 1861,53 percent of the county voted against secession from the Union. But the county was drawn into the conflict anyway, since the majority of the state voted in favor of secession. The Civil War years (1861-1865) were especially harsh for the dependents of soldiers, but owing to the industry and resilience of its people, the town rebounded without much difficulty. The last three decades of the nineteenth century were especially generous to the area. This period ushered in the construction of a long-spanning iron bridge, railways, new towns, additional schools, brick-constructed public and private buildings, including a county courthouse and jail, and coal, iron, and cotton establishments.

The available census data serves to illustrate the tremendous strides made over the course of the nineteenth century. In 1835 Colonel Juan N. Almonte, acting on behalf of the Mexican government, reported that the Bastrop area population numbered approximately 1,100 . Within 15 years, the population increased by 182 percent. The population in 1850 numbered 3,099 (including 919 slaves) and the total number of farms was 219 . As noted above, the county census data for 1850 indicates that there were 10 manufacturing establishments, with an annual production valued at $\$ 82,000$. By 1900 , the county's population numbered 26,845 and there were 3,509 farms. Also by 1900, there were 87 manufacturing establishments in Bastrop County, with products valued at over $\$ 349,000$ (U.S. Historical Census Data Browser 2000).

\section{Local Industries}

Lumber was the first natural resource utilized in Bastrop County. Bastrop is the site of what is known as the "Lost Pines of Texas." This is an isolated pocket of Southern pine trees, in a 70 square mile area, which is located 80 miles west of the main pine belt. As early as 1840, A. W. Tunnard of Bastrop was advertising milled lumber in the Austin City Gazette. By 1850, the lumber mills in Bastrop County were producing over four million board feet of lumber, and close to two million planks of shingle 


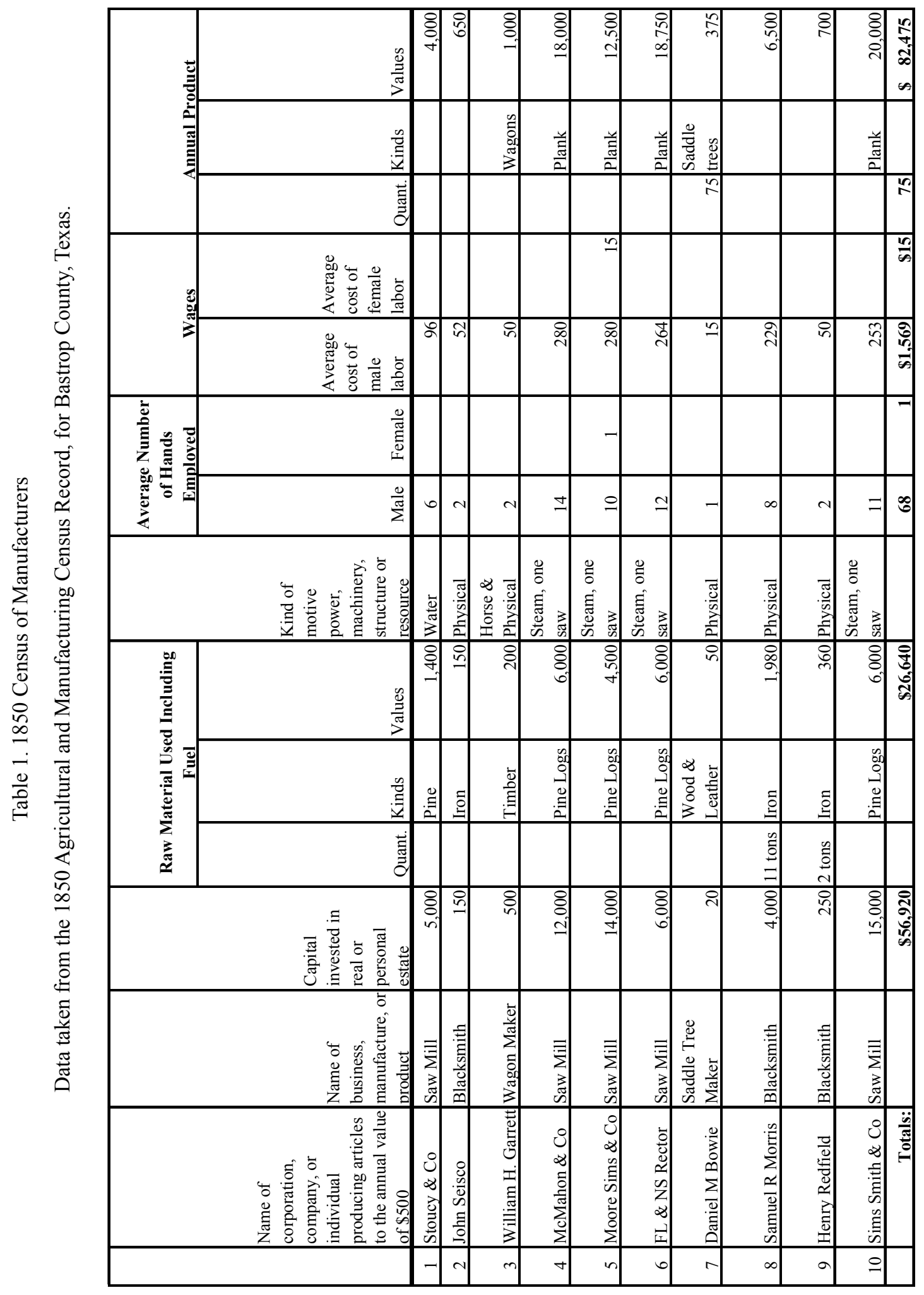




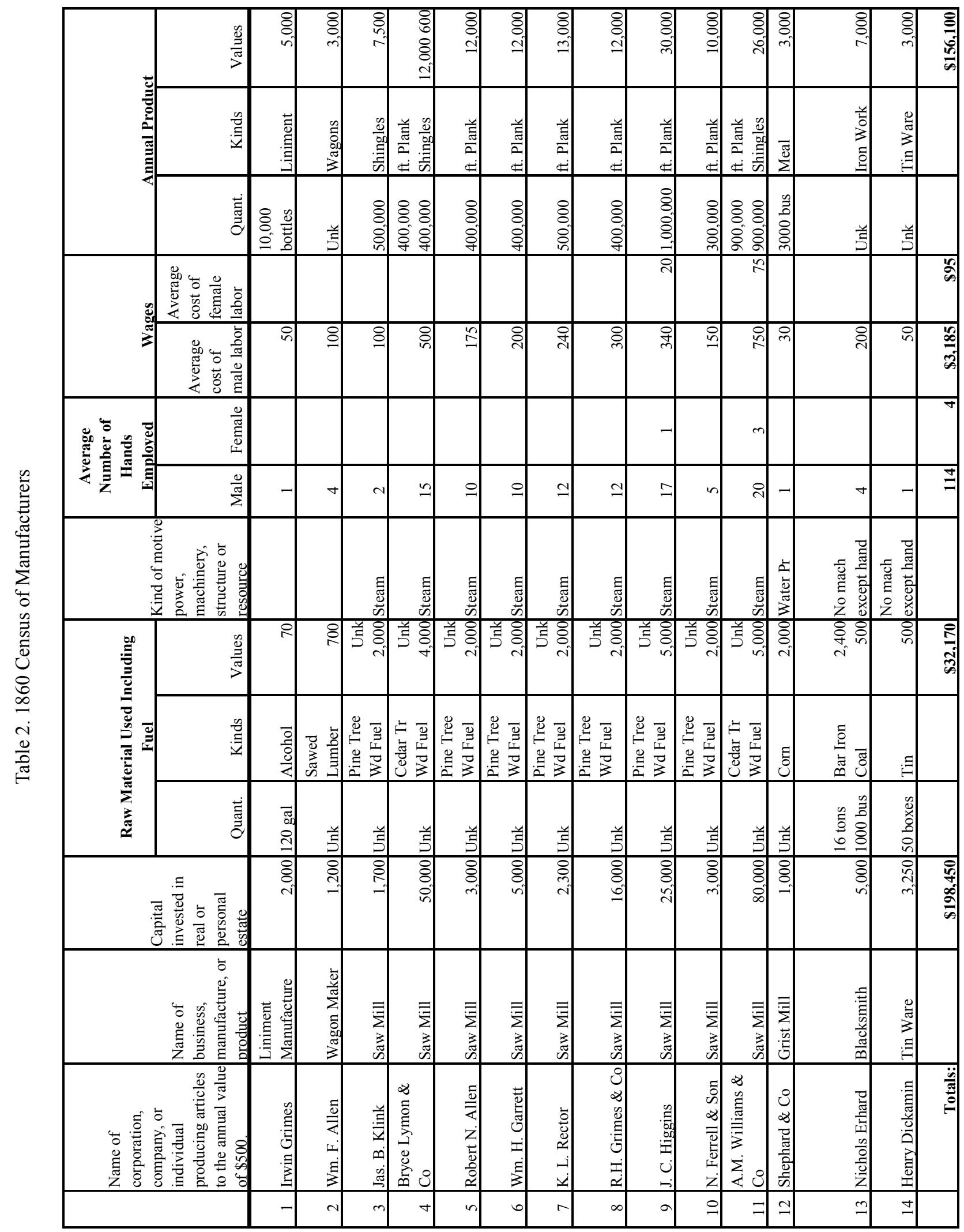


The T. C. Osborn Tenant Farm, 4IBP314

(Table 2). Local clay deposits were also utilized. In 1854 , a McDade Scottish potter established the Randolph Factory and manufactured a variety of pottery and jugs. By the 1870s, the manufacture of brick and tile became very important to the town of Elgin. Coal mining was also important to early Bastrop - the Bastrop Coal Company was organized in 1871. The first mine was the Goodman Mine near Bastrop, which was followed by the Mowatt coal mine, located about 2.5 miles from McDade and a short onehalf mile from the railroad tracks.

The cultivation and processing of cotton was another important local industry. The county boasted numerous cotton gins and mills, as well as cotton-producing farms. By the turn-of-the-century, the county was primarily agricultural, with a peak number of farms $(n=3,509)$ and peak production of bales of cotton $(n=41,730)$ reported in 1900 (Moore 1977:175-181). Unfortunately, between 1900 and 1950, the number of farms in Bastrop County decreased by 47 percent $(\mathrm{n}=1,858$ in 1950). The county's population also peaked in 1900 and actually decreased by 27 percent over the next 50 years (Table 3). A comparison between 1940 and 1950 indicates a pattern of growth and prosperity generated by World War II. The last column of Table 3 shows the 2000 Census data, which serves to illustrate the county's recovery over the past 50 years. Note that the county's population increased by 171 percent and the town by 103 percent.

\section{Transportation}

The most important factor behind the successful growth and development of a community is a safe and reliable means of transportation. Throughout most of the nineteenth century, travel through Bastrop County was accomplished by means of long established roads and ferries. People and goods were transported by way of the Old San Antonio Road and the Gotier Trace. The Old San Antonio Road, established ca. 1795, approached the Town of Bastrop from the northwest and then meandered through Bastrop along Chestnut Street. The Gotier Trace was a stretch of road that dated back to 1830 and ran from San Felipe de Austin to Mina (Bastrop). The town of San Felipe de Austin was located on the west bank of the Brazos River at the Old San Antonio Road crossing; off of present-day IH10 two miles east of Sealy in southeastern Austin County. As noted above, by as early as 1805 , the Spanish government had considered the Old San Antonio Road logistically important, to the extent that a small detachment of soldiers was posted at the Colorado River crossing, just above Gills Branch Creek.

Navigation along the Colorado River was intermittent and not very successful, with most attempts at steamboating occurring between 1848 and 1854. River crossings were accomplished up and down the Colorado by means of ferries. Such a ferry was used in Bastrop up until 1891 when a

Table 3. Population Data, 1850-1950

\begin{tabular}{|c|c|c|c|c|c|c|c|c|c|c|c|c|}
\hline Census Year & 1850 & 1860 & 1870 & 1880 & 1890 & 1900 & 1910 & 1920 & 1930 & 1940 & 1950 & 2000 \\
\hline County & & & & & & & & & & & & \\
\hline Population & 3,099 & 7,006 & 12,290 & 17,215 & 20,736 & 26,845 & 25,344 & 26,649 & 23,888 & 21,610 & 19,622 & 53,191 \\
\hline $\begin{array}{l}\text { \% Increase or } \\
\text { Decrease from } \\
\text { previous Census }\end{array}$ & & $126.1 \%$ & $75.4 \%$ & $40.1 \%$ & $20.5 \%$ & $29.5 \%$ & $-5.6 \%$ & $5.1 \%$ & $-10.4 \%$ & $-9.5 \%$ & $-9.2 \%$ & $171.1 \%$ \\
\hline $\begin{array}{l}\text { Town/City } \\
\text { Population }\end{array}$ & & 1,088 & & & & & & & 1,895 & 1,976 & 3,176 & 6,456 \\
\hline $\begin{array}{l}\text { \% of County * } \\
\text { (Population) }\end{array}$ & $\cdots$ & 15.5 & & & & & & & 7.9 & 9.1 & 16.2 & 12.1 \\
\hline
\end{tabular}

* The 1850 population total includes 919 slaves ( $29.5 \%$ of county population); unable to determine how many were in the town of Bastrop. The 1860 census includes 2,591 slaves ( $37 \%$ of county population), of which 300 were in the town of Bastrop and included in the count. Shaded areas indicate data unavailable.

(Data retrieved from the Lower Colorado River Authority 2000; U.S. Historical Census Data Browser 2000) 
bridge was finally built. The 1,200-foot iron bridge was constructed across the Colorado at Chestnut Street in 1890, at a cost of $\$ 45,000$ (Moore 1977:94).

The Houston and Texas Central Railroad (later renamed the Southern Pacific) made its first run through Bastrop County in 1871. This was improved in late-1887, when the Missouri, Kansas, and Texas Railway (M.K.T.) made a connecting line through the town of Bastrop possible; the tracks in fact cut through the western half of the Osborn Farm. By early-1893, the M.K.T. had a connecting line to Houston. The railroads spurred and guaranteed the county's commercial growth during the late-1800s, as evidenced by the growth of towns such as Paige, McDade, Elgin, and Smithville (Moore 1977).

\section{Local Labor}

As we praise the resolve and skills of the early entrepreneur, we should also consider an important factor that contributed greatly to this early prosperity. Prior to the emancipation of Southern slaves in 1865, approximately one-third of the county's labor pool was comprised of slaves. In 1850 , the slave population was 29.5 percent of the county's total, and this increased to 37 percent in 1860 . The early history and development of the Osborn Farm is owed in large part to a number of slaves that worked the Castleman, and then Jones, farms between 1840 and 1865 (see Results section). Many of the emancipated workers continued to live in the area, and about 60 percent stayed on as agricultural workers, but eventually began to filter out into urban settings. As told by Irella Battle Walker, a former slave of Bastrop and Travis counties, there wasn't much else they could do but stay:

One mornin' Massa Washinton call us all and he read from de big paper. He say, "You is free to live and free to die and free to go to de devil, if you wants to." He tell us if we gather he crops he'd pay us for it. Den he turned and walked away and started cryin'. All de families stays but one man. De highest price massa pay anybody was about $\$ 15.00$, but dat seem like a lot of money to folks what wasn't used to gittin' any money at all (American Memory 2001).

By the late-1800s, and certainly during the early-1900s, the African American agricultural work force was beginning to be supplemented by an ever-increasing number of farmers and farm laborers of Mexican origin that begin to filter into the Cotton Belt region. Most accounts suggest that up until early-1900, the Mexican-origin population in central Texas was minimal. Based on the findings of this study (see $R e$ sults) we would have to agree with Montejano (1987:31) that the Mexican-origin population was seriously under counted. Nevertheless, owing to a variety of national and international forces - economic, political, and social - there was an influx of Mexican and Mexican American laborers into the Bastrop area during the early-1900s. This early1900 surge in immigration by Mexicans and Mexican Americans is of interest to this study. The conditions under which this population immigrated and by which they were employed are further examined below. 


\section{Previous Research}

No archaeological studies had been conducted on the T. C. Osborn site prior to 1987. David Robinson, of the Texas Archeological Research Laboratory (TARL), investigated the neighboring G. W. Jones site in 1989. As advanced in the Results section of this report, ownership and enterprise closely link the Jones and Osborn sites.

In 1989, the TARL investigators conducted a field survey and archival research of the G. W. Jones house and outbuildings. The field survey was intended to map and record all structures and features, especially if they were thought to be of historical and/or chronological significance. The archival research was conducted in an effort to provide a history of ownership and occupancy. An ancillary research issue was the verification of whether or not there was a prehistoric component on this site, as reported in a Texas Historical Commission architectural survey of 1977. The results of the field survey and archival research suggest that the single-pen log cabin behind the Jones house was constructed ca. 1840 during W. Pinkney Hill's ownership. Robinson suggests that Jones constructed the two-story house and double-pen log barn ca. 1856. Construction of the rest of the features is attributed to the Osborn ownership, or post1906. Robinson suggests that the Jones homestead consisted of approximately two acres, delineated by the house and barn on the south side and Mill Street on the north side. He further noted that T. C. Osborn constructed two board-andbatten sheds to the northeast of the Jones house and another two board-and-batten tenant houses "elsewhere on the property" (Robinson 1989:42). Finally, Robinson noted that the Osborn Farm was cultivated up until 1952, when the fields were leased for pasturage and all the houses abandoned and left to ruin. As for the supposed prehistoric site, this was determined to be unverifiable and thought to have been modern chipped stone or simply introduced as road construction material.

The Robinson study was useful in that we were able to corroborate and extend his conclusions. The site plan of the $\mathrm{G}$. W. Jones site was extremely helpful in the development of a plan that depicts the entire operation for the Osborn Farm. These additional findings and revised site plan are presented in the Results section.

The research methods described in the following section were designed to maximize the utilization and interpretation of the data relating to the use and history of the T. C. Osborn Farm site (41BP314). In an effort to present a concise narrative of the site and its occupants, several primary sources were pursued and, to the extent available, covered a 125-year period (1825-1950). Part of the data was recovered during the 1987 fieldwork, and the remainder was secured in late 2000. This later research included extensive archival research and the recovery of oral histories. The oral histories were especially complementary to this study, as they involved former tenants of the T. C. Osborn farm who related their pre-1950 life histories. 


\section{Scope and Methods}

\section{Archival Research}

Some of the details pertaining to Bastrop's early history were collected from the U.S. Census, Schedules of Population and Manufacturers, while additional data was secured from deeds, property plats, and similarly relevant records filed with the Bastrop County, County Clerk's Office (BCC), since 1837. This research also included a review of the listed historic properties of Bastrop, current property plats of the Bastrop Central Appraisal District, the local history files of the Bastrop Public Library (BPL), and consideration of the photo collection of the Institute of Texan Cultures, University of Texas at San Antonio.

The U.S. Census schedules were used to reconstruct the town's demography and examine the relative economic and social condition of each ethnic group. The Bastrop County census data from between 1850 and 1950 was reviewed, tabulated, and presented in a series of tables. This research provided us with the names and vital statistics for many of the key players, as well as information relating to the area's population, racial/ethnic affiliations, occupations, land/home ownership, and immigration patterns. Several microfilm reels were reviewed, many of which were found to be in very bad condition and barely legible. With the exception of 1890 , which is no longer available, this information was secured from the Schedule 1, Population from between 1850 and 1900. The Schedule 2, Slave Population for 1850 and 1860 reels were reviewed and were in especially bad condition. These schedules were limited in use, since only the name of the slave owner is listed. The slaves are merely listed by sex, age, and color. The Schedule 5, Census of Manufacturers, for Bastrop County for 1850 and 1860, were also used. These were especially helpful in providing a glimpse of the various industries and products. Another resource, which was much less taxing and extremely useful, was the University of Virginia's "Geospatial and Statistical Data Center" (U.S. Historical Census Data Browser). This web site was used extensively in order to conduct comparative research at the state and county levels. This data center is an excellent interactive research tool that can be used to broadly depict populations and economies from between 1790 and 1960.

Another part of the archival research involved sampling the birth and death records for Bastrop County. These data were used in an attempt to gauge the racial and ethnic demographics for Bastrop County. With regards to birth records, the county's oldest birth register (BCC, vol. A\& 1) was sampled in an effort to determine the earliest occurrence of Mexican families. With regards to the county's death records, we were fortunate in having access to several binders that alphabetically indexed the county's burials. The Bastrop County Historical Commission in the mid-1980s compiled these indexes, titled Lists of Cemeteries. These indexes were accomplished through the work of several historical commission members who visited 106 public and private cemeteries, and inventoried 10,010 named graves (BCC, Cemetery Indexes 1987).

Some of the work that related to abstracting the T. C. Osborn property was initiated in 1987 . These initial leads were pursued and ultimately proved useful in documenting land ownership from the earliest conveyance, to the T. C. Osborn ownership, as well as to its current disposition. Land grants, deeds, wills, and probates, as well as related maps and plats, were used to present a history of land ownership and site development. This process required a deliberated examination of the index to deeds, direct and indirect, in order to cross-reference and then locate the relevant record. These same records were very useful in establishing the site's boundaries and its relationship to the nearby G. W. Jones Site (41BP86 [Robinson 1989]).

This research focused on late-1800 and early-1900 site improvements (i.e., structures and outbuildings). Towards this end, the earliest recorded (ca. mid-1800) Mechanics Liens were reviewed, without success. Although numerous building contracts were recorded during the period of interest, none were located that related directly to the Osborn Farm.

A search for photos relating to the site and community in general was also undertaken. It was hoped that we would be able to locate early-twentieth century visual depictions of the site, but this proved unsuccessful. We had also hoped to find and include personal family photos in this report, but none of the persons that grew up on the Osborn Farm had any early photos. The earliest photos of the Osborn Farm are from ca. 1936, but were limited to the main house and out-buildings that were associated with the $\mathrm{G} . \mathrm{W}$. Jones house (Robinson 1989:10-13).

The use of aerial photos and property plats proved very productive, in terms of producing a fairly accurate layout of the farm. A total of five distinct maps were used to come up with a ca. 1920 plan view of the property that shows the houses and outbuildings. The maps used included a 1920 
map of the Town of Bastrop (Iredell 1920), a ca. 1929 property map for Bastrop County (Randolph Blueprint Company 1929), a 1982 United States Geological Survey quadrangle map of Bastrop County (USGS 3097-121), a 1998 USGS aerial map (MSN TerraServer ${ }^{\circ}$ 2000), and a 1998 Bastrop Central Appraisal District property map (BCAD AP 10-11).

\section{Oral Histories}

To a great extent, the archival records and artifactual data were enhanced through a series of oral histories. Former tenants of the Osborn Farm were located by following-up on names mentioned in Robinson's (1989) report, as well as those in John Clark's field notes. With the assistance of members of the Bastrop community, we were able to locate these former tenants and record firsthand details relating to the occupancy and site use of the Osborn Farm.

The project assessment completed by the Texas Archeological Research Laboratory (TARL) (Ross 1993) strongly recommended that Rudy Martínez, the son of Mr. Pete Martínez, original tenant farmer, and retired tax assessor Mr. Clyde Reynolds be interviewed. Through the assistance of Esther Coy, we were able to locate and interview 95year-old Mr. José Barrón. Mr. Barrón in turn introduced us to his son-in-law, Pete Martínez, Jr., oldest brother of the above noted Rudy Martínez. The Martínez brothers then pieced together a site history, and in the process made mention of other former tenants. This bit of knowledge then led to the location and interview of 93-year-old Mrs. Louise García and her daughter, Emma Rockwell, nee García. Unfortunately, we were unable to follow through with the second person TARL suggested be interviewed, since Mr. Clyde Reynolds passed away in March 2000.

An interview protocol was developed prior to initiating any of the above-mentioned interviews. This protocol comprised a series of questions relating to family history, social relations, house occupancy, and site utilization. The first series of questions attempted to obtain information pertaining to why and when their family settled in Bastrop. We also attempted to determine the process of immigration into the Bastrop area, and inquired as to whom in their family was the first to arrive and why they chose Bastrop, for instance, was there someone or something pulling him/her towards this area? Site-specific questions were also pursued, such as the type of work arrangement, or contract, his/her family had with T. C. Osborn, location of outbuildings and work areas, as well as relations with other farmers, the Bastrop community, and other Mexican families. In one case, Pete Martínez, Jr. and the interviewer drove through the site and reminisced about the Osborn Farm, its service roads, outbuildings, main house, barn, and corral. This was an especially useful exercise, since placing Mr. Martínez back in the setting helped to bring forth memories that had been set aside for some time. Mr. Martínez recounted long-lost particulars about the farm and its operations, and pointed out where different features had once been. These interviews were then summarized and copies, with follow-up questions, were routed to the participants for consideration. We were quite fortunate in that all of the summaries were returned, and additional information obtained. Through this process, we believe, we were successful in rescuing a wealth of family and community histories.

\section{Artifacts and the Built Environment}

The original field sketch of the T. C. Osborn tenant farm site shows a relatively small study area of approximately $120 \mathrm{ft}$. by $180 \mathrm{ft}$. on which the house and well were located. Based on the field notes compiled by John Clark in 1987, the T. C. Osborn site was initially occupied ca. 1906. An analysis of all diagnostic artifacts collected in 1987 was then completed in order to determine the site's temporal limits. Over 9,000 artifacts were recovered in 1987, and these included an assortment of glass and ceramic sherds, personal items, hardware, and numerous other constructionrelated material. The most predominant artifact on hand were the remnants of what once had been a four-room boardand-batten house.

This research included the standard descriptive and chronological treatment of the artifactual and architectural data. The faunal material, presented separately, was analyzed and is discussed with regard to the predominance of one meat source over another and types of cuts of meat. The house remnants and associated outbuildings were also considered in this study. As noted earlier, our attempts to reconstruct the site based on old photos proved futile. We then resorted to relying on the archaeologist's field descriptions, workin-progress photos, and field sketches. This collection of data was then used to produce a series of conjectural drawings (plans and elevations) that were verified by one of the former tenants, Emma Rockwell. This same information was used to produce a site plan of the house and its relationship to other features and outbuildings. 
Based on the limited amount of information gathered in 1987, we had assumed that the tenant families migrated north towards the Cotton Belt region in the early 1900s, and that for some reason yet to be determined, they decided to settle in Bastrop on the T. C. Osborn property. As stated previously, our investigation was directed towards responding to two basic issues: 1) Mexican immigration patterns, and 2) social and economic relationships within an early twentieth-century rural community. The following is our interpretation and synthesis of the archival records, oral histories, and artifact analyses, which respond to when and why the tenant families emigrated from Mexico, and why and under what conditions they chose to settle in Bastrop. 


\section{Results}

The T. C. Osborn tenant house site was investigated in February and March 1987 by John Clark of the Texas Department of Transportation (TxDOT), prior to being impacted by a proposed road improvement. A total of 32 units were excavated and two areas bladed, which resulted in the recovery of numerous artifacts, including ceramic sherds, glass fragments, beads, marbles, cut and wire nails, assorted metal objects, buttons, and bone fragments. This site also underwent HABS, Level 3 documentation, so that a series of measured drawings of the demolished four-room board-andbatten home were realized and are presented in the following section. The fieldwork was complemented by means of archival research and a series of oral histories, carried out during the latter part of 2000. The following section reports the results of the fieldwork and of the ancillary research.

\section{Fieldwork}

Investigations at the Osborn site focused on an area approximately $80 \mathrm{ft}$. wide, from east to west, by $160 \mathrm{ft}$. long, from north to south. This 12,800 square foot area is shown in Figure 5. Thirty-two units were excavated within the immediate vicinity of the structure, as well as to the north and south. Thirteen units were excavated within the house and in the immediate vicinity, while an additional six units were located and excavated to the south and southeast. Another thirteen units were located and excavated to the rear, or north, of the house. Two areas, to the north and northeast of the structure, were investigated with the use of a gradall. These areas were graded in an effort to locate related site features, such as a privy or other outbuilding.

With the exception of one triangular-shaped unit (N510/ E505), all other units were $5 \mathrm{ft}$. by $5 \mathrm{ft}$. $(1.5 \mathrm{~m} \mathrm{x} 1.5 \mathrm{~m})$ and excavated in a single level to about 12 inches $(30.5 \mathrm{~cm})$ below surface. Excavated soils were screened on 1/4-inch hardware cloth and artifacts were bagged in individual lots (artifact bags). The work was completed over a 10-day period between February 17, 1987 and March 6, 1987. A grid was set up using station marker $13+00$ as the base line, with the grids at $20 \mathrm{ft} .(6 \mathrm{~m})$ intervals. The horizontal datum was set at N500/E500. The north-south line of the grid followed the centerline of the road, rather than in an exact straight line, so that the line curved eastward. The east-west lines were perpendicular to the tangent of the curve (Figure 5).

What was left of the tenant house (Figure 6) was described as being $281 / 2 \mathrm{ft}$. in length (east-west), $141 / 2 \mathrm{ft}$. deep (northsouth) and with a lean-to addition at the rear that was $7 \mathrm{ft}$. deep and ran the length of the house. The house was constructed on a pier and beam foundation. These piers were 6 in. diameter cedar posts; the dimension of the sills was $4 x$ 6 in., and the floor joists were $2 \times 6$ in. There was no indication of whether any of the lumber, especially the framing material, was full- or nominal-dimension, which would have provided a bit more information concerning the structure's date of construction. An east-west dirt road was located in front of the house, and is seen in the foreground of Figure 6. This same figure illustrates the condition of the house and site in late-February 1987. A barbed wire fence ran north to south along the west side of the house, between 10 and 12 $\mathrm{ft}$. away from the structure's west elevation.

The soils in this area consisted of fine sandy loam, classified as a Smithville series ( $\mathrm{Sm})$. This soil is excellent for crops and pasture and typically supports a scatter of pecan trees that are used for shade and production of nuts. The typical stratigraphy consisted of a grayish-brown fine sandy loam from $0-6$ in. below surface (10YR5/2), a dark grayish-brown loam from 6-16 in. below surface (10YR4/2), a reddishbrown sandy clay loam from 16-30 in. below surface (5YR4/ 3 ), a reddish-brown sandy clay loam from 30-50 in. below surface (5YR5/4), and a reddish-yellow fine sandy loam from 50-62 in. below surface (5YR6/6) (Baker 1979).

The first unit excavated was TU-1, located along the west side of the house, immediately south of the chimney. This unit was situated along the chimney base, and extended to the southwest corner of the house. Concentrations of brick occurred along the northwest one-fourth and the southeast corner of the test unit. The base of the chimney was constructed of four courses of brick below grade. Based on the size of the brick ( $2 \frac{1}{4} \times 4 \times 81 / 4$ in.), the base must have been a mere 9 to 10 inches below grade.

While some of the crew continued excavating in the area of the house, other members moved over to an area about 80 $\mathrm{ft}$. north, to the rear of the house. The area was cleared of heavy brush and then bladed with a gradall in an effort to locate the privy. In addition to blading the area, a series of five units were located in an area between 80 and $110 \mathrm{ft}$. north of the house in a continued search for the privy. A pile of fence material was cleared away in an effort to locate the privy and/or other related features. The search efforts included the use of a soil auger to a depth of about $3 \mathrm{ft}$., at 5 $\mathrm{ft}$. intervals. These probes were executed along line E480 from N540 to N610, along line E475 from N540 to N570, and along E470 from N545 to N560. The auger was also 
The T. C. Osborn Tenant Farm, 4IBP314

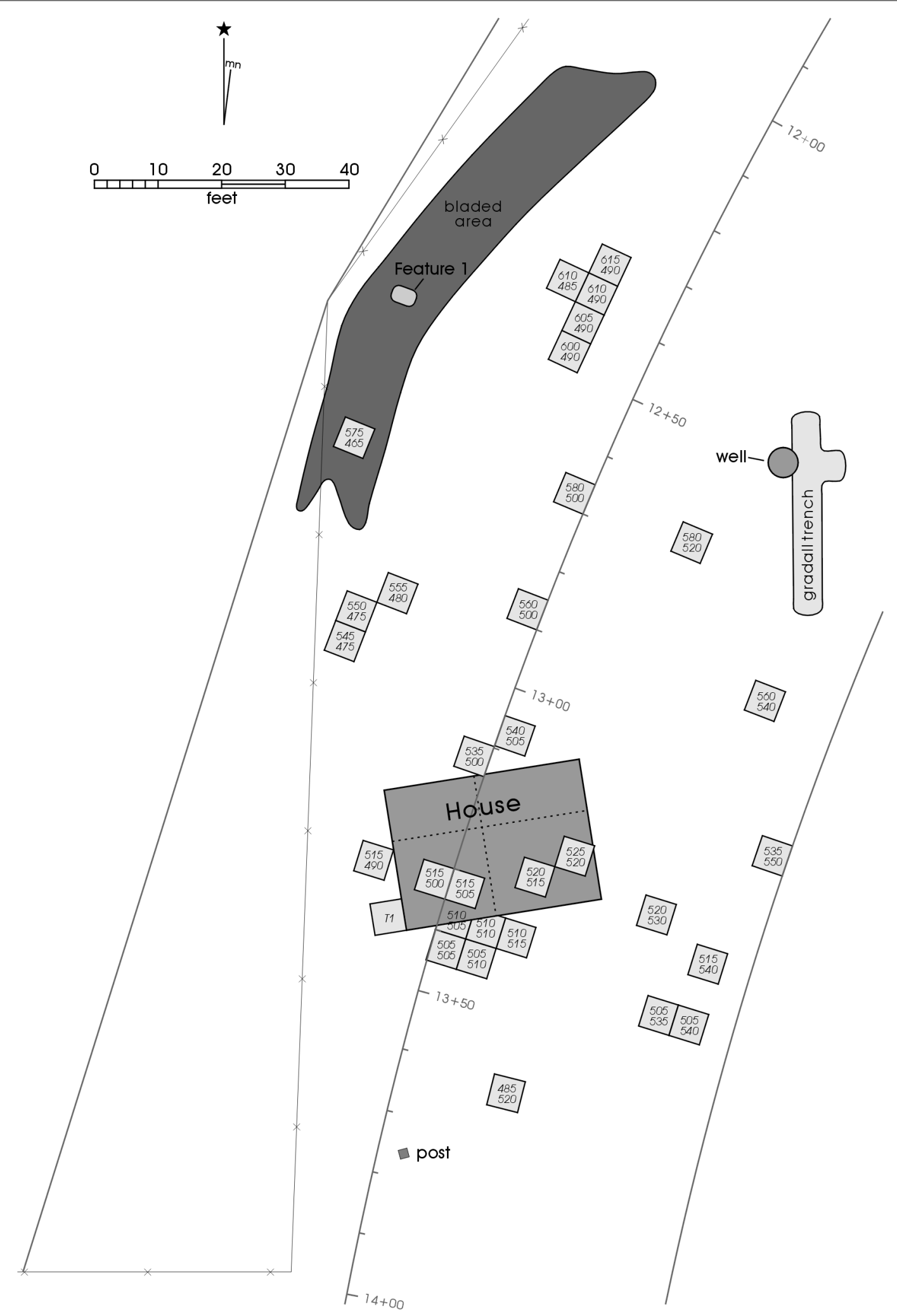

Figure 5. Project area showing features, units, and bladed areas. 
The T. C. Osborn Tenant Farm, 4IBP314

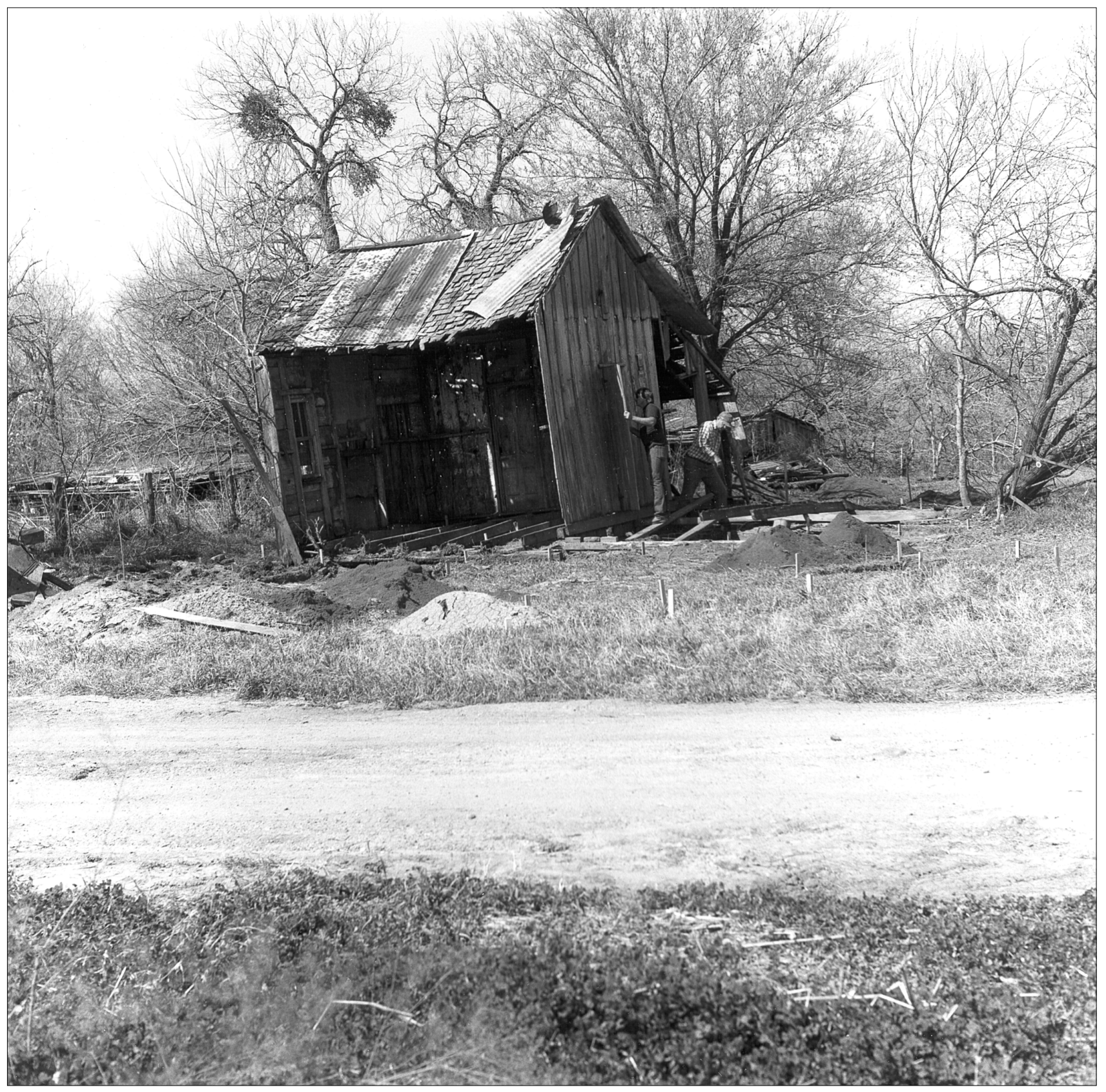

Figure 6. Photo of the Osborn tenant house taken February 1987. 
used at the following coordinates (approximately): N548/ E470, N548/E475, N548/E473, and N545/E475.

After much effort, the crew located what appeared to be a privy outline and designated this Feature 1 . This feature was oblong and measured approximately $3 \mathrm{ft}$. by $4 \mathrm{ft}$., and appeared as a light brown silty loam with lots of gravel. The surrounding soil was the usual dark brown loam, and was much more clayey. The lighter area was roughly rectangular in outline. A wooden post and associated post-hole stain were visible in the northeast corner of the feature. The posthole stain was about $8 \mathrm{in}$. in diameter. The post was rectangular in cross-section and must have been a 2-x-2 in. post. The feature was mapped and photographed prior to being excavated. The pit was filled with gravel and extended to no more than $40 \mathrm{in}$. below grade, with the top 20-25 in. having been removed by the gradall. The post extended from the top of the scraped surface down to only about 5 in., suggesting that it had originally been buried some $2 \mathrm{ft}$. below grade. No evidence of a privy was found and it was then interpreted as a gravel-filled pit of undetermined use or age.

The probes resulted in a similar profile as that described for the trench profile. The orange (reddish-brown) silty soil appeared gradually at between 26 and $30 \mathrm{in}$. below the surface. At three test locations, the transition from dark clayey loam to the orange siltier soil was abrupt rather than gradual. These probes were located at N548/E475, N548/E473, and at $\mathrm{N} 545 / \mathrm{E} 475$. This area also had very dark soil and the nearby 5 x $5 \mathrm{ft}$. test units (N550/E475 and N555/E480) seemed to have had a relatively higher concentration of artifacts. The anomaly may indicate the presence of a trash pile or shallow pit. The depth of the abrupt transition occurs at about 30 inches below surface. Although the probes were undertaken in order to locate the privy, no evidence of a deep pit, lime deposits, or other indications of a privy were found.

Unit N505/E505 was located in front of the house and oriented with the main grid for the site. The soil in this unit was dark and loamy; two cobbles and one brick fragment were recovered. A triangular-shaped unit, N510/E505, was located adjacent to and north of Unit N505/E505. The recovered cultural material was more varied at this location and included such items as a 1919-penny and a mentholatum bottle. A trapezoidal-shaped test unit, N510/E510, was located north of and adjacent to N505/E510. The north edge of this test unit was located along the southern edge of, and in front of, the house. This unit further exposed the chimney base and pier and beam foundation, which were then photo documented. A series of seven units were excavated within $30 \mathrm{ft}$. to the north, rear, of the house with little results. Another series of units were excavated inside the house, beneath the flooring, with little or no results.

A brick-lined well, located approximately $60 \mathrm{ft}$. northeast of the house was also excavated. The rim of the well had been buried about $2 \mathrm{ft}$. below grade, and was $3 \mathrm{ft}$., 4 in. in diameter (outside dimension). After clearing the area of brush, a gradall was brought in and the well cross-sectioned. The water in the well was pumped out and then one side was dismantled. The west profile of the trench adjacent to the well was cleaned off in order to observe and document the stratigraphy at the site. The uppermost layer consisted of a dark brown clay loam from 0-26 in. below surface. An orange silty loam or silty clay loam with caliche and mottling, due to insect burrowing, extended from 26 in. to over 60 in. below the surface. The transition between the two zones is gradual in the trench profile. The soil is a fairly typical alluvial silty clay loam overlain by a mollic A horizon typical of prairie soils. The final depth of the well was estimated to be at least $28 \mathrm{ft}$. below surface. Given that the depth of the well was well beyond the limits of the rope ladder and pump capabilities, further investigation was ceased.

Unit N580/E520 was located about $20 \mathrm{ft}$. south of the well and the soil was a typical dark brown loam, but somewhat gravely with small roots. The unit was excavated to 6 in. below surface and since there were no features present, only the west half was excavated to a final depth of $12 \mathrm{in}$. below surface. Very few artifacts were recovered, so that the unit was then photo documented and backfilled.

In sum, only one definitive feature was identified: a bricklined well was located at the rear of the house, about $60 \mathrm{ft}$. to the northeast. A section of the well was dismantled and further excavated with a gradall in an effort to reach its final depth. This was not possible as the well proved to be at least $28 \mathrm{ft}$. deep and still drawing in water. A depression was excavated, as it had been thought to be the location of a privy, but found to be too shallow to have served this purpose. Close to 45 percent of the lots had artifact counts of between 100 and 400, and only two lots had in excess of 1,000 artifacts. Upon closer examination, it was noted that these last two lots were collected from units located at the rear of the house (N545/E475 and N580/E500). There were 
an additional three units within the general area of N545/ E475 and N580/E500. One of the units also had a relatively high count of 622 artifacts, while the other two had average counts of close to 300 per lot. Between 15.5 and 16 percent of the artifacts of both units were ceramic fragments, and between 27 and 29 percent of the artifacts consisted of glass shards.

\section{Ancillary Research}

The following summarizes the results of an exhaustive review of the literature, archival research, and oral histories. These diverse sets of primary and secondary sources were undertaken in an effort to present a synthesis of cotton farming, Mexican immigration, sharecropping, and biographical sketches. Since the principal source of income for these tenant farmers was cotton, we will first present an overview of cotton farming in Bastrop County. This section is followed by four additional sections: a site description that locates the homes and outbuildings, a site history that details the ownership of the farm, an account of the tenant families that worked the farm, and personal narratives about sharecropping.

\section{Cotton Farming}

An overview of Bastrop's early industries was previously provided in the Historical Background section. This background information suggests that the county enjoyed a certain amount of success as a result of its industries. This is all true, but we should also understand that the county's industries required a considerable amount of labor, and that by 1840 , the work fell on an ever-increasing number of slaves.

Slave labor was a key issue throughout the Texas colonization period (1821-1830). Despite the contributions made by numerous African Americans to the Texas fight for independence, their status did not improve. If anything, their condition worsened. The newly formed Republic of Texas wasted no time in limiting the additional immigration of "free men" (emancipated African Americans) into Texas, as well as restraining the legal status of those already residing in Texas. The Mexican government was never amicable to the institution of slavery, and by 1823 instituted a law that prohibited the purchase or sale of slaves. This same law required that children of slaves be emancipated at the age of 14. In 1829 and 1830, the Mexican government imposed further restrictions on slavery that, by intent, also curtailed the number of new immigrants from the southern
U.S. These restrictions were considered significant grievances for many Texans who eventually rebelled against Mexico (Barr 1973).

The noted lumber and cotton industries, which took off between 1840 and 1850, relied heavily on slave labor. With the annexation of Texas by the U.S. in 1845 , slavery in the state was allowed to continue on through the end of the Civil War. The industries, which had profited through the use of slaves, suffered considerably as a result of the emancipation of over 250,000 African Americans in Texas (Juneteenth-June 19, 1865). Emancipation also brought on changes in the area's political and social life, which caused a number of serious racial confrontations, most notably around the community of Cedar Creek, about 12 miles east of Bastrop (Handbook of Texas Online 2000).

After emancipation, some African Americans left the rural communities for jobs in the cities, but most remained in agricultural settings as sharecroppers or tenant farmers. Agricultural workers typically worked 55-hours per week, and in return were paid between $\$ 2.00$ and $\$ 5.00$ per week. These workers received fuel and food rations and a minimal amount of medical care. African American tenant farmers almost never profited, because close to 60 percent of them farmed small plots of less than 50 acres. In addition, the landowners and storekeepers allowed them to purchase food and supplies on credit, but at interest rates as high as 25 percent. In this way, even after emancipation, the "freedmen" were forced to continue working on plantations under less than favorable conditions (Barr 1973).

By 1900, 63 percent of the employed African American population of Texas was involved in some form of agriculture. Thirty-one percent of the African American farmers of Texas were landowners, and 69 percent were sharecroppers. In comparison, Bastrop County reported 3,509 farms in 1900 , and of these, only 1,339 (38 percent) were operated by "colored" farmers. Of these 1,339 farms, 313 (9 percent of the total) were actually owned by "colored" farmers. These numbers and percentages remained constant in Bastrop County up until 1940, when they began to decrease by as much as 10 percent.

Between 1940 and 1970 the black rural population in Texas declined steadily as more people moved to urban areas. Also, between 1940 and 1960, the number of black tenant farmers and sharecroppers declined from 32,610 to 3,138 (Barr 1973; U.S. Historical Census Data Browser 2000). 
Table 4 illustrates the increase, and subsequent decrease, in farms at the state and county levels. In Bastrop County, the total number of farms peaked in 1900 , whereas this did not occur statewide until 1930. It is interesting to note the incredible surge in the number of farms in the state and county in 1860 , and then again in 1880 .

Since the turn-of-the-century, a reserve of low-paid Mexican labor has existed just across the border and was an important factor in the development of large-scale agriculture in south and central Texas. Mexicans came by the thousands in the years following World War I to work on farms at wages of about $\$ 1.00$ per day. In most cases, the economic advantages afforded by employment in the U.S. pulled Mexicans to Texas, just as violence and social and economic disorganization occasioned by the Revolution pushed them out of Mexico (Hall and Coerver 1988). The average income of U.S. workers in 1900 was low, between four and five hundred dollars a year at a time when six hundred dollars was considered the minimum for bare comfort. The average work schedule was ten hours a day, six days a week (Gómez-Quiñones 1994).

In an effort to locate some evidence as to the longevity of Mexican families in Bastrop County, a review of the county birth and death records was undertaken. A random sample of the index to death records for Bastrop County located two Spanish-surnamed deaths in 1904 and one in 1907 (BCC, Index Book 1). These two entries could be considered among the earliest recorded. A review of the county's oldest birth records located three children born of Mexican parentage: Vanetta Cardenas, born September 4, 1874 (entry no. 99), Callistro Alanisi, born October 14, 1874 (entry no. 101), and María Falconia, born August 8, 1874 (entry no. 103) (BCC, vol. A \& 1). We note here that the first part of the book contains Volume A entries, from ca. 1861 to 1902 , and the second part contains Volume 1 entries, from ca. 1903 to 1912. A total of 248 births were recorded in Volume A; of these, 13 (5 percent) were of Mexican parentage and 24 (9 percent) were of "Colored" or "Negro" parentage. This data, however, should be weighed with some caution, since it is a well-known fact that many rural families were remiss in registering births and deaths. It would be incorrect to use the data to estimate the county's demographic composition. We can, however, use this information to propose that there was indeed a Mexican presence in the county well before the 1900 s.

There were 226,000 Mexicans in Texas in 1910, and by 1930 the number had increased to 683,000 (Menefee 1941). According to a Bureau of Labor Report published in 1908, the transition in Texas from temporary immigrants to settlers was quite noticeable. Among the first to recognize this trend was a railroad official. This official noted that, initially, the vast majority of immigrant laborers were males traveling back and forth without their families (Clark 1999). Over a ten year period (1898-1908), however, there was a marked increase in the number of men who brought their wives and children, and men who returned for their families (Clark 1999:205). The Mexican population of south Texas was concentrated along the Texas-Mexico border from Cameron County, at the mouth of the Rio Grande, to Val Verde County; and in the southwest sector of the cotton belt region, extending from east Texas to the area south of Austin and San Antonio, and down towards Nueces County (Zamora 1993). This area included Bastrop County.

Table 4. Farm Data, 1850-1950

\begin{tabular}{|l|c|c|c|c|c|c|c|c|c|c|c|}
\hline & $\mathbf{1 8 5 0}$ & $\mathbf{1 8 6 0}$ & $\mathbf{1 8 7 0}$ & $\mathbf{1 8 8 0}$ & $\mathbf{1 8 9 0}$ & $\mathbf{1 9 0 0}$ & $\mathbf{1 9 1 0}$ & $\mathbf{1 9 2 0}$ & $\mathbf{1 9 3 0}$ & $\mathbf{1 9 4 0}$ & $\mathbf{1 9 5 0}$ \\
\hline $\begin{array}{l}\text { Total Farms } \\
\text { STATE }\end{array}$ & 12,198 & 37,363 & 61,125 & 174,184 & 228,126 & 352,190 & 417,770 & 436,033 & 495,489 & 418,002 & 332,837 \\
\hline $\begin{array}{l}\text { Farms- } \\
\% \text { Incr/Decr }\end{array}$ & $\mathrm{n} / \mathrm{a}$ & $206.3 \%$ & $63.6 \%$ & $185.0 \%$ & $31.0 \%$ & $54.4 \%$ & $18.6 \%$ & $4.4 \%$ & $13.6 \%$ & $-15.6 \%$ & $-20.4 \%$ \\
\hline $\begin{array}{l}\text { Total Farms } \\
\text { COUNTY }\end{array}$ & 219 & 596 & 719 & 2,231 & 2,069 & 3,509 & 3,096 & 3,325 & 3,207 & 2,473 & 1,858 \\
\hline $\begin{array}{l}\text { Farms- } \\
\% \text { Incr/Decr }\end{array}$ & $\mathrm{n} / \mathrm{a}$ & $172.1 \%$ & $20.6 \%$ & $210.3 \%$ & $-7.3 \%$ & $69.6 \%$ & $-11.8 \%$ & $7.4 \%$ & $-3.5 \%$ & $-22.9 \%$ & $-24.9 \%$ \\
\hline
\end{tabular}

Data retrieved from the University of Virginia, U.S. Historical Census Data Browser 2000. 
In January 26, 1920, Fred Roberts, cotton farmer and president of the South Texas Cotton Growers Association, Corpus Christi, Texas, spoke before the U.S. House of Representatives (USHR), Committee on Immigration and Naturalization, in favor of admitting Mexican farm workers. When pressed by one of the committee members about the possibility that most Mexican workers might remain in the States, Mr. Roberts responded that to the best of his knowledge 98 percent of the workers returned home (USHR 1920:53). Mr. Roberts went on to comment that, "Sometimes one will stay when a man wants a good laborer, or you will find one that is good enough that you will want to let some other fellow go and give him the job. Or sometimes, there are good farmers among them and they will rent a farm on the halves" (USHR 1920:53). These last remarks are of special interest, since these probably best describe the circumstances by which many of the Bastrop tenant farmers were invited to settle in the area. The apparent bond between Osborn and Martínez, see Site History-Tenancy below, serves to exemplify such owner-tenant relationships.

Throughout the 1920s and well into the post-WWII years, Texas was the largest contributor of Mexican labor to the rest of the country, with El Paso, Laredo, San Antonio, and Fort Worth serving as staging areas. During this same period, this large pool of agricultural workers made cotton the premier industry in Texas, and the Mexican workers the laborers of choice (Vargas 1999:254). The above noted Mr. Roberts testified again on January 27, 1920, before the U.S. Senate (USS), Committee on Immigration. His statement most probably typifies the cotton grower's sentiment towards Mexican labor, and the history of this labor in the development of the State's cotton industry:

We are short of labor. The real fact is we have not any labor. Modern machinery has developed very rapidly and has made it possible for one man to cultivate a great deal of land, but there has been no development along the line of picking and chopping cotton. We pick cotton like we did a hundred years ago and we chop cotton like we did a hundred years ago, with the exception that in picking cotton we put it into a sack now where we used to put it into a basket. The greater part of Texas, or perhaps all that country west of the Colorado and south, has always been, and is today, dependent upon Mexican labor. We have always had free access to the Mexicans on the other side of the border, and we have always been going there for our labor. We have built up the institution of cotton growing there, and millions and millions of dollars have come into that country and developed it on the proposition of the labor at our door. We have never had any labor in that country except as it has been brought in from across the Rio Grande (USS 1920:3-4).

That the south Texas cotton growers were experiencing a shortage of labor around 1920 is not at all surprising. By the early-1920s, northern employers were aggressively recruiting Mexican workers. According to Vargas (1999:255), this out-migration broke a quarter-century monopoly on Mexican labor held by the Southwest farmers, railroads, and mining industries. This migration was intensified as a result of word of mouth testimonials, as the immigrant workers traveled back and forth. Montejano (1987) explains that, contrary to popular belief, the Mexican worker was not at all passive and in fact did strive to secure better-paying jobs and working conditions. Many of these workers were sensitive to treatment by Anglo farmers, and quickly developed a network that passed along favorable or unfavorable references of particular farms (Montejano 1987). In the case of Pedro Martínez and David García, both of these tenant farmers had worked for other Bastrop area farmers before settling in and working for T. C. Osborn for an extended period of time. Another point to be made and which will be further discussed below, is that the tenant farmers of Bastrop County included a large number of Mexican-Americans.

The population of the Texas farm areas at ca. 1920 can be sorted into three general categories: farm owners, tenant farmers, and farm laborers. This study considers the first two - the owners and tenants. By 1920, 55 percent of all Bastrop County farms were tended by tenant farmers, with the remainder being in the hands of owner-operators. A tenant farmer basically rented land and a house from the farm owner, and then proceeded to cultivate with his own seed, equipment, horses or mules, and his and his family's labor. In contrast, sharecroppers were basically laborers who were compensated by farm owners by means of housing and monthly rations in lieu of cash wages (Montejano 1987). Most sharecropper agreements were for halves or quarters, and in the case of Bastrop County, the norm was halves. Under a halves agreement, the sharecropper furnished his and his family's labor, and in return he was allowed to keep one-half of the profits resulting from the cotton cultivated on the acreage assigned them, that is, after the family paid off the accumulated debt resulting from the monthly rations. 


\section{Site Description}

This section describes the physical layout of the site, and is based almost entirely on a firsthand account by Pete Martínez, Jr. Figure 7 depicts the north end of the T. C. Osborn Farm at ca. 1930, and serves to demonstrate the relationship between the tenant farm (41BP314) and the G. W. Jones site (41BP86). The Jones site was investigated by Robinson (1989) and is clearly shown in Figure 7. All of the farm's dwellings, outbuildings, and stables were located in this area, and this was probably the case since at least 1906.

This site plan was achieved by locating the area on a geological survey map (USGS 1982). Once this section was isolated, we were then able to scan in the image and overlay two distinct site maps: the T. C. Osborn farm site map (John Clark's
1987 field map) and the G. W. Jones site map (Robinson 1989:19). These three images were then manipulated and corrected in order to arrive at a fixed scale. The final location of the homes, outbuildings, and service road were verified by referring to an on-site description given by Pete Martínez, Jr. (personal communication 2000). The focus of this report is the site located at the far west end of the farm; 41BP314, at the left side of the shaded area in Figure 7. The house and eastern extent of Pecan Street, which then became a service road that led east towards the main house, are visible.

Based on several accounts, we now know that the T. C. Osborn site (41BP314) and the G. W. Jones site (41BP86) were interrelated. Initially, the only structure associated with the $\mathrm{T}$. C. Osborn site was a simple four-room, board-and-batten, house that had all but fallen apart by early-1987. Pete

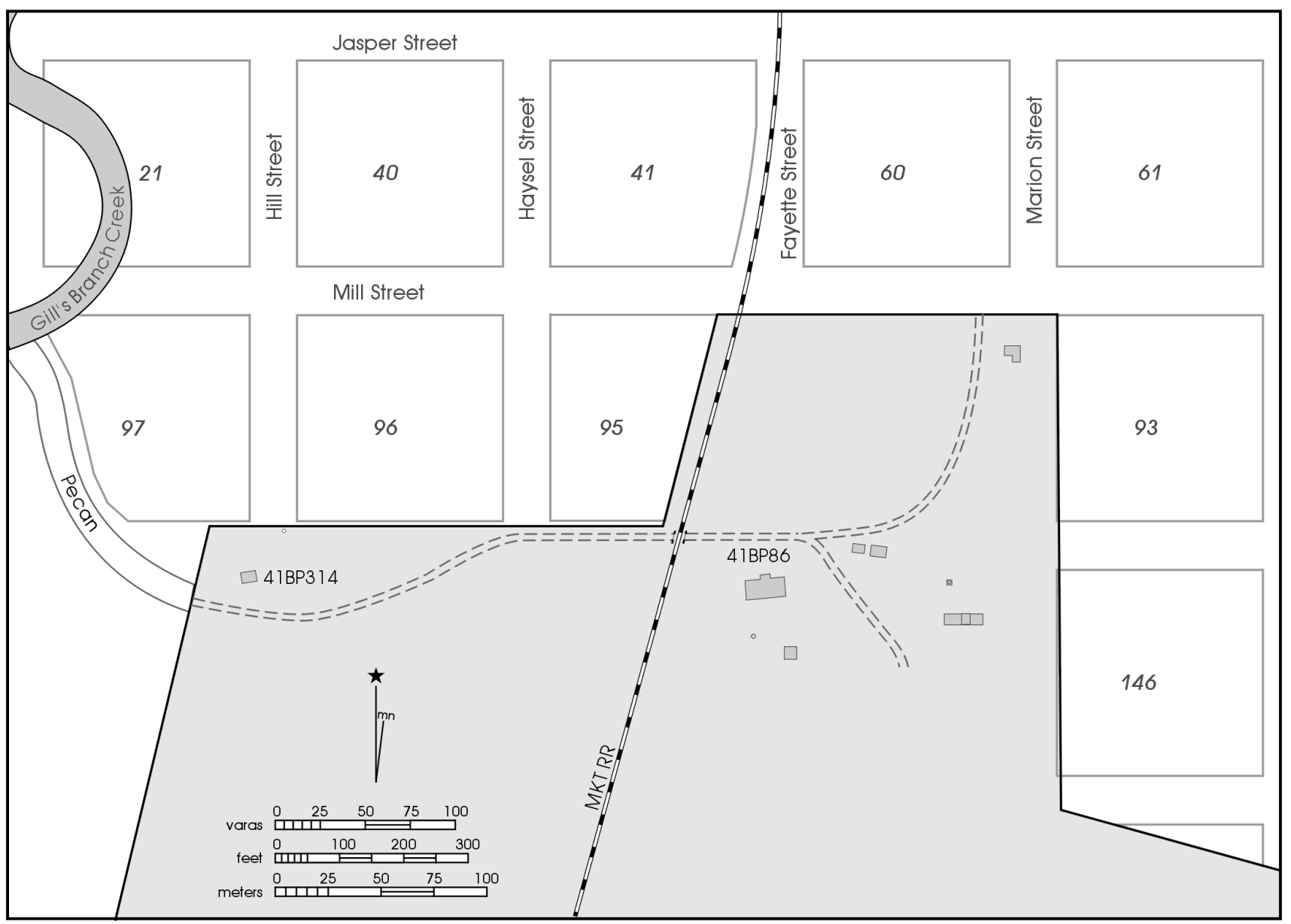

Figure 7. North end of Osborn Farm at ca. 1930. 
Martínez, Jr. provided the following account, as he and the interviewer drove through the area in December 2000:

Go up a little bit further and I'll show you where the house my uncle, that moved to Zapata, used to live in. See that house over there, that's... a man that used to be the pastor of the Baptist Church, Brother Bell, the one who used to have that school (the Mexican Baptist School). Brother Bell then sold his place to Cecil Long. Now, right about where that tree is where that house was [4IBP314]. And you see, that was cotton field there and this was cotton field here [looking towards the south and then east]. And you had a little road through there [looking to the east], and over to the right, as you crossed the railroad track, that's where the big two-story house was (Pete Martínez, Jr., personal communication 2000).

Throughout the Osborn ownership, between 90 and 100 acres of the total 327 acres was actually cultivated. This places the farm operation well within the norm. Table 5 presents and compares the farm acreage for Bastrop County between 1880 and 1940. As is obvious, the number of farms in the county that cultivated between 100 and 499 acres comprised almost a third of the total. However, it seems that the number of farms of between 20 and 49 acres was fairly large, and actually surpassed all others in 1900 . These smaller operations remained popular up until about 1940, when there was a dramatic decrease. This is most probably owing to the depressed economy and the inability of small operations to stay afloat.
Pete Martínez, Jr. went on to explain that Pecan Street, where it butted the west end property line, became a private service road that meandered to the east towards the tracks. He explained that as they approached the tracks from the west, they would open a gate, cross over, open and ride through a second gate, and then pass right in front of the main house (41BP86). The two structures seen in Figure 7, to the east of the main house, were a board-and-batten garage and a utility room. Behind and to the east of these structures was a double-pen log house that had been converted into a barn and corral. The single-pen log cabin was located to the rear of the main house. Off to the north, towards Marion Street, was the board-and-batten house where he was born. The following histories of ownership and tenancy will help to further clarify the overall logistics of the T. C. Osborn Farm.

\section{Site History - Ownership}

\section{Stephen F. Austin League (1832 to ca. 1838)}

As compensation for his efforts as an empresario, Stephen F. Austin received deed to two parcels in Bastrop County. Both parcels were along the east side of the Colorado River. One was located to the north of the town of Bastrop, and the other was located directly to the south and is the parcel of interest to this study. Stephen F. Austin passed away in 1836 at the age of 43 , and never did develop this land. Instead, his brother-in-law, James F. Perry, who was appointed executor of his estate, began selling Austin's League ca. 1838. He sold portions of the tract to Samuel R. Reid, William Pinkney Hill, and William Gammel, business and civic leaders of Bastrop, all of whom sold to Andrew Castleman within a couple of years.

Table 5. Farm Acreage, 1880-1940

\begin{tabular}{|l|c|c|c|c|c|c|c|}
\hline Census Year & $\mathbf{1 8 8 0}$ & $\mathbf{1 8 9 0}$ & $\mathbf{1 9 0 0}$ & $\mathbf{1 9 1 0}$ & $\mathbf{1 9 2 0}$ & $\mathbf{1 9 3 0}$ & $\mathbf{1 9 4 0}$ \\
\hline $\mathbf{1 0}$ acres & 38 & 39 & 60 & 49 & 41 & 60 & 92 \\
\hline $\mathbf{1 0 - 1 9}$ acres & 239 & 96 & 153 & 96 & 76 & 154 & 217 \\
\hline $\mathbf{2 0 - 4 9}$ acres & 768 & 564 & 1,248 & 950 & 960 & 940 & 405 \\
\hline $\mathbf{5 0 - 9 9}$ acres & 314 & 387 & 838 & 802 & 1,038 & 889 & 592 \\
\hline $\mathbf{1 0 0 - 4 9 9}$ acres & 763 & 837 & 1,103 & 1,106 & 1,118 & 1,050 & 1,142 \\
\hline $\mathbf{5 0 0 - 9 9 9}$ acres & 75 & 88 & 64 & 56 & 64 & 63 & 108 \\
\hline$>\mathbf{1 0 0 0}$ acres & 34 & 58 & 43 & 37 & 28 & 51 & 48 \\
\hline Total Farms & 2,231 & 2,069 & 3,509 & 3,096 & 3,325 & 3,207 & 2,604 \\
\hline
\end{tabular}

Note: Unable to include 1950 data -number of acres per farm was varied greatly from previous census years. (U.S. Historical Census Data Browser 2000). 


\section{Andrew Ewing Castleman Family}

(ca. 1840 to Dec. 1855)

Castleman was originally from Tennessee and may be the same Andrew Castleman that was granted land in 1828, where the town of Plum, Fayette County, was later founded (Handbook of Texas Online 2000). If this is the same person, it seems that Castleman may have been in Texas briefly, then returned to Tennessee to marry, returned again to Texas ca. 1840, sold his land in Fayette County, and immediately relocated to Bastrop County. In 1840, Castleman purchased part of the Austin League from three different owners: Samuel R. Reid, William P. Hill, and William Gammel. Castleman first appears in the Bastrop County Tax Rolls of 1840 and then again in 1841 (RootsWeb.com 2000). He is also listed as an Alderman of Bastrop in 1845 (Kesselus 1986). He, his daughter, and three sons appear in the 1850 Census of Bastrop County. Except for his nine-year old son, born in Texas, the other children were all born in Tennessee. His oldest son, R. Castleman, was born ca. 1835 and his youngest was born ca. 1841 in Texas. This suggests that he married and started his family in Tennessee ca. 1834, and then relocated to Texas in ca. 1840. A record for Nancy Reding Castleman, wife of Andrew E. Castleman, was located in the county's cemetery records. She was interred at Fairview Cemetery, and according to her grave marker, she came to Texas ca. 1840 from Davidson County, Tennessee, and died sometime prior to 1845 (Figure 8).

In 1850, Castleman is listed as a 47-year-old farmer with a net worth of $\$ 1,000.00$ (RootsWeb.com 2000). Castleman

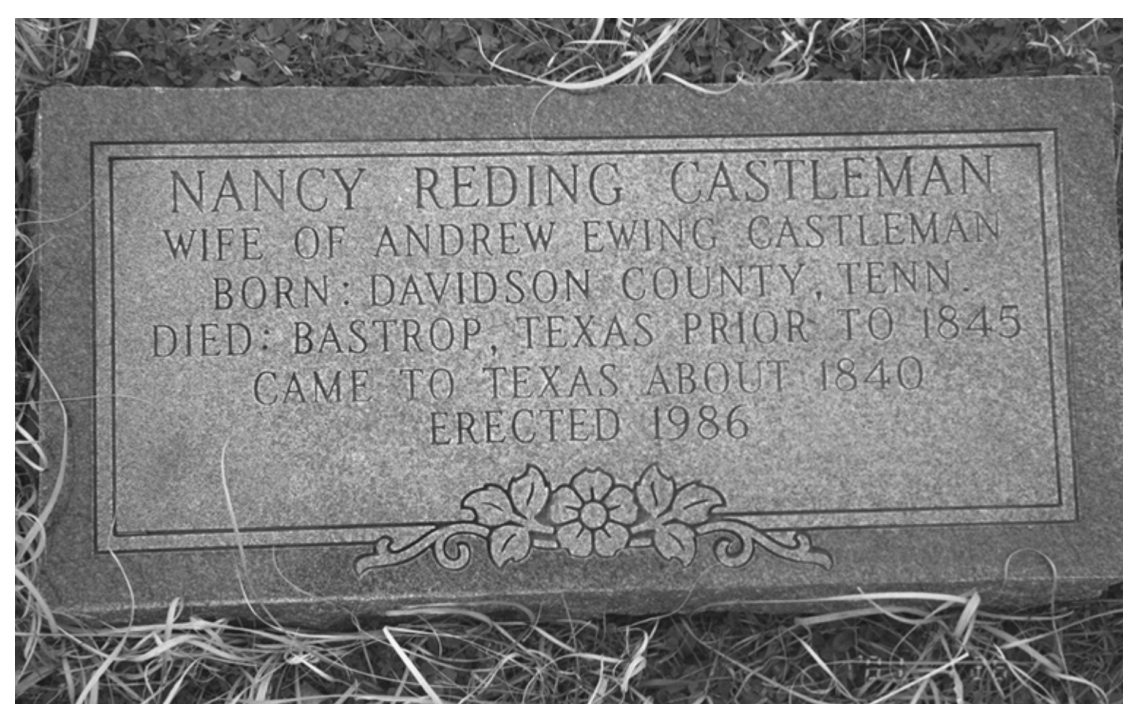

Figure 8. Grave marker of Nancy R. Castleman. is also listed in Schedule 2 of the Slave Inhabitants for 1850, as owning eight slaves: a 50-year-old Black female; a 42year-old Black male; a 30-year-old Black female; a 23-yearold Mulatto female; a 10-year-old Black female; a 7-year-old Black male; a 5-year-old Mulatto female; and a 4-year-old Black male (USDCc 1850:74). No other information such as names and place of origin is provided. The above information suggests that Castleman lived on the property, most probably in the two-story house shown in Figure 7. His slaves may have occupied the single- and double-pen log cabins located at the rear of the house. This scenario is not at all unlikely given the following narrative by James Jackson, an ex-slave.

He tuk us to Bastrop County and sold us to Doc Duvall. Marster Duvall sold my brother right after he bought us, but me and John, we stayed wid him till de slaves was freed. On Marster Duvall's plantation de slaves all lived in log cabins back of de big house. Dey was one room, two rooms and three room cabins, dependin' on de size of de family. Most had dirt floors, but some of 'em had log slabs (RootsWeb.com 2000).

Pete Martínez, Jr. recalled having overheard "the older people" say that the single-pen log cabin had long ago been used to house slaves. Considering these details, it stands to reason that Castleman was responsible for constructing the "big house" and log cabins. This idea is further supported by a neighborhood survey completed by Texas Historical Commission staff between 1976 and 1977. The survey's data sheet indicated that the house was constructed ca. 1848. This same survey described the house as a two-story wood frame, salt boxshaped, rectangular plan, with a central hall, stairs, and three chimneys. The inventory also included mention of a double-crib log cabin, a smaller log cabin that served as a kitchen, and a brick-lined well (Texas Historic Site Atlas 2000). Robinson (1989) suggested that the house was constructed ca. 1855 , when George W. Jones purchased the land from Castleman. It now seems much more likely that Castleman constructed the double-pen and single-pen $\log$ houses ca. 1840 , for his family and 
slaves, respectively. The large two-story house was probably constructed ca. 1848, which would have allowed the slaves to utilize the double-pen log house soon after. It would appear that between 1850 and 1855, the Castleman Family was quite comfortable and sharing in the county's prosperity during this decade.

Finally, after having farmed in Bastrop for 15 years, Castleman sold his farm to George W. Jones. Andrew Castleman most probably left the county after selling to Jones in 1855, but it seems his oldest son remained in Bastrop. A review of the 1860 Census failed to locate Andrew Castleman, but did locate R. M. Castleman, a 25 year-old clerk from Tennessee (USDCb 1860). Why Andrew Castleman decided to sell and leave remains a mystery, although a close examination of the local paper during this period might shed some light. It seems that R. M. Castleman did not remain either, since Nancy Reding Castleman is the only Castleman interred in Bastrop County (RootsWeb.com 2000).

\section{George Washington Jones Family}

(Dec. 1855 to May 1906)

In 1855, George W. Jones purchased five parcels from Andrew E. Castleman, in consideration of the sum of $\$ 1,000.00$. The first three parcels consisted of 12.5 acres each, or 37.5 acres, and all were described as being part of Austin's League and south of the town tract. The remaining two lots consisted of "fractional blocks" of unspecified acreage, referred to as Block 143 and Block 144 (BCC, vol. K:28). In addition, and as described above, Castleman deeded Jones a fairly well established farm operation.

A review of the 1860 Census for Bastrop County failed to locate either George W. Jones or his wife. We know that he was in the county, since he was serving as the Bastrop County District Attorney between 1856 and 1861, and then left to serve in the Confederate Army from between 1861 and 1865. It is very likely that he and his wife may have been away visiting when the Census was completed. However, Jones is listed in Schedule 2, Slave Inhabitants for 1860, as owning six slaves, but this information may have been secured from the slaves themselves. The schedule lists: a 40-year-old Black male, a 45-year-old Mulatto female, a 17-year-old Black female, a 17-year-old Black male, a 12-year-old Black male, and an 8-year-old Mulatto female. The schedule also notes that there was one slave house, most likely the double-pen $\log$ house. As was the case in the 1850 Census, information such as names and place of origin was not given.

The 1900 Census of Bastrop County listed G. W. Jones as living on a farm, with his wife and nephew. The schedule notes that G. W. Jones, a 71-year-old, was a White male, born September 1828 in Alabama. It also indicates that his father was born in Virginia and mother in North Carolina. His wife, Ladora S. Jones, is listed as a 64-year-old, White female, born July 1836 in Mississippi; her father was born in Mississippi and her mother in Tennessee. Also listed as being part of the household is Jimmie S. Jones, nephew of the head of house, and a White single male, born March 1876 in Texas, and noted that his father and mother were both born in Tennessee. The occupation of both G. W. Jones and Jimmie are listed as lawyers. An extensive biographical sketch of G. W. Jones (1828-1903) can be found in the Handbook of Texas Online and in the Jones site report (Robinson 1989).

\section{Thomas Claiborne Osborn Family (May 1906 to ca. 1985)}

Thomas Claiborne Osborn and his family lived in town at 1102 Hill Street, and never occupied their 327-acre farm south of town. T. C. Osborn was born August 12, 1850, not far from Bastrop in the small community of Hog Eye (present-day Elgin). As noted earlier, he was the son of Thomas Osborn and the grandson of Benjamin Osborn, who came to Texas as a colonist with Stephen F. Austin in 1825.

Benjamin Osborn and his wife, Leah Stark, originally from Tennessee, first migrated to Mississippi and then on to Matagorda, Texas in December 1825. Their second oldest son, Thomas Osborn, married Mary Augustine McCullough on May 2, 1841 and they had nine children; Thomas Claiborne Osborn was their oldest son (Gore 1979; Handbook of Texas Online 2000).

Beginning in 1871, T. C. Osborn made seven trips up the old cattle trails to Kansas and Nebraska, and recalled traveling no more than 12 miles per day (Taylor 1934). T. C. Osborn married Suzanna Isabel (Belle) Smithwick on October 20, 1878. Belle Smithwick was also born in Bastrop County at Gravelly on Alum Creek; her father was Alex A. Smithwick of Mississippi and her mother was Mary Jane Cartwright of Tennessee. In September 1880, T. C. and Belle Osborn bought the south half of building block 30, east of Main Street, and built their home in 1881 (BCC, vol. 1:417; 
Gore 1979). The lumber for the house was hauled in a wagon from a nearby mill in McDade. T. C. Osborn, his wife, and their two daughters lived on Hill Street the rest of their lives (Gore 1979). His daughter Mary was born May 1880 and his daughter Kathryn was born in October 1883 (USDCd 1900). Mary never married, nor did she have any children.

It seems that throughout his lifetime, T. C. Osborn was involved in various business ventures. Aside from the noted "G. W. Jones Farm," evidence of two other enterprises was located. The 1880 Census of Manufacturers lists T. C. Osborn and C. W. Cartwright as owning and operating a butcher shop. The data indicates that they employed an average of three men, and that they worked 11-hour days from May to November, and 9-hour days from November to May. The total outlay in wages was $\$ 400$ per year; they slaughtered about 150 head of beef per year, with an average gross weight of $600 \mathrm{lbs}$.; they also slaughtered about 5 hogs per year, with an average weight of $200 \mathrm{lbs}$; ; and the total value of their products was reported as being \$2,100 (USDCa 1880). A brief note in the Bastrop Advertiser (November 24, 1883) announces: "Messrs. Osborne and Cartwright have sold their market business to Mr. John Kohler, who takes charge next Monday." Evidently, Osborn and Cartwright continued as partners, possibly in a saloon. A mechanic's lien of 1886 details the construction of a two-story brick building on Lot 4, Block 5 in Bastrop at a cost of $\$ 4,700$. The contractor is William Thaison of Austin (BCC, vol. 1:13). In addition, the 1900 Census for Bastrop County lists Osborn as "owner of saloon" (USDCd 1900). In a seemingly entrepreneurial gesture, T. C. Osborn adds farming to his enterprises. In 1906, in consideration of the sum of $\$ 2,000$, T. C. Osborn purchased four parcels of land and the "G. W. Jones old homestead tract," from J. S. Jones, executor of the Jones estate (BCC, vol. 41:130).

T. C. Osborn passed away March 19, 1939 at the age of 88 years; his daughter Mary passed away May 15, 1952 at the age of 72 years; and his wife Belle passed away on February 1, 1955 at the age of 97 years. Mrs. Mary Belle Turner Gore recalls that her grandparents were able to celebrate their sixtieth wedding anniversary a year and a half before T. C. Osborn died. Kathryn Osborn Turner passed away on October 24, 1963 at the age of 80 years.

Kathryn Osborn Turner sold the Osborn homestead in 1955, soon after the death of her mother. The Osborn Farm, however, was left to Kathryn's daughter, Mary Belle Turner Gore
(BCC, vol. 13:106-108). Mrs. Gore and her husband, Walter Gore, were local school teachers.

\section{Site History - Tenancy}

It is unlikely that T. C. Osborn ever worked the farm, preferring instead to bring in tenant sharecroppers. After his death in 1939, management of the farm fell into the capable hands of his unmarried daughter, Mary. According to Pete Martínez, Jr., Mary Osborn managed the farm until ca. 1950, after which time they begin to lease out the land exclusively for pasturage. Both Kathryn Osborn Turner and her daughter, Mary Belle Turner Gore, continued this practice until selling the land in the mid-1980s.

The history of site tenancy presented here indicates that $\mathrm{T}$. C. Osborn had at least two tenant families at 41BP314 (and another two at 41BP86). In considering the data, it will be obvious that three major gaps in tenancy exist. The first and second occur before and after the González tenancy (190611 and 1922-31), and the third occurs after the García tenancy (1942-52). Excepting the apparent uninterrupted accumulation of artifacts, no other evidence of occupancy (i.e., occupants) was located. Considered in their entirety, the artifact assemblage suggests a site occupation of between ca. 1900 and 1950.

\section{Livorio V. González and Rosario Domínguez González Family (ca. 191 1-1922)}

According to Pete Martínez, Jr., one of the earliest families that lived at 41BP314 was his uncle, Livorio "Lee" González and his aunt, Rosario Domínguez González (his mother's sister). This family lived at the site at least until the early 1920s. This is all according to what his parents had told him, and they also mentioned that they relocated to Zapata County, where Livorio took a job with a State road maintenance crew.

The county marriage records indicate that Livorio V. González and Rosario Domínguez were married by Rev. T. M. Lennartz, a Catholic priest, on January 1, 1911 (BCC, vol. J:231). The Bastrop County birth records revealed that Livorio González, a farmer, and Rosario González, a housewife, had three children, and that both Mr. and Mrs. González were from Zapata County. According to Pete Martínez, Jr., the Domínguez family had traveled north in the early-1900s. He recalls his mother telling him that they traveled north by wagon. Her father would stop and work along the way, to 
earn just enough money to buy the newborn baby some milk, since it couldn't be breast-fed. Livorio and Rosario González had three children while at this farm. The first-born was Sara, a female, born August 7, 1912 (BCC, vol. 16:575); then Leobardo, a male, born March 1, 1920 (BCC, vol. 3:18); and then Amelia, a female, born July 21, 1922 (BCC, vol. 16:576). Dr. H. B. Combs was the attending physician for all three births.

On November 5, 1942, Sara and Amelia González returned to Bastrop to register their births. The above-cited birth certificates were recorded on this date, with Pedro Martínez and E. J. Rabensburg (local grocer) signing the affidavits. Unfortunately, Pete Martínez, Jr. didn't know much else about the González family, since they lost contact many years ago.

The beginning and ending dates of occupation for the González family are based on the couple's marriage in 1911, and the birth of the last child born in Bastrop in 1922. However, it is possible that their stay on the Osborn Farm might have begun before 1911 and could have continued for some time after 1922. As noted previously, we were unable to determine who might have occupied the tenant house (41BP314) between ca. 1922 and 1932.

According to Pete Martínez, Jr., the next known tenants of 41BP314 were David García and his family, back in the $1930 \mathrm{~s}$ and 1940s. He recalls that the family moved out before the end of the War, since he distinctly remembers the troop trains going by and the family still living at this house.

\section{David García and Louise Rodríguez García Family (ca. 1932-1941)}

David García passed away in 1983, at the age of 86 years. His 93-year-old widow, Louise García, was located and found to live within four blocks of the site. Mrs. García and her daughter, Emma Rockwell, who was visiting from West Virginia, were interviewed in December 2000. Unless otherwise noted, the following information was obtained from the interview summaries.

Mrs. Louise García's parents were Perfecto Rodríguez of Galeana, Nuevo León, Mexico and Julia Ríos Rodríguez of San Diego, Texas. Her father was a sharecropper on the Fitzwilliam Farm, southwest of Bastrop. Mrs. García and her four sisters (no brothers) helped in the fields from the time they were five years old. She never knew her paternal grandparents, but did get to meet her maternal grandfather,
Macedonio Ríos. Her grandfather was a farmer, who lived and worked in Bastrop and Cedar Creek. In 1911, Macedonio Ríos and others, acting as "trustees of the Mexican community, west of the Colorado River," purchased a parcel of land to be used as a graveyard, church, and school. The property was located about two miles south of Cedar Creek Store, a few miles east-southeast of Bastrop (BCC, vol. 50:32).

Louise Rodríguez García was born February 7, 1907 in Bastrop County, in the nearby coal mining community of Phelan. Her father's cousins, who were already working in the local mines, lured him away from Mexico. He left the mines after finding work on a nearby farm. All of Louise Rodríguez García's brothers died in infancy, and her sisters have all now passed away. Her oldest sister, Nemesia, was born October 1892 in Columbus, Texas. Her husband, David García, was born in Mexico, and Mrs. García believes he may have been from Villa Acuña, Coahuila, Mexico, across the border from Del Rio, Texas. His parents were Felix García and Arcadia Villalobos García; they worked in the area for a while and may have eventually returned to Mexico (BCDR, vol. 18:195).

David García and Louise Rodríguez met at the Mexican Baptist Church and were married there on July 3, 1925 (BCC, vol. N:373). Mrs. García's older sister Nemesia, mentioned above, was married to Samuel García (David's brother). Prior to their move to the Osborn Farm, David and Louise García lived in town, and Mr. García worked for the county road crew. According to Mrs. García, her husband longed to get back to farming-tenía ganas de volver al rancho-so he took the job with Mr. Osborn. Their oldest daughter, Emma Rockwell, nee García, born in 1927, offered a clear recollection of her childhood at the Osborn Farm, where she and three other siblings grew up. There were two more children born after the family moved off the farm.

Emma Rockwell described her father as a farmer who worked for Mr. Osborn for nine years. She recalled that Asención Domínguez and Pedro Martínez were also sharecroppers on the Osborn Farm during their tenure. She believes her family moved into the Osborn tenant house when she was five years old (1932), and moved out when she was 14 years old (1941). From what she recalled, her father farmed about 10 acres of cotton, and some corn. He and Tom Osborn would go "half-and-half" on the cotton proceeds, but she couldn't recall what they did about the corn. 
Mrs. Rockwell was able to describe the house, rooms, work areas, and outbuildings. These descriptions were used to edit the measured drawings presented in the Artifactual Data (architectural) section of this report. Both Mrs. García and Mrs. Rockwell recalled the fireplace along the west elevation of the house, and recalled having used it. In the kitchen, they used a wood-burning stove- una estufa de leña. They also had a wood-burning heater in the house, but rarely used it since the fireplace was more than adequate. Mrs. Rockwell had no knowledge of what Feature 1, a shallow pit, might have been. She did, however, recall a small barn or shed, located about $40 \mathrm{ft}$. behind the house. This shed was oriented with the gable ends to the east and west, just like the house, and the entryway was located on the east end. Based on Mrs. Rockwell's description, we imagine that this shed would have been located between Units N575/E465, N555/ E480, and N580/E500. This is also where they kept the chickens. Although they did have a milk cow, it was kept in the community barn (double-pen log house) next to the twostory house (41BP86). All the farm animals and equipment were kept in the barn by the two-story house, which was accessible to all the Osborn Farm sharecroppers. As for the "missing" privy, Mrs. Rockwell recalled it being located about $100 \mathrm{ft}$. to the north of the house and towards the creek. This would place the privy within $40 \mathrm{ft}$. of Unit N615/E490 (see Figure 5).

The worst catastrophe that Mrs. García and Mrs. Rockwell could recall was the June 1935 flood, caused by intense rainfall and flooding of the Llano, Pedernales, and Colorado rivers (National Weather Service Southern Region 2000). The family was forced to leave their house and take refuge with the Martínez family at the two-story house. The flooring of the tenant house warped in places and most of their belongings were destroyed. Some area families had their entire homes washed away. The American Red Cross came in and helped the Bastrop community with clean-up efforts, provisions, and vaccinations. Pete Martínez, Jr. recalled the 1935 flood: "I can remember my sister having me in her arms, rocking me in a rocking chair at the house, and daddy worried. He's trying to decide, 'Are we gonna move to higher ground?' His plan was to go up there to the cemetery, to that hill, to the right of the cemetery [Alta Vista Cemetery]." The river's water level finally receded and the Martínez and García families stayed in the two-story house.

There were many buttons recovered from within and behind the house, as a result of the 1987 excavations. Mrs. García mentioned that they used to wash and hang their clothes out to dry out back. She washed their clothes on a washboard - a puro tallador - and hung them out to dry on a line. Except for the chickens out by the barn behind their house, they didn't keep any livestock. Mrs. Rockwell recalled her father having a small, five-foot square vegetable garden near the barn. She also recalled having played with, and broken, many bottles, especially some dark blue bottles that they often came across scattered about the property.

David García finally gave up farming in 1941 and took a steady job at the local IGA Store, where he worked for 20 years. After retiring from the IGA Store, he took custodial jobs at the county courthouse and at a local bank. Mrs. García recalled someone having moved into the tenant house after they left in 1941, but couldn't recall the family's name.

\section{Sharecropping as an Institution Oral Narratives}

The concept of farm tenancy and sharecropping can be best understood through the following notes and explanations, presented in the form of firsthand accounts. Figures 9a-e are submitted as graphic representations (a tiny sample) of some of the work involved. Most of these photos were taken during the period under study, but involve scenes from throughout Texas.

A total of three persons from three distinct families were interviewed for this project. The following narrative is based almost entirely on the testimonial of these individuals. Wherever possible, the data was corroborated by archival records (as cited). The strength of these accounts lies in the fact that two of the three informants (Emma Rockwell and Peter Martínez, Jr.) brought forth their personal knowledge and experience of having lived and worked on the Osborn Farm. The third informant, Mr. José Barrón (95 years old), is just as important due to his accumulated experience, and his accounts are presented first.

\section{José Barrón (born May 29, 1905)}

Mr. Barrón was born on a farm in Travis County on May 29,1905 , and could no longer recall the farm owner's name. His father, Santos Barrón (1874-1935), was born in Taylor, Texas and his mother, Beatrice Serna, was born in Eagle Pass, Texas, and was about 80 years old when she passed away in 1957. The Bastrop County death register notes that Santos Barrón was a 64 year-old farmer, born in Texas to Phillip and Florentina Barrón of Mexico. Santos Barrón is 
interred at Alta Vista Cemetery, and Beatrice Serna is interred at Hollywood Cemetery in Houston.

When Mr. Barrón was about 12 years old (1917), his parents moved from Travis County to Bastrop County in order to sharecrop in this area. There were a total of nine in the family: his parents and seven children. Mr. Barrón couldn't recall the farm owner's name, but does recall his uncle, Vicente Serna, was also there. Besides Vicente, he recalled that he also had a couple of paternal uncles and aunts living in Bastrop County; they were José and Abelino Barrón, and Francisca and Angelita Barrón. Although he and his family never visited Mexico, Mr. Barrón does recall his mother's family coming over to visit them in Bastrop. They have all long since lost contact with her family, since she passed away some 43 years ago.

Mr. Barrón recalls that several families lived and worked on the same farms. The number of families on a farm depended on the size of the place - según el rancho del amosometimes two, three, or four families. Mr. Barrón had three brothers and three sisters, and recalled that the entire family pitched in wherever they could. Their father was the planter, or sembrador, and the children provided the labor during the harvest—piscaban la cosecha.

Throughout the year, the landlord, or amo, would advance his father a monthly allowance, for groceries and other incidentals. He and his family purchased their groceries, mostly on credit, from Rabensburg Grocery in Bastrop. When they were in need of medical attention or needed a baby delivered, most Mexican families went to see Dr. Combs, while others used midwifes, or parteras. Mr. Barrón's children, Rudy and Enedina, were both delivered at home by a midwife, from what he recalls, who may have been Mrs. Espinoza.

When the cotton was finally harvested and sold, the landlord and his father would split the profits fiftyfifty_ibamos a medias. In the early1900 s, cotton sold for $\$ 50$ per 500 lb. bale. From his share, his father would pay back the landlord the money he had been advanced throughout the year. Most often, the amount paid back amounted to his father's entire share. In the case of the corn crop, his father kept the entire profits. Mr. Barrón's father typically cultivated about 60 acres of cotton and between 30 and 40 acres of corn.

Mr. Barrón couldn't recall how long his family lived on the farm near Utley, but does recall they moved around from one place to another. In 1935, the year his father passed away, he and his brother Adolfo came over to Bastrop to work as day laborers for Will Watson. When his father passed away, his mother went to live with one of his brothers in Houston. Prior to 1935, he had worked for his father, who sharecropped around Bastrop. He and his brother stayed on for a year with Will Watson and then moved on to work for John Allen until about 1945, when he took a job as a custodian with the Bastrop School District.

In 1934, Pascual Hurtiz, a Mexican Baptist minister, officiated at the wedding of José Barrón to Virginia Galván of Bastrop. Mr. Barrón and his bride met as a result of their families working on neighboring farms. Her father was Pedro Galván, originally from Mexico, possibly Piedras Negras, and her mother was Joaquina Rodríguez Galván of Bastrop. Joaquina Galván was a 85-year-old housewife, born in Texas to Santiago Rodríguez and Felicitas Ramos of Mexico. According to the Bastrop County death register, Pedro Rivera Galván, a farmer from Mexico, passed away at the age of 85 .

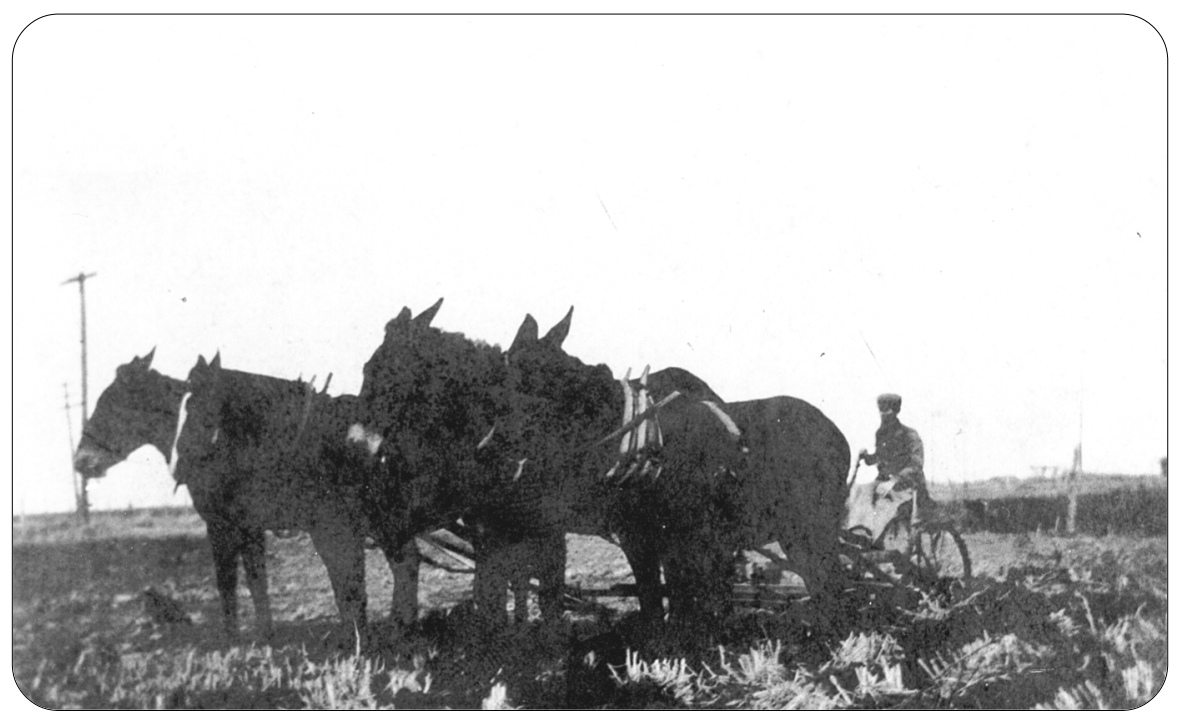

Figure 9a. Mule-drawn plow. (ITC-UTSA, No. 86-176) 


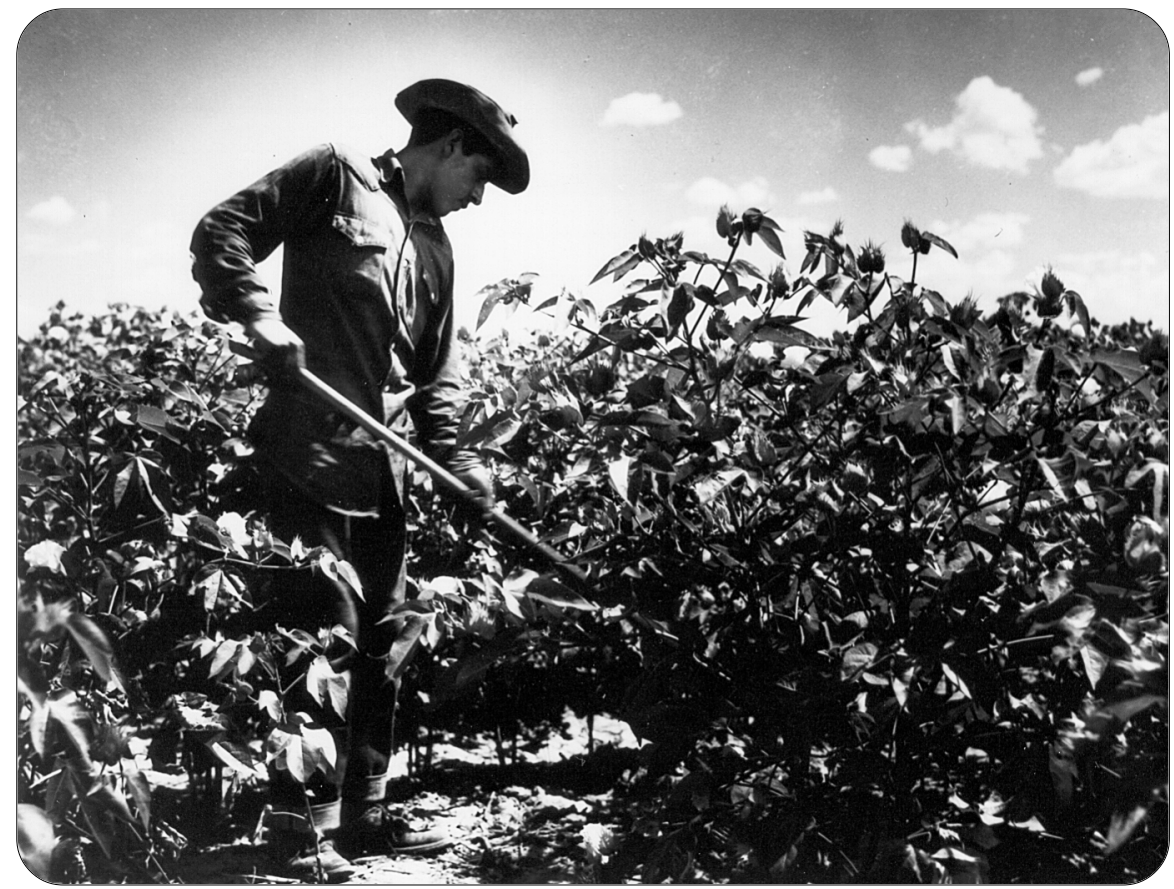

Figure 9b. Weeding cotton near El Paso, Texas. (ITC-UTSA, No. 75-963)

Most families were spread throughout the county, living and working on different farms. There was a big dance hall in Phelan, and he and his brothers had an orchestra that usually provided the music. The orchestra didn't have a name; they were just referred to as Los Barrones. Mr. Barrón played the 12-string bass, or bajo sexto. The orchestra also had a guitar, drums, violin, clarinet, and flute.

\section{Emma Rockwell}

(born February 23, 1927)

Mrs. Rockwell recalled her father was a farmer who sharecropped for T. C. Osborn from 1932 to 1941 . Her father's share was fairly small, not more than 10 acres, which he planted

Mr. Barrón and his wife had two children: Enedina, who lives in Austin and is married to Pete Martínez, Jr., and Rodolfo "Rudy" of Bastrop, married to Dolores Coy Barrón.

Although he never attended school, Mr. Barrón was taught English while residing and working on a farm near Utley. He recalls having to cross the Colorado River on a skiff, or esquifa, in order to get to the ranch school, or escuela de rancho, where a young lady by the name of Nelle Schaefer taught English. Nelrose Esma "Nelle" Schaefer was born in Bastrop County on August 14, 1900, to John J. Schaefer and Lillie Doss Schaefer (BCC, Index to Births). The 1900 Census for Bastrop County lists Johnny Schaefer and family living on Farm Lot 1, Justice of the Peace Precinct 1. Schaefer, whose parents were born in Indiana, is listed as being 32 years old, born March 1868, in Texas. He is listed as a "bartender" and has his wife and two sons living with him. (Nelle was born a couple of months after the 1900 Census was completed.) Schaefer's wife, Lily, was 24 years old, born in Texas, with her father born in Germany and mother unknown. He had a son, Claborn [sic], born May 1896 and another, Harold, born August 1898.

Mr. Barrón recalled there being a lot of Mexican and Mexican-American families working and living in Bastrop County back then, and many of them worked the coal mines in Phelan. The coal miners and sharecroppers would get together on weekends to celebrate all sorts of occasions. mostly in cotton, and some corn. Her father and T. C. Osborn would split the cotton proceeds, fifty-fifty.

Mrs. Rockwell recalled that the children helped in the fields from a very young age. She noted that few sharecroppers could afford to hire people. "People would get paid depending on the amount, or weight, of the cotton picked. Most had to use the immediate family." She suggested that if you managed to bring in a bountiful crop, you might hire people then, but Mrs. Rockwell couldn't recall a time when her father had hired outside help. "We, the families, had to do it in order to keep the money within." Mrs. Rockwell recalls having been around seven or eight years old when she went out into the fields to help. "I went to school, but then I had to come and help after school." She continued helping for as long as her father had the farm (ca. 1941), which is when she was already in high school.

"My grandfather [Perfecto Rodríguez] as a farmer, made a trip via horse-drawn carriage, usually on a monthly basis, into Bastrop to get the groceries. Mother said there were no frills - ningún carinito - on the grocery list. Meat, flour, beans, rice, coffee were about it. My grandmother, Julia Rodríguez, worked as housekeeper for the landlady, Nell Fitzwilliam, who paid her a few dollars plus cheese, butter, and milk. My grandmother made the clothes for her four daughters: Nemesia, Santos, Luisa [Louise], and Raquel. A similar pattern was repeated in our family: My father would 
go to town on weekends to buy the groceries which were bought on credit, so were the shoes and clothes. These accounts were settled as the cotton crop was gathered in the summer. We liked the summer season, as we could put our hands on a nickel here and there to buy an ice cream cone. Mother, like my grandmother, made the clothes for us. My dresses cost 25 cents $-2 \frac{1}{2}$ yards at 10 cents a yard. But 25 cents were not easily available. I recall that canned milk was a must for my brother, Homer, a baby in 1942. So I found a job washing dishes for a lady who paid me 50 cents a week. I did this work en route to school. It only involved about 30 minutes. The pay covered the cost of the milk: 12 cans at 4 cents each equals 48 cents."

Emma García (Rockwell) attended school across the railroad tracks off of Main Street (ca. 1933-41). The school is gone now. The Mexican children went up to the eighth grade at this school and, if they wanted, they could attend high school with the Anglo children, but few did. "I was the first Latina that went to the Anglo school" (high school, 194144). Prior to desegregation, Mexican children that wanted to attend high school had to do so out-of-town. Mrs. Rockwell recalls that, "We were five Latinos that went from that elementary school [to the high school] ... I was the only one that graduated from that group, with that class." Emma García graduated in 1944 in a class of fifteen. After graduating from high school, she went to work at nearby Camp Swift for three years, in order to earn enough money to attend college. She then enrolled at Southwest Texas State University in San Marcos. She studied liberal arts, moved north before graduating, and attended other schools up north. She eventually went into the U.S. Foreign Service and worked in various embassies abroad, in Europe and Central America.

Returning to the topic of schooling in Bastrop, Emma recalled the landmark school desegregation case of Delgado vs. Bastrop I.S.D (1948). The plaintiff, Minerva Delgado, was her cousin. Mrs. Rockwell's aunt, Nemesia García, lacking any formal education, insisted that her adopted daughter, Minerva Delgado, be allowed to attend elementary school with the Anglo children, and not have to trek clear across town to the "Mexican" school. The school district didn't allow this so her aunt enlisted the help of the renowned Civil Rights Attorney Gus García of San Antonio, who came in and fought on their behalf. The U.S. District Court ruled in their favor and ordered that the schools be desegregated by September 1949 (Handbook of Texas Online 2000).

\section{Pete Martínez, Jr. (born October 6, 1932)}

Pedro Martínez and Lucrecia Domínguez were married on December 3, 1916 by Rev. Otto Bauer, a Catholic priest (BCC, vol. L:296). Sometime ca. 1917 they came to work for T. C. Osborn and stayed on until 1954. The family of Pete Martínez, Jr. lived at the two-story Jones house, the third house they lived in while working for T. C. Osborn. When his father first went to work for Mr. Osborn, the family had to stay in the small $\log$ cabin located directly behind the two-story main house (G. W. Jones House, 41BP86). This was all that was available at that time. Mr. Martínez doesn't think his family lived in this log cabin very long, and soon moved into a frame house a short distance from the two-story house. This second house was located at the south-end of Marion Street, east of the railroad tracks, and a short distance to the northeast of the

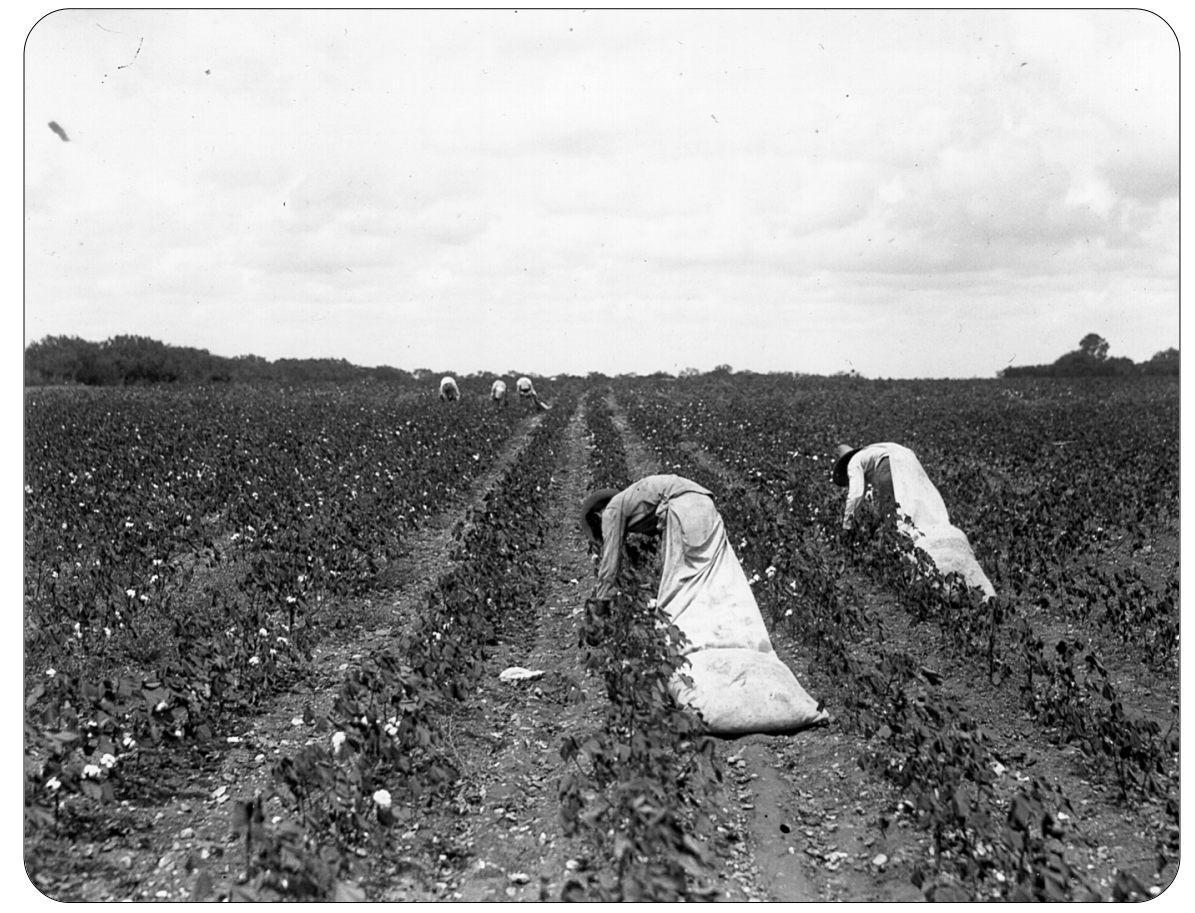

Figure 9c. Picking cotton, Bexar County, Texas. (ITC-UTSA, No. 1238-B) 
two-story house (see Figure 7). Pete Martínez, Jr. was born in 1932, in this house off of Marion Street. His family moved into the two-story house sometime around 1938 when his uncle, Asención Domínguez, moved out of this two-story house and away from the farm. Mr. Martínez stated that Mr. Osborn said to his father, "Peter move, I want you to move from the little house to the two-story house." He [Mr. Osborn] "worshipped his mules, cause that's what brought him his milk and butter. He said, '[Peter] you can be close to the barn where you can keep an eye on everything at night, and you can be close to my mules in case anything should happen." Mr. Martínez recalled that T. C. Osborn had a total of nine mules, which were grazed in the forested east end of the property.

Pete Martínez was a sharecropper, "The way my daddy did it, all the time I knew him, from the time I was born until the time he quit - the landlord provided the land, the seed, and the mules and plows. He [the owner] furnished everything. The only thing you furnished was your work. You and your family got out there and worked for him. I imagine my daddy farmed a good 80 acres, maybe a little more, and by 1940 could count on the assistance of three teenaged sons. Like I said, your landlord furnishes everything. You've got a place to live that doesn't cost you anything. You don't have any plumbing, any running water, but whatever it is, you don't pay nothing. When you go to harvesting your crop, you pick

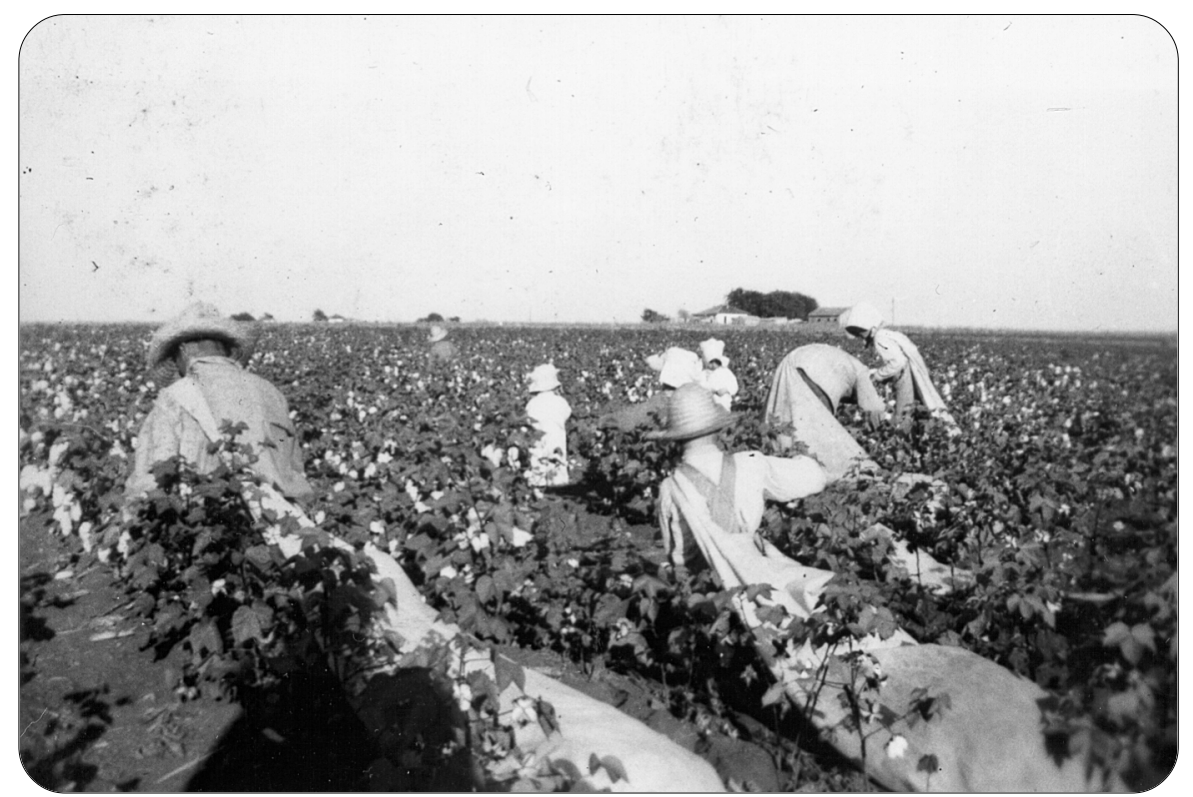

Figure 9d. Picking cotton near Granger, Texas. (ITC-UTSA, No. 98-158) a bale of cotton, you put it in the wagon, you bring it to the gin, they'll gin it for you, they'll tell you how much it brought you, you take that check to the landlord, you get half of it. When you're farming like he was, where he [the landlord] furnishes everything, he gets half of it. You go out there and harvest your corn, you count, one row for you and one for him. That's all it is, you don't go by the load. The way my daddy and I used to do it, we'd leave five rows there, that's for him, and I take these other five. See, if those five rows, adjoining your five, if they don't produce as much, if they don't produce more, you don't do anything about it. It's one row for you and one for him.”

When T. C. Osborn passed away, his daughter Mary took over. "Mary, she was living with her daddy and her mother. And when he died, Mary took over the farm, and my daddy continued working for her just like he did for Mr. Osborn. There was no change. He'd go to her, just like he did with her daddy. Like I was telling you, when you got to harvesting your cotton and you take that to the landlord - see you have to come up with quite a few bales before you can get anything out of it, cause see, all during the year, the landlord, he's advancing you money. They had a deal, where depending on the size of the family, they'd give you so much per month. And on the first of the month you'd go up there and get your money. Of course money was different then, it was hard to get, but it went a long way. You see today, it's easy to get, but it don't go nowhere." Mr. Martínez later recalled that the amount of the allowance was about \$20 per month.

"No, you're not gonna get rich [sharecropping]. But you see that's all, the Mexican people, that's all they did. That's all they knew. No, that's all you did. You just get by. And you bought things - it was just on a handshake back then. So at the end of the year you pay the boss man and you pay anybody else you owe. My father he used to have an uncle that lived on a farm, down this street right here, where you come to the river. He would say, 'Well I don't have anything left, but I've got my doors open.' See what he's saying is that he paid everybody, so he can 
go back and start charging from them tomorrow if he wants to, because you see, his name was good. He made good on that money he owed. See that was the deal, 'When my crop comes in, I will pay you.' And they did. And my daddy would say that money left his hands sore. 'So much money went through my hands, that that's all I have left, sore hands' he said."

Even before Mary Osborn passed away in 1952, she had already started to get out of the farming business. "She rented the land to a man that used to own a dairy, right across the street, a fellow by the name of Long. And my daddy went to work for him. He [Mr. Long] made arrangements with Mary. When she

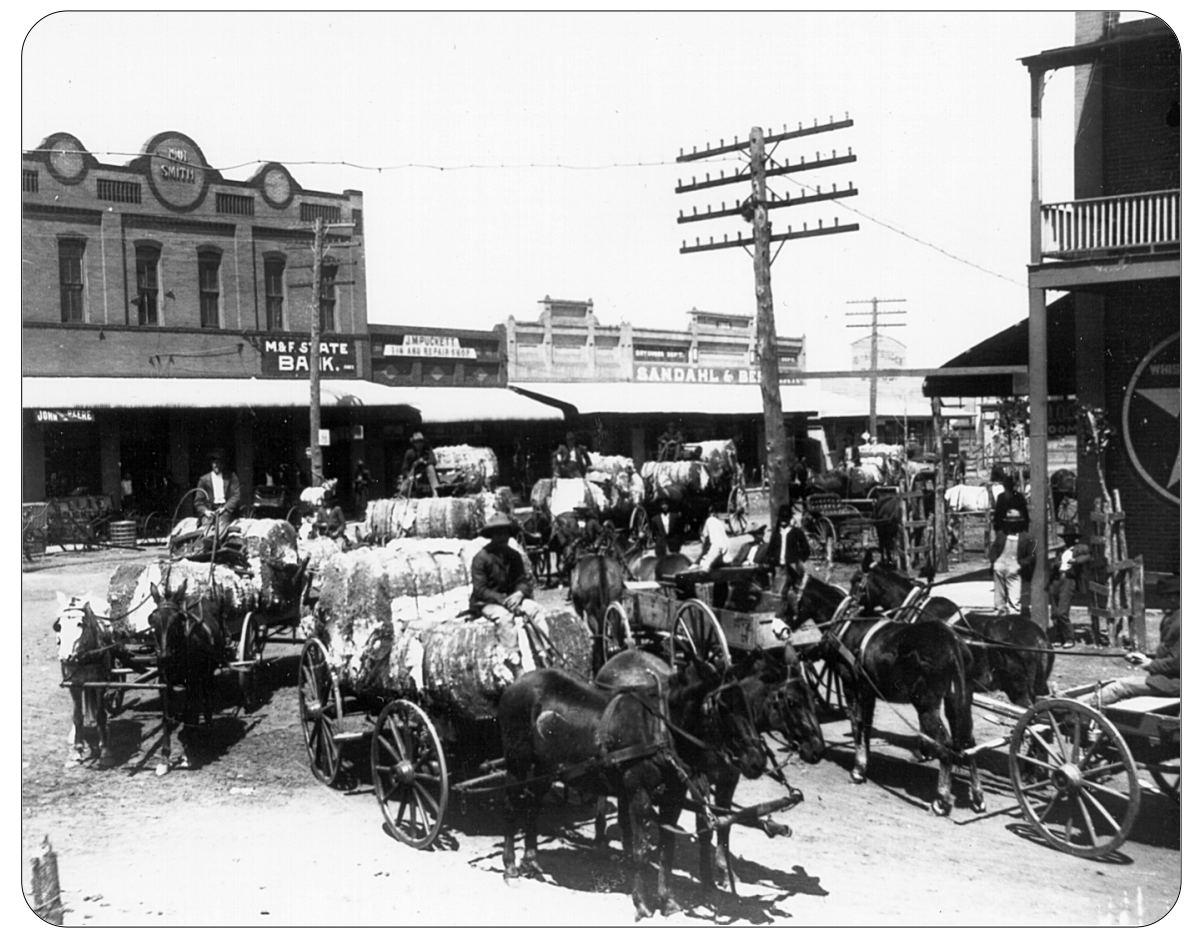

Figure 9e. Cotton wagons on their way to the cotton yard, Elgin, Texas. (ITC-UTSA, No. 96-1312) rented the place, she said [to Mr.

Long], 'I'll rent you the place, but this house has got nothing to do with it. Peter is going to live there for as long as he wants to.' He [my father] bought a lot over here in town, during the War, and he built a house on it. And he had been renting it. And he said, 'I just want to have a house so that when I get ready to move I'll have a place of my own to move into.' Cause you see, when she rented that place, that ranch to Mr. Long, she told him that daddy was going to live there rent free for as long as he lived. And then when she died, I don't know-Mr. Gore, who was married to a granddaughter of Mr. Osborn, and they took over the place. Mary Belle Turner Gore and her husband, Walter Gore, were local school teachers. Daddy moved into town while I was in Korea. I came back in fiftyfive, I think my daddy told me he moved [into town] in fifty-four." Mr. Martínez recalled that his uncles, John and Ysidro Domínguez, sharecropped on Earl Erhard's farm up until the late-1950s, and were the last to do so in the Bastrop area.

\section{Summary of Narratives}

It is apparent that all three tenant farm families shared fairly similar experiences. In all three cases, the families lived on and worked the farm in lieu of half the proceeds from the cotton harvest. All three received a monthly cash advance and/or were allowed credit, which was settled soon after the crops were harvested. In all three cases, the entire family provided the skilled and unskilled labor necessary to cultivate and harvest the crops.

It is interesting to note that by the mid-1950s, all three families had worked their way out of tenant farming and into more stable employment. What is also obvious is that all three-Barrón, García, and Martínez-were experienced and successful farmers. Another observation is that almost without exception, these farm families were Texas Mexicans (Tejanos). They were not recent arrivals, and they were certainly not refugees from the Mexican Revolution of ca. 1910-1917. 


\section{Artifactual Data}

The T. C. Osborn tenant farmhouse was located at the southern end of Bastrop, at the far south end of Pecan Street. The 1987 investigations by John Clark (TxDOT) focused on an area approximately $80 \mathrm{ft}$. wide, from east to west, by $160 \mathrm{ft}$. long, from north to south (12,800 square feet), with the house located along the south-end of the study area. Thirty-one units were excavated within the immediate vicinity of the structure, and to the north and south. Subsurface investigations also included the use of a gradall to blade two areas at the rear of the house (see Figure 5 in Results section).

This parcel of land and the tenant house was home to at least two families, but the extent and variety of cultural material suggests there may have been more. The structure was constructed ca. 1906 was continuously occupied until ca. 1950. The 1987 investigation included the documentation of what was left of the house, which met Historic American Building Survey (HABS) Level 3 guidelines. These 1987 field drawings were then used to describe and prepare a graphic representation of the structure (Figure 10). These data are followed by a section detailing an analysis of the recovered cultural material.

\section{Architecture The Board-and-Batten Home}

The early homes of Bastrop were constructed with expediency, and featured local materials. The most common early homes were log cabins, constructed from the same trees that were felled in order to clear the land for farming (Moore 1977). Numerous examples of Bastrop's early architecture are extant and listed on the National Register of Historic Places (Texas Historic Site Atlas 2000). Included in this inventory of early homes is a less romanticized cottage, typified by its board-and-batten exterior siding.

Board-and-batten was a fairly popular mid-nineteenth century house type. This type of house is recognizable by its siding of wide boards and narrow battens. This siding was popularized in the 1830s and 1840s, during the Gothic Revival period. The vertical arrangement of the board-andbatten siding was perceived as being a more natural way of using wood, given that trees grow vertically. By about 1900 its continued use was mostly limited to the drier Southwest, because the narrow battens warped and curled away from the walls in wetter northern climates (Glencoe Mill and Mill Village Historic District 2001).
As early as 1850, Bastrop County had five sawmills, which increased to nine by 1860 . These nine sawmills were producing close to four and one-half million linear feet of plank, and over one and one-half million roofing shingles per year (USDCa 1850). Wood shingle samples were recovered from the site, and these are $4 \frac{1}{4}$ in. wide by $16^{1 / 4}$ in. long. The shingles were $1 / 4 \mathrm{in}$. thick and the exposed end tapered to about $1 / 8$ inch.

A review of the Bastrop properties surveyed in the mid1970s and listed in the Historic Site Atlas of the Texas Historical Commission revealed no less than eight board-and-batten homes constructed between ca. 1850-90. Based on the available photos, there are two that resemble the T. C. Osborn share-tenant house in form and scale. One was at 1805 Pecan Street and the other at 1316 Farm Street, and both were constructed ca. 1870 (Texas Historic Site Atlas 2000). A recent pedestrian search for both properties proved unproductive.

Included in the above referenced inventory is a "Late Victorian Farm House" at the end of Pecan Street, with a date of construction of ca. 1880 (Texas Historic Site Atlas 2000). This " $T$ " plan board-and-batten farm house is directly across the street from the Osborn tenant house. (The house can be seen in the background of Figure 18, in the Summary section.) According to Louise García, Emma Rockwell, and Pete Martínez, Jr. (personal communications 2000), this house was home to "Brother Bell" and his family in the 1930s. Paul C. Bell (1886-1952) was the minister of the Mexican Baptist Church in Bastrop between 1914 and 1919, and pastor between 1923 and 1935. During this latter period, he served simultaneously as pastor of the Bastrop Baptist Church between 1925 and 1928. He left for two years, and then returned to serve as pastor between 1937 and 1941. Bell is also credited with establishing an elementary school for Mexican children in 1926, which continued in operation until May 1941 (Handbook of Texas Online 2000). The Mexican Baptist Church, and former site of the Mexican Baptist School, is located a few blocks northwest of the Osborn tenant house.

\section{T. C. Osborn Tenant Farm House}

According to the Osborn family, the board-and-batten home was constructed ca. 1906 by T. C. Osborn for the use of share-tenant families (Robinson 1989). Based on the archival research and oral histories, we now know that the house 


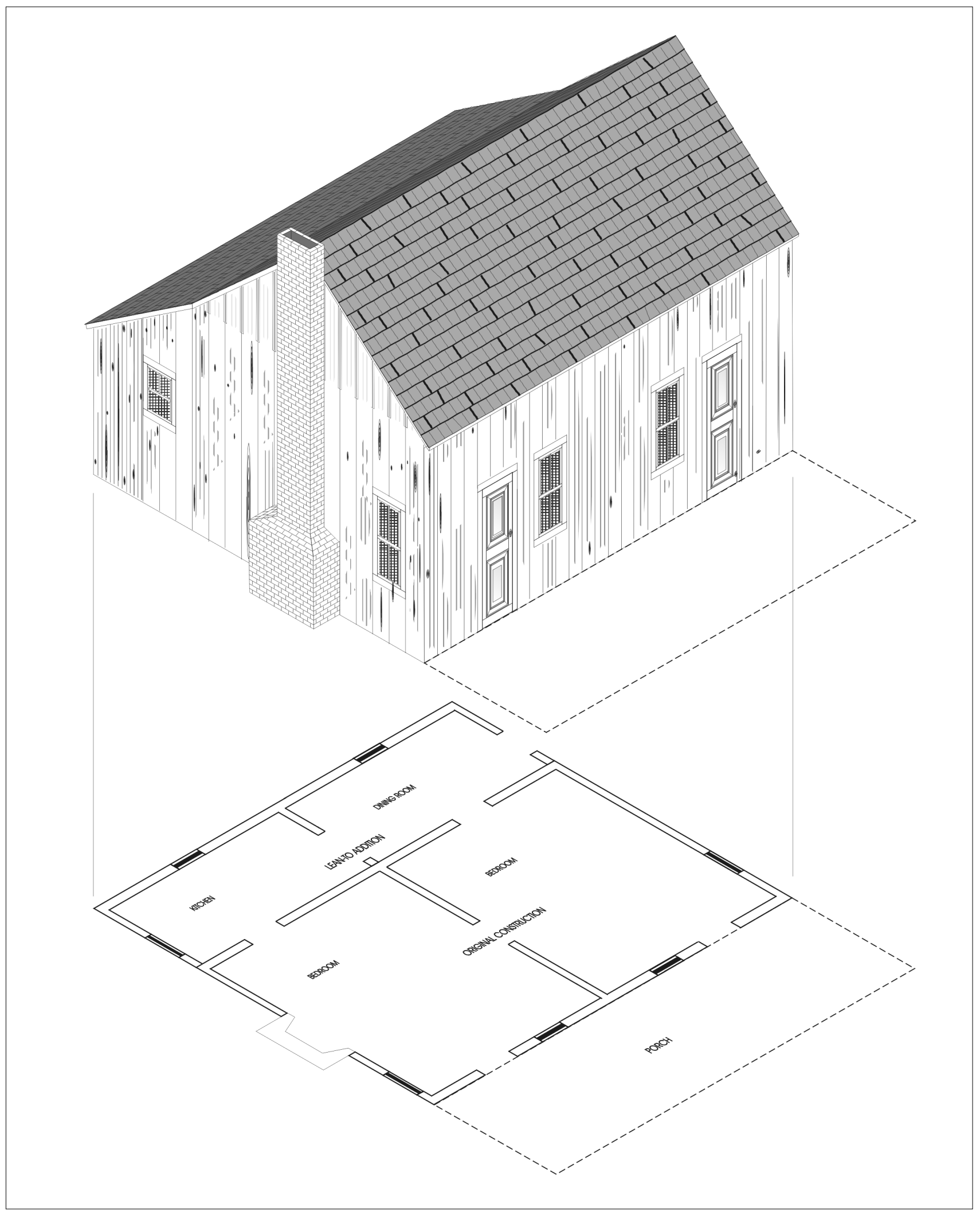

Figure 10. Isometric view of a reconstruction of the T. C. Osborn tenant house. 
was home to the Livorio González family (ca. 1906-25) and the David García family (1932-41). Given the artifactual evidence, we are certain that the house was continuously occupied during the first-half of the twentieth century, but were unable to find out who the other families were.

The Osborn farm and house were located outside the Bastrop City limits (see Figure 3). The share-tenant house was a one-story, two-room, side-gabled, with a two-room, lean-to addition at the rear. The house featured a gable-end chimney along the west elevation and a wood shingle roof. Although the house also featured a front porch, this was no longer extant in February 1987.

According to Emma Rockwell (personal communication 2000), the front facade did have two entrances as well as two windows. The front doors led into separate bedrooms (living areas), and the rooms at the rear, lean-to portion served as a kitchen and dining room (Figure 10). The main structure of the house was $14 \frac{1}{2} \mathrm{ft}$. wide by $28^{1 / 2} \mathrm{ft}$. long. The lean-to addition ran the full length of the rear of the house $(281 / 2 \mathrm{ft}$.) and was $7 \mathrm{ft}$. wide. The front of the house was oriented slightly to the southeast, and faced onto Pecan Street. The house lacked any sort of utilities, either plumbing or electrical.

\section{House Plan and Elevations}

The typical board-and-batten house begins with the construction of a one to two room structure on a pier and beam foundation. The framework, known as balloon framing, was primarily of $2 \times 4$ in. studs, which were then enclosed with $1 \times 12$ in. boards nailed vertically to form the walls. To allow for expansion, the boards were spaced $1 / 2$ in. apart, and the spaces were then covered over with $1 \times 3$ in., or $1 \times$ 4 in., narrow boards (batten). These small houses had wooden floors and gabled roofs of wooden shingles, which were often later replaced with galvanized metal roofs. As the family grew and financial circumstances permitted, rooms were added to the back of the house and perhaps a porch to the front and to the rear.

The Osborn tenant house is a typical model of a type of residential structure that was popularized in the mid-1800s and carried over well into the twentieth century. The house features are especially characteristic of post-railroad folk housing construction (McAlester and McAlester 1986). This style of folk housing is often referred to as Cumberland architectural type, and consists of two front rooms, typically of equal size, with two front doors. As in this example, rooms are generally added into the original design as a rear addition (Raab 1982). The practicality and low-cost of this type of house made it a favorite in agricultural settings as housing for transient farm workers.

Figure 6 serves to illustrate that the house was in a serious state of deterioration in early 1987. Based on this and a series of other photos, we know that by this late date, the chimney had already collapsed and the missing bricks most likely had been carted off to be recycled elsewhere. The east half of the house had collapsed and the material remained where it had fallen. The TxDOT archaeologists had to remove this debris in order to proceed with their excavations. Most of the doors were missing and the windowpanes had all been broken. The front facade, south elevation, of the west half of the house had been removed, probably to allow for easy access and use as a hay barn.

Based on the oral histories, we know that this broken-down house, as modest as it may have been, was home to no less than two families who were anything but transient. The following illustrations serve to depict how the house would have looked during its prime. By utilizing three distinct data sources, we were able to produce a series of illustrations that included a plan view, four elevations, and an isometric view of the house (see Figures 10 through 12). These images are from a collection of several black and white photos of the structure taken by the TxDOT crew in February 1987. These photos were then cross-referenced against a second source, the architectural field sketches and details executed by Tom Eisenhower of TxDOT. The accuracy of the draft illustrations was then confirmed by Emma Rockwell, former resident (personal communication). Based on Emma Rockwell's recollections, we were also able to recreate the footprint of the front porch.

\section{Artifact Analysis}

Well over 9,000 individual artifacts were collected during this investigation. These artifacts were recovered from 32 units: 13 units were excavated within the immediate vicinity of the house and an additional six units were located and excavated to the south and southeast of the house. Another 13 units were located and excavated to the rear, or north, of the house. Two additional areas were investigated, about $60 \mathrm{ft}$. north of the house, in an effort to locate the privy and/ or other outbuildings. According to Mrs. Rockwell (cited 
previously), the privy was located about $100 \mathrm{ft}$. to the north of the house and towards the creek, which means that the field crew was about $40 \mathrm{ft}$. short of the mark.

With the exception of one triangular-shaped unit, the rest of the units were $5 \mathrm{ft}$. by $5 \mathrm{ft}$. (1.5 $\mathrm{m} \times 1.5 \mathrm{~m}$ ) square and all were excavated in a single level of about 12 in. $(30.5 \mathrm{~cm})$ below surface. Given this mode of recovery, it was impossible to stratigraphically isolate the artifacts. These conditions also made it impossible to determine if the artifacts were associated with sheet refuse or recovered from an intact matrix. Nevertheless, we were able to formulate a minimal amount of discussion regarding the spatial distribution of the artifacts.

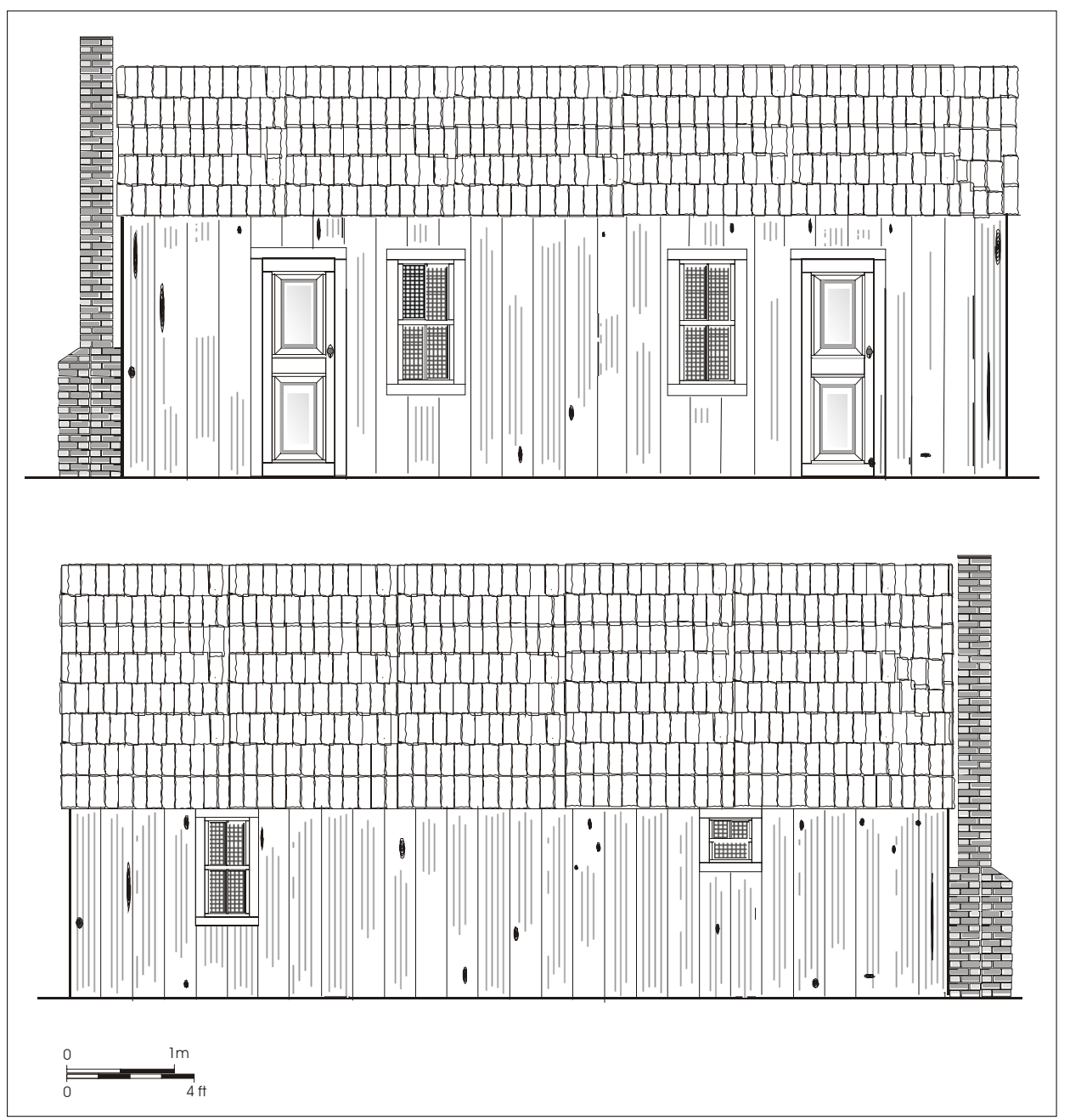

Figure 11. South elevation, front of house, (top) and north elevation, rear of house, (bottom) of T. C. Osborn house.

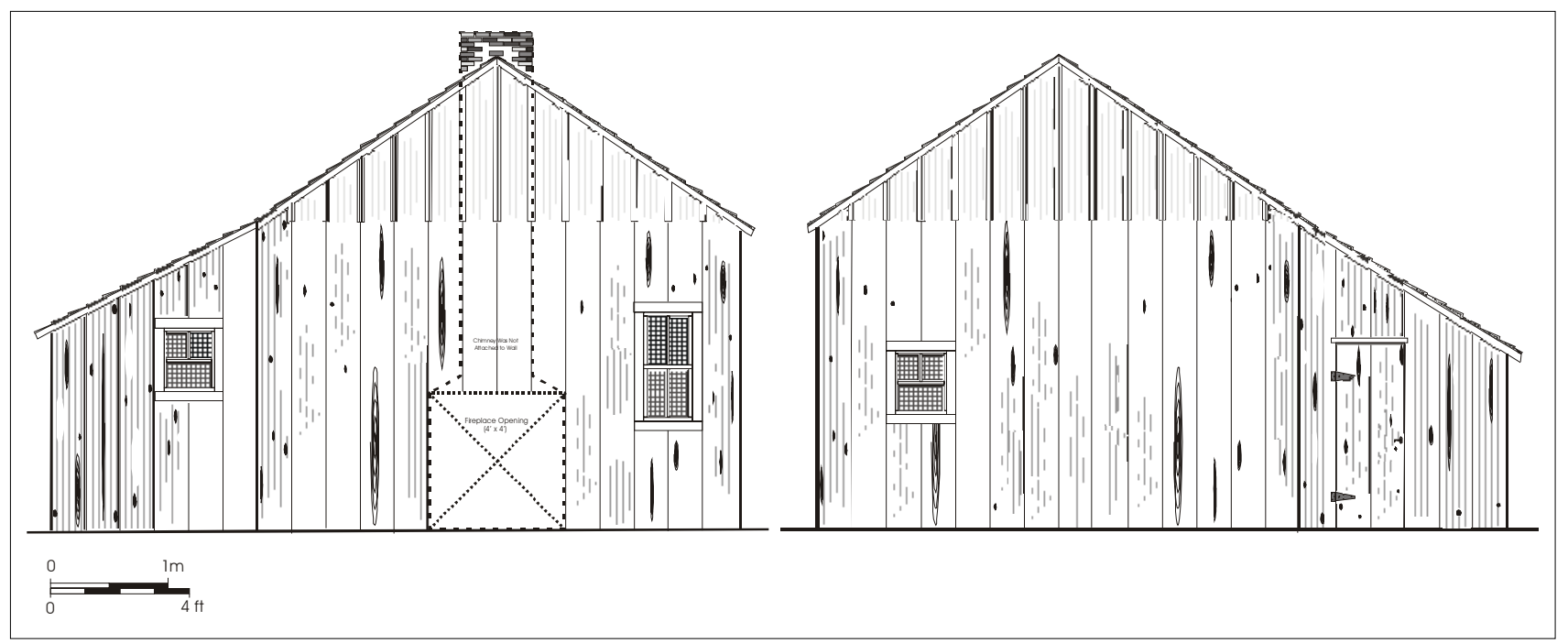

Figure 12. West (left) and east (right) elevations of the T. C. Osborn house. 
Table 6. Summary of Recovered Material

\begin{tabular}{|c|c|c|c|c|c|c|c|c|c|c|c|c|}
\hline & $\begin{array}{c}\text { Chipped } \\
\text { Stone }\end{array}$ & $\begin{array}{c}\text { Metal } \\
\text { Objects }\end{array}$ & Misc. & $\begin{array}{c}\text { Shell \& } \\
\text { Snail }\end{array}$ & Activity & $\begin{array}{c}\text { Clothing \& } \\
\text { Personal } \\
\end{array}$ & $\begin{array}{c}\text { Arms \& } \\
\text { Ammunition }\end{array}$ & $\begin{array}{l}\text { Barn \& } \\
\text { Wrkshp } \\
\end{array}$ & $\begin{array}{l}\text { Kitchen \& } \\
\text { Household }\end{array}$ & Ceramics & Construction & Total \\
\hline Count & 96 & 425 & 141 & 107 & 40 & 128 & 11 & 411 & 3237 & 1413 & 3624 & 9633 \\
\hline$\%$ & 1.0 & 4.4 & 1.5 & 1.1 & 0.4 & 1.3 & 0.1 & 4.3 & 33.6 & 14.7 & 37.6 & 100.0 \\
\hline
\end{tabular}

An inventory of the recovered material is presented in Appendix A, and a synopsis of this is presented in Table 6. Close to thirty-eight percent of the recovered material was construction-related, such as assorted hinges, nails, wood screws, and window glass. The next highest percentage of collected material was associated with kitchen and household items (34 percent), such as bottle and jar caps, bottle and vessel glass, and can fragments. The third highest category of material collected was ceramics (15 percent), including a variety of whiteware, porcelain, and stoneware sherds.

The recovered cultural material strongly suggests a post1900 occupation that carried over well into the 1950s. This is especially obvious when considering that only five percent of the total bottle glass recovered was manganese bleached (pre-1915 origin). In contrast, the occurrence of selenium bleached bottle glass (post-1915 origin) was five times greater. Based on glass vessel sherds, there was greater evidence for post-1900 occupation of the site, with well over half of the sample being represented by selenium-bleached sherds. The largest percentage ceramic type recovered from this site was undecorated whiteware (67 percent), which was a fairly common house ware by 1915 . Another strong indicator of a post-1900 occupation was the amount of cut nails vs. wire nails. A total of 38 percent of the recovered nails were cut nails, while 62 percent were wire nails. Regardless of type, a large percentage of the recovered nails were $6 \mathrm{~d}$, $7 \mathrm{~d}$, and $8 \mathrm{~d}$ sizes, which are commonly used on roof and wall components (Brown et al. 1998).

A summary of the analysis of the cultural material is presented below. We had proposed to undertake a comparative analysis of a select type of cultural material, but this idea was abandoned since it seemed redundant given the extensive oral narratives. We also attempted to identify artifact densities, or concentrations, throughout the site based on artifact types (e.g., Construction, Activity, etc.). After comparing the percentage of artifacts between units, we found that Clothing/Personal was the only category that showed higher/lower concentrations between units. The highest concentrations of Clothing/Personal items occurred beneath the east end bedroom (13 percent) and along the exterior of the west end bedroom ( 8 percent). Another concentration
(12 percent) was recovered from a unit located about $50 \mathrm{ft}$. from the rear of the house. These three units also accounted for the recovery of 30 percent of the buttons. A series of graphic representations of select artifacts is presented in the discussion. This section is concluded with a detailed analysis and discussion of the recovered faunal remains.

\section{Chipped Stone}

A total of 96 chipped stone fragments were recovered. Of these, 81 were fire-cracked rock, and 15 were classified as flakes. Most of this material was recovered from units located between Feature 1 and the well, approximately $40 \mathrm{ft}$. south of Gills Branch Creek. An additional 43 pieces were determined to have been mislabeled, and were not chipped stone. The presence of chipped stone is not at all surprising given the site's close proximity to Gills Branch Creek and the Colorado River.

\section{Metal Objects}

Over 400 assorted metal fragments were recovered, and most of these were unidentifiable. This collection consists of 4.8 pounds $(2.2 \mathrm{~kg})$ of mostly unidentified metal objects, such as bits and pieces of brass, copper, lead, iron, and sheet metal. It would seem likely that most of these fragments at one time related to barn and workshop items, as well as construction-related hardware.

\section{Miscellaneous}

This category included an odd assortment of mostly nondiagnostic artifacts $(\mathrm{n}=141)$. Items recovered included an aluminum fragment, bits and pieces of cardboard and paper, coal fragments, egg shells, peach seeds, and unidentified fragments of fabric, plastic, wood, and rubber. Included in this category is a relatively small collection of mussel shell and snail. A total of $8.3 \mathrm{oz}$. (258.2 g) of mussel shell and $0.15 \mathrm{oz}$. $(4.67 \mathrm{~g})$ of snail shell were recovered.

\section{Activity}

A total of 40 items were included in this category. Over half of these $(n=22)$, were school or education-related, such as slate fragments, slate marker fragments, and pencil fragments. Over half of the writing material was recovered in 
close proximity to the two bedrooms and front porch. The slate markers $(n=3)$ had initially been mislabeled as simply slate fragments. This slate material is interesting as it definitely related to ca. 1910 school material. An advertisement by the Peoples Cash Grocery states that they "have bought a large stock of Tablets...Slates..." (Bastrop Advertiser, October 8,1910$)$. The remaining 18 items related to toys and game pieces, with nine of these being ca. 1930 marbles (Zapata 1997). The items shown in Figure 13 are a representative sample of activity-related items which all date to ca. 1920-40 (Meissner 1997a).

\section{Clothing/Personal}

A total of 128 personal items were recovered. Within this category, the highest number of items was buttons $(n=83)$, with 42 of these being shell buttons. In terms of density, most of these artifacts were recovered from within and immediately outside of the house (Unit N505/E510, n=16 and Unit N520/E515, n=14). An additional concentration was recovered from a unit located about $40 \mathrm{ft}$. behind the house (Unit N580/E500, n=17). A sample of personal items, beads, and earrings are also shown in Figure 13. Numerous clothing-related items were recovered, and include an assortment of buttons (Figure 14). The celluloid and glass buttons all date to within the first-half of the twentieth century, while the plastic buttons probably date to ca. 1945 (Meissner 1997b). Also recovered and shown in Figure 15 were some metal buttons and fasteners commonly used on work pants, such as those found on overalls. They were fairly common and are still in use today.

\section{Arms and Ammunition}

A total of 11 cartridges were recovered. Five were .22 caliber, one .25 caliber, one .32 caliber, one .45 caliber, and 3 shotgun shells. These specimens were found scattered across the project area, exhibiting no particular signs of concentration.

\section{Barn/Workshop}

The vast majority of these items consisted of metal strapping and wire fragments. One-half pound of strap fragments were recovered, as was one and one-half pounds of wire fragments. Among the recovered material were 13 small fragments of fairly common two-point barbed wire, as well as three size-D batteries and three battery core fragments. A total of 12 items relating to tools and 48 items relating to machinery parts were recovered, and included file fragments, nuts, and bolts.

\section{Kitchen/Household}

The recovered material within this category comprised the second highest percentage of the total material collected at this site. A number of complete bottle and jar caps were recovered, as well as can fragments and lamp glass. The largest amount of material recovered was bottle glass, 2,105 fragments $(10.9 \mathrm{lbs})$. Vessel glass (e.g., jars and possibly drinking glasses) comprised the next highest number, with a total of 584 fragments $(4.2 \mathrm{lbs})$. Figure 16 shows three of the bottles recovered. These date to between ca. 1930 and 1940 (Toulouse 1971).

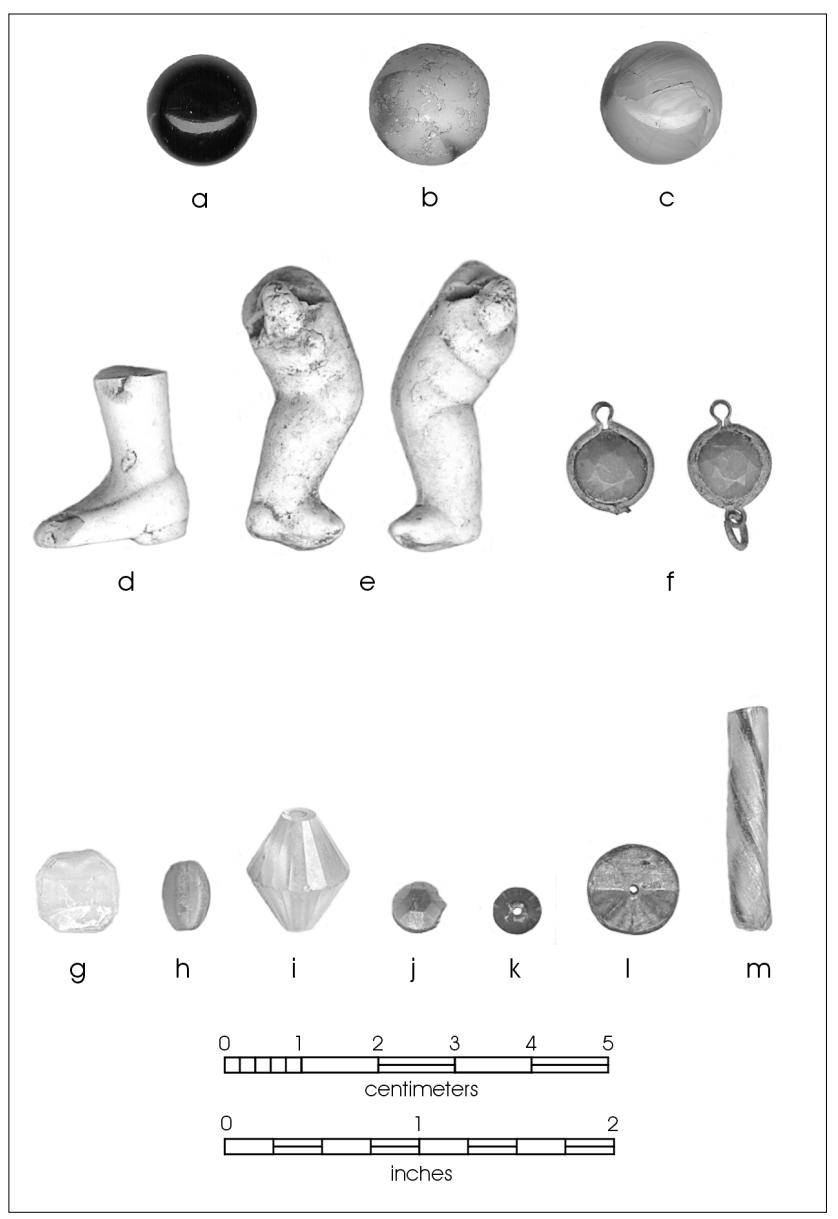

Figure 13. Samples of activity and personal items recovered from the T. C. Osborn site. a) black, "pee-wee" marble; b) opaque, green and white swirl marble; c) translucent, dark green and white, swirl marble; d) doll's lower leg, bisque; e) doll's leg, infant with raised toes (pair), bisque, with selfshank for joinery; f) earring pendants, plastic; g-m) assorted costume jewelry beads. 


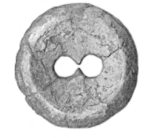

a

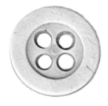

d

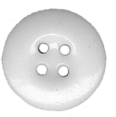

h

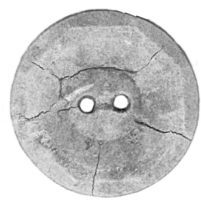

b
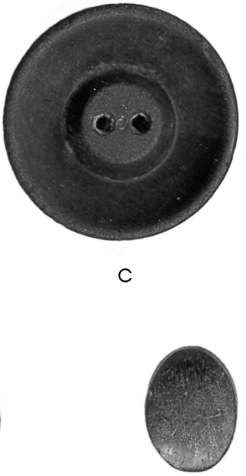

g

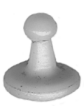

$\mathrm{m}$

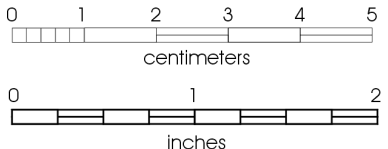

Figure 14. Samples of assorted buttons recovered from the T. C. Osborn site. a-c) celluloid buttons; d-g) plastic buttons; h-l) glass buttons; m) collar stud.

Five percent of the total bottle glass recovered was manganese bleached (pre-1915 origin), and 26 percent was selenium bleached (post-1915 origin). The occurrence of pre-1915 vessel glass (4 percent) was fairly similar to that of the bottle glass. There was, however, greater evidence for post-1915 vessel glass, with 55 percent of the recovered vessel glass represented by selenium bleached sherds.

\section{Ceramics}

The greatest number of ceramics were recovered from behind the house, with 64 percent of these from five distinct areas with a total of 100 or more sherds. Almost a third of the total number of ceramics were recovered from an area comprised of three lots, located between 40 and $90 \mathrm{ft}$. behind the house.

The earliest type of ceramics recovered from this site was tin-glazed - Guanajuato and Monterey, representing less than one percent of the total ( 0.8 percent). Considering the age and scarcity of these types (ca. mid-nineteenth century), they most likely represent heirloom pieces. There was a small percentage of stoneware (4 percent), mostly salt glazed, represented in the collection.

Considering the entire collection, the largest percentage (67 percent) was comprised of undecorated whiteware. This type of undecorated whiteware is fairly common in post-Civil War sites. The next highest grouping (11 percent) was comprised of an assortment of whitewares (e.g., banded slip, decal, decorated, edge decorated, hand-painted, plain color, spatter, and transfer).

\section{Construction}

Over one-third of the recovered material was construction-related $(n=3,624)$, and included an assortment of door and gate hinges, cut and wire nails, wood screws, and window glass. Of these items, the largest number recovered was window glass $(n=1,494)$. The recovered window glass ranged in thickness from $2 \mathrm{~mm}$ to $3 \mathrm{~mm}$, with one fragment being $6 \mathrm{~mm}$ thick. Of this sample 4.3 percent were $2 \mathrm{~mm}$ thick, 22.4 percent were 2.5 $\mathrm{mm}$ thick, and 14.7 percent were $3 \mathrm{~mm}$ thick.

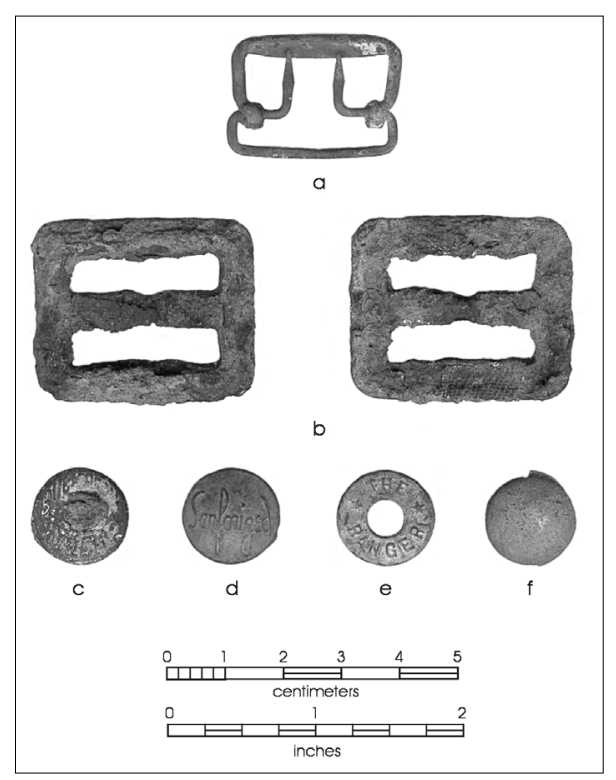

Figure 15. Samples of metal work clothing accessories. a) strap D-clasp; b) strap slides; c-f) assorted metal buttons and fasteners. 


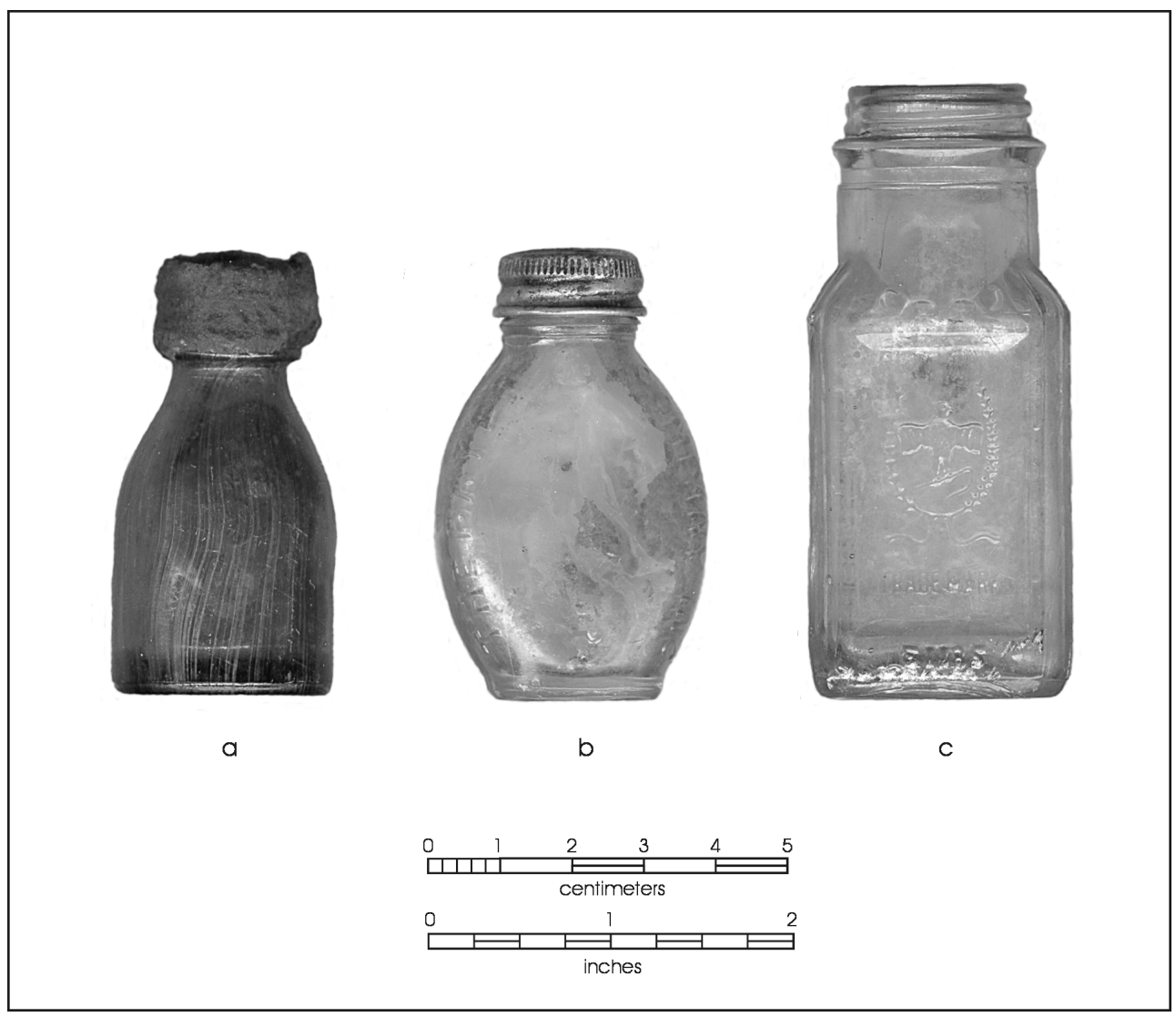

Figure 16. Samples of bottles recovered from the T. C. Osborn site. a) "Vicks Va-Tro-Nol 24" nose drops, cobalt blue, ca. 1935; b) "Bayer" aspirin bottle, ca. 1930; c) "Gebhardt Eagle" chili powder bottle, ca. 1940 .

A total of 708 cut nails were recovered. Thirty-two percent of the recovered cut nails were $6 \mathrm{~d}$, commonly used on nailers (shingle or shake roof systems). The rest of the cut nails ranged in size from $4 \mathrm{~d}$ to $40 \mathrm{~d}$, with no obvious concentration of any one type. The largest number of nails recovered from this site was wire $(\mathrm{n}=1,145)$. Thirty-one percent of the wire nails were $7 \mathrm{~d}$ and $8 \mathrm{~d}-$ commonly used for flooring and siding. The rest of the recovered nails ranged in size from $2 \mathrm{~d}$ to $60 \mathrm{~d}$, with no obvious concentration of any one type.

The recovered material also included some bolts and nuts, mortar fragments, brick fragments, and complete bricks. Also included in the excavated sample were two cold chisels, an L-brace, three ceramic door knob fragments, 15 assorted hinges (door, gate, and cabinet), three electrical insulator fragments, five sections of galvanized pipe, about 33 grams of wood fragments, and six flat washers.

\section{Summary}

The most abundant materials recovered at this site relate directly to the board-and-batten home. This is not at all surprising, given that when the site was investigated in 1987 the house had already been abandoned for nearly 30 years. As demonstrated previously in Figure 6, the structure's state of deterioration was quite advanced, with an enormous number of architectural elements scattered about. Although an abundance of flat glass $(n=1,494)$ was recovered, we decided not to proceed with an analysis of this glass, since we already had excellent information regarding the 50-year history of the structure. With the exception of the chipped stone artifacts, the vast majority of the recovered material was of ca. 1900-1950 origin, and none appeared to be of post-1950 origin. In an effort to glean more information from the recovered cultural material, the faunal remains were intensively studied, and the findings are presented in this report. 


\section{Vertebrate Faunal Remains}

\section{Methods}

A total of 620 vertebrate faunal remains, weighing 1,140.23 $\mathrm{g}$, was recovered during the project. The bone was identified to the most specific taxon possible using the comparative collection at CAR, as well as several reference texts (Balkwill and Cumbaa 1992; Cohen and Serjeantson 1996; Gilbert 1990; Hildebrand 1955; Hillson 1986; Olsen 1960, 1964, 1968; Sobolik and Steele 1996). Identifications were conservative, i.e., bone that appeared to be cow-sized was not identified as Bos taurus unless it could be differentiated from Bison and Equus species. One exception to this is that all saw-cut bone of cow size was tentatively identified at Bos taurus, under the assumption that bison and horse would not be butchered in this fashion during the time the farm was occupied. All bone was weighed, and evidence of exposure to heat was noted on all bone. Element, portion of element, side, evidence of immaturity, butcher marks, and pathologies were noted on bone identified to the order taxonomic level. When bone could be identified only to class (e.g., mammal, bird, etc.) an estimate of the size of the animal was made when possible. After the analysis, the bone was bagged by unit and level. Bone identified to at least the order taxonomic level was bagged separately and included in the unit-level bags.

Two measures of relative abundance were used to estimate the importance of all species to the meat diet as represented by this collection: Number of Identified Specimens (NISP) and bone weight. NISP is the count of specimens that have been identified to at least the genus taxonomic level. Its use as a measure of relative abundance is problematic (Grayson 1984:20-24; Reitz and Wing 1999:191-192). As Reitz and Wing (1999:192) have remarked: "By using [NISP] as a measure of abundance, the analyst assumes cultural and noncultural fragmentation is uniform, recovery rates are constant for each taxon, and all taxa have an equal opportunity to be counted." NISP cannot differentiate between 11 fragments from 11 different cows and 11 fragments of a single cow bone. Reliance on NISP alone will distort the estimate of relative abundance in favor of small animals and animals with parts that are more readily identifiable in fragmentary form.

The Minimum Number of Individuals (MNI) is often used to correct some of the problems with NISP (Reitz and Wing 1999:194,197-198). MNI is the number of individuals necessary to account for the bone present. MNI is of very limited usefulness in collections that are the result of a market economy, i.e., when some or much of the meat was purchased in table-ready cuts from butchers. In addition, in a small collection such as this, with bone collected from widely spaced units, MNI becomes more a count of presence/absence in a unit, and is of little value.

Bone weight can also, with caution, be used as a measure of relative abundance. Bone weight is, in general, a better indicator of relative dietary importance (as opposed to relative abundance) than NISP, but this measure must not be used exclusively. In general, larger bones carry more meat, but the relationship is not linear (Reitz and Wing 1999:222231), varies among different taxa, and there is considerable variation from one part of the animal to another (e.g., lower legs of cattle are dense, heavy bones but carry relatively little meat compared to other bones of the body). The use of bone weight as an assessment of dietary importance also suffers from the necessary assumption that all taphonomic factors that affect bone weight (such as leaching, mineralization, or encrustation) have affected all bone in the collection uniformly. Bone weight tends to emphasize the importance of larger, heavier animals, and because of this, tends to counter-balance the tendency of NISP to emphasize smaller animals.

Each analytic method discussed above is subject to a number of biases (Reitz and Wing 1999:200). The degree to which any of these biases has affected the collection cannot usually be assessed. Used together, however, NISP and bone weight can provide a better picture of the relative importance of each species to the diet than either can provide when used alone.

\section{Analysis}

A list of identified taxa is shown in Table 7, with counts and weights. A complete, provenienced list of all data recovered from the bone is in Appendix B. The bone was generally in good condition, with little evidence of damage from atmospheric or chemical weathering, however 79.2 percent of the bone could be identified only as mammalian. Eightyseven bones (14 percent) could be identified to the genus taxonomic level.

\section{Taxa Identified}

A total of 14 genera was identified. Opossum (Didelphis virginiana) is the most common identified bone, constituting 
The T. C. Osborn Tenant Farm, 4IBP314

Table 7. Taxon List

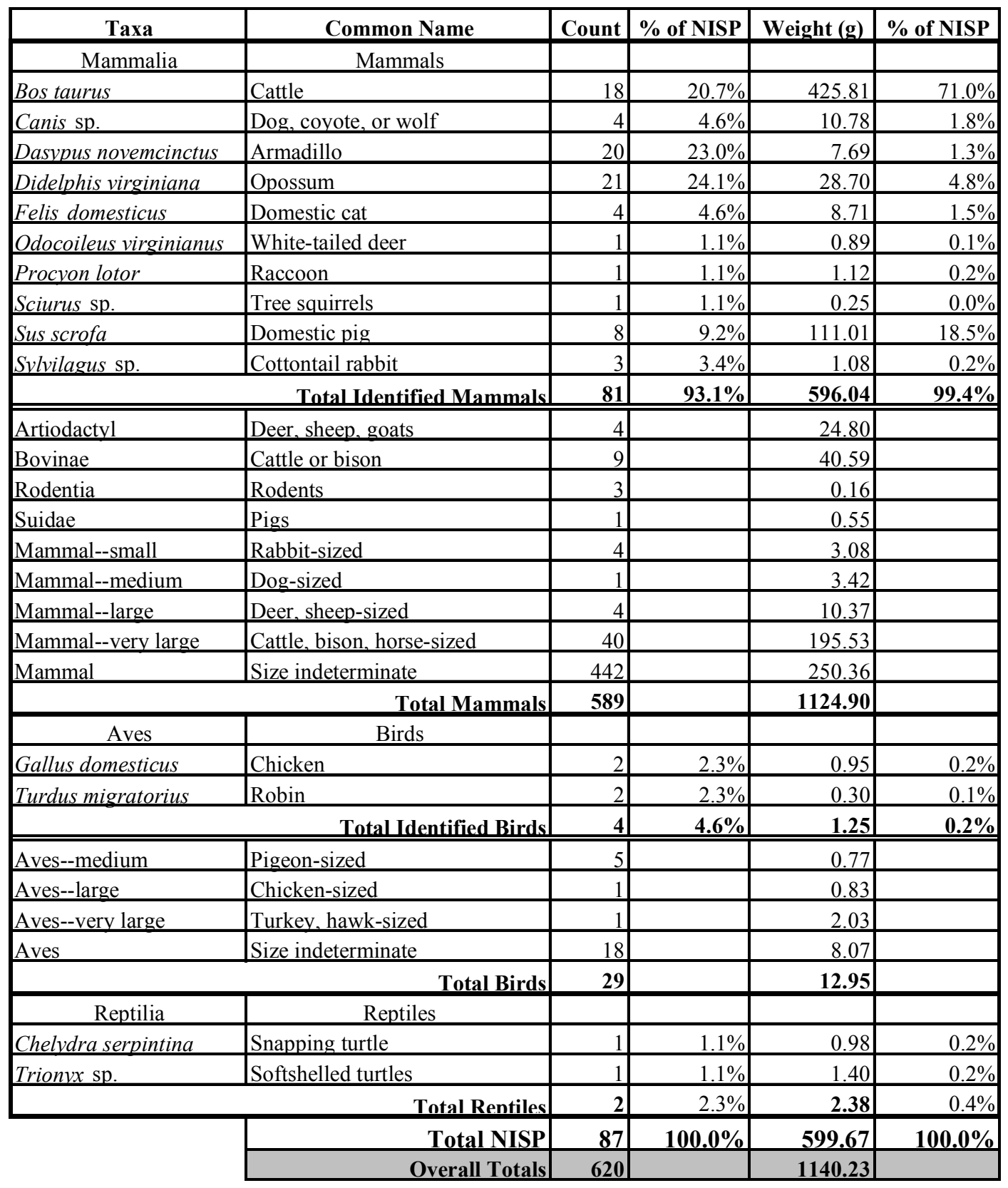

24.1 percent of the total, and armadillo (Dasypus novemcinctus) the next most common taxa (Table 7), with 23 percent of the NISP. In fact, wild mammals make up 54 percent $(n=47)$ of the total NISP. Cattle are the third most common, with 20.7 percent of the NISP. Of domestic animals commonly used for food, only cattle (Bos taurus) and pigs (Sus scrofa) are represented in this collection. No fish bone, and only two turtle bones, were identified, totaling 2.3 percent of the NISP.
As discussed in the Methods section, however, NISP gives a false impression of the importance of species with smaller body weight. Table 8 , which shows the percentage of total NISP weight for each of the categories listed above, indicates that the meat diet represented by this collection is dominated by domestic food animals, which together constitute 89.5 percent of the NISP bone weight. Although wild mammals are well represented in the NISP, they are only a small percentage of the NISP bone weight (Table 8). 
Table 8. Percent of Total NISP Bone Weight for Selected Taxa

\begin{tabular}{|l|c|}
\hline Taxa Category & \% of Total NISP Weight \\
\hline Cattle & $71.00 \%$ \\
\hline Pigs & $18.50 \%$ \\
\hline Wild mammals & $6.60 \%$ \\
\hline Chicken & $0.20 \%$ \\
\hline Turtles & $0.40 \%$ \\
\hline
\end{tabular}

\section{Butchering}

Butchering marks were recorded only on bone that was identified to at least the order taxonomic level, with one exception. All saw marks on bones for which the size of the animal could be estimated were recorded, since most sawed bones were too small to identify to the order taxonomic level. As mentioned in the methods section, however, sawed bone that was cow-sized was assumed to be cow.

Table 9 lists the butcher mark types and the number of bones displaying these marks by taxon. Fifteen bones in the collection (2.4 percent of the total) showed evidence of being sawed. Of these, the type of saw could not be identified on three bones. Two other bones had been sawed with a machine saw, indicating they had been butchered in the twentieth century. The remainder of the sawed bone was cut with hand saws, a nineteenth-century butchering practice.

\section{Meat Cuts Represented}

Meat cuts represented by the identified beef bone is listed in Table 10. Nineteenth-century butchering patterns were similar to those used today (Clonts 1983:350), although the relative value of each cut has shifted somewhat over time (Schulz and Gust 1983:48). The ranking of each cut presented in Table 10 is based on records from the latter half of the nineteenth century, as presented in Schulz and Gust (1983:48). The majority of the bone is from moderate to less expensive cuts. In fact one-third of the bone is from the least expensive cuts, the hind and foreshank.

\section{Evidence of Heat Alteration}

Evidence of exposure to heat can indicate whether bone was routinely thrown into the fire as a disposal method. Normally, cooking of meat, even over an open fire, will only smoke-stain or char the bone. The duration and intensity of heating necessary to calcine bone is considerable. It is unlikely to occur during routine cooking (Lyman 1994:388-389). In this collection, 32.5 percent $(n=183)$ of the bone showed evidence of heat alteration (Table 11). Of these, 80.3 percent $(n=147)$ were partially calcined or fully calcined. This strongly suggests that bone was burned as a disposal method, probably with other trash.

\section{Discussion}

This collection is very small, and the small number of identified bone severely limits the inferences that can be drawn from this analysis. However, a few observations can be made and conclusions can be drawn while keeping the limits of a small sample size in mind.

Almost all of the identified beef bone was sawed, in cuts that have been standard, at least for Anglo-American butchers, since the middle of the nineteenth century (Schulz and Gust 1983:48). No beef head, foot, or tail elements were recovered. This strongly indicates that the beef represented by this bone was purchased from professional butchers, in retail cuts.

Table 9. Butchering Mark Types and Counts

\begin{tabular}{|l|c|l|}
\hline \multicolumn{1}{|c|}{ Type } & Count & \multicolumn{1}{c|}{ Notes } \\
\hline Cut & 1 & Only seen on humerus of a snapping turtle \\
\hline Chop & 3 & $\begin{array}{l}\text { Cow atlas chopped in half; distal tips of medial maleolus of cow tibia chopped off } \\
\text { (bone had been sawed just proximal of the epiphysis); pig cranium also chopped. }\end{array}$ \\
\hline Hand sawed & 10 & Includes 2 radii, 3 femora, 3 tibia, and 2 innominates of cattle \\
\hline Machine sawed & 2 & Includes 1 femur and 1 innominate of cattle. \\
\hline Saw (Indeterminate) & 3 & Includes 1 rib, 1 ulna, and 1 innominate of cattle \\
\hline Impact scar & 1 & Located just above semi-lunar notch of cow ulna \\
\hline
\end{tabular}


Table 10. Meat Cuts Represented in the Collection, with an Ordinal Scale of Value (Based on Schulz and Gust 1983)

\begin{tabular}{|l|c|l|c|}
\hline \multicolumn{1}{|c|}{ Element } & Count & Cut Represented & 19th Century Ranking \\
\hline Femur (distal and medial) & 3 & Round steak & 3 \\
\hline Ischium & 4 & Rump & 4 \\
\hline Proximal rib & 1 & Chuck & 5 \\
\hline Distal 1st rib & 1 & Cross rib & 6 \\
\hline Atlas & 1 & Neck & 8 \\
\hline Radius & 2 & Foreshank & 9 \\
\hline Tibia & 3 & Hindshank & 9 \\
\hline
\end{tabular}

Most of the identified pig bones (Sus scrofa) were fragments of head and teeth. One pig ulna had been sawed just distal of the semi-lunar notch, but also had an impact scar in the olecranon. There are too few pig bones identified to be sure, but it is possible that pigs may have been grown and butchered on site.

Most of the animals identified in this collection were wild animals, including deer (a single tooth fragment), squirrel (a single ulna), opossum, and armadillo. Any of these may have been hunted for food, but except for the deer, any of them may have been killed or found dead, and simply disposed of in the trash. There are, however, cut marks on one of the turtle bones, suggesting that the meat was removed. Unfortunately, the sample is too small to allow speculation on how much the meat diet on the farm was supplemented by hunting.

\section{Summary}

This collection of only 620 bones, of which only 87 were identifiable, is too small to allow more than a few suggestions about diet, butchering, and participation in a market economy. The bones identified suggest that beef was purchased from grocery or butcher stores, while the pig may have been grown and butchered at home. Mammals commonly hunted for food are present and may have been part of the diet. There is evidence that bones were commonly disposed of by burning, probably with other trash.

Due to the small sample size, this collection is only able to hint at the nature of the meat diet on the farm, and how that meat was acquired.

Table 11. Counts of Heat-Altered Bone

\begin{tabular}{|c|c|}
\hline Heat Alteration & Count \\
\hline Smoke stained & 3 \\
\hline Charred & 33 \\
\hline Partially calcined & 74 \\
\hline Calcined & 73 \\
\hline Total & 183 \\
\hline
\end{tabular}




\section{Summary and Conclusions}

In addition to placing the Osborn Farm site in historical context, this study was also designed to respond to two basic issues: 1) Mexican immigration patterns, and 2) social and economic relationships within an early twentieth century rural community. The personal narratives furnished by former Osborn Farm sharecroppers were critical to achieving a synthesis of the data.

Based on the archival data and oral narratives, we now know that the T. C. Osborn site (41BP314) and the G. W. Jones site (41BP86) were linked through ownership and cotton farming. The sites, however, were found to consist of diverse historic-period components. The Jones site (41BP86) was continuously occupied between ca. 1840 and 1952, and can be regarded as a Republic of Texas-era Anglo farmstead that featured slave quarters, as well as a late-nineteenth century to early-twentieth century African-American and Mexican-American sharecropper's homestead.

The Osborn site (41BP314) was continuously occupied between ca. 1906 and 1952, and can be regarded as an earlytwentieth century Mexican-American sharecropper's homestead. This study's conclusions regarding the latter site are presented below. Considering the reciprocity of the designation Mexican and Mexican-American, as applied to these families, subsequent references will simply be Mexican.

\section{Mexican Migration Patterns in Central Texas}

As stated in our research design, we had proposed to frame the Martínez family experience around the social and economic context of Mexican migration and the typical characteristics of the migrant workers. It was believed that by examining the Martínez family evidence in comparison to these characteristics, we could identify both the typical and atypical nature of this family's immigration and settlement story.

Given the evidence, we now know that two erroneous assumptions were made about the Martínez family. The principal assumption was that the Martínez family had emigrated from Mexico, which proved to be false. The other assumption was that the family had resided at the T. C. Osborn tenant house (41BP314), which proved to be partially false. On this last detail, we point out that the Martínez family was associated with 41BP314 through their sharecropping activities on the Osborn Farm.
Although Pedro Martínez and Lucrecia Martínez and their children lived and worked on the Osborn Farm for 38 years (1917-1954), they never lived at the tenant house (41BP314), located at the west-end of the farm. Pedro Martínez and Lucrecia Domínguez were originally from Zapata County, Texas. According to Pete Martínez, Jr., his mother migrated north with her parents by wagon, ca. 1902. We were unable to determine when Pedro Martínez moved from Zapata County to Bastrop County, although it may have been at an early age, since he had some formal schooling and spoke English. We were unable to determine whether or not he migrated to Bastrop County on his own.

David García was originally from Villa Acuña, Coahuila, Mexico, just across from Del Rio, Texas. Mr. García, like Mr. Martínez, also had some formal schooling and spoke English. Mrs. Louise García recalled that he had mentioned being sent by his parents across to Del Rio to stay with an uncle and attend school there. We were unable to determine when David García's parents migrated into this area, but if he was in school up to age 10 or so, this would place the family in Bastrop ca. 1908. Numerous García family members also resided in the area and as noted earlier, Mrs. García's sister, Nemesia, was married to David's brother Samuel. Mrs. Louise Rodríguez García was born in the small community of Cedar Creek in Bastrop County. Her oldest sister Nemesia, however, was born in 1892 in Columbus, Colorado County. This information indicates that the Rodríguez family had migrated to the Cotton Belt region some time before the first big wave of Mexican immigration, and places them in the area by ca. 1892 .

The Barrón family had the earliest documented arrival date into this area. José Barrón's father, Santos Barrón, was born in 1871 in Taylor, Williamson County, north of Austin. His mother, Beatrice Serna, was born in Eagle Pass, Texas. José Barrón was born in Travis County. Mr. Barrón's wife, Virginia Galván, was born in Bastrop. Her mother, Joaquina Rodríguez, was also born in Bastrop in 1886. Her father, Pedro Galván, was born in Mexico, but appears to have been in the area by at least ca. 1915 .

By-and-large then, the Barrón, García, and Martínez families were Texas Mexicans or Tejanos, and were not part of the ca. 1910-17 group of immigrants that fled Mexico as a result of political and economic upheavals. These life experiences prove extremely important in presenting yet another depiction of Mexican-American life in early-twentieth century Texas. 


\section{Social Relations within an Early Twentieth- Century Rural Community}

The preliminary data indicated that site 41BP314 was a "tenant farm" and that the Martínez family operated the farm for T. C. Osborn. This supposed work relationship served to contradict the literature and, if true, would prove quite interesting given that Mexicans were typically not assigned tenant farms. As it turns out, the preliminary data was once again incorrect. None of the families that assisted in this study were ever "tenant farmers." The Martínez, García, and Barrón families were all sharecroppers and, as was typical, they worked for half of the cotton harvested on the assigned acreage. By the 1940s, Pedro Martínez' assigned acreage was about 20 acres per farm hand, as opposed to David García's 10 acres. This difference in assigned acreage indicates that Pedro Martínez enjoyed a certain amount of prestige and autonomy, most probably owing to his years of continuous service to the Osborns.

The literature states that two key factors propelled Mexican emigration. These are termed the "push" and "pull" factors that work in tandem. The "push" factor suggests that, in this case, Mexico's failing economy and political turmoil of the early-twentieth century actually pushed many away from their homes. The "pull" factor suggests that the better-paying jobs in agriculture, mining, and railroads, which was further enticed by existing social connections across the border, pulled many towards the U.S. In considering the actual life experiences summarized above, we would have to agree that in every case, the "push" and "pull" factors were at play here. However, we would argue that these families did not wait for situations to worsen before seeking to improve their lives. These families arrived in central Texas during the 1870-1890s, while others arrived during the first decade of the 1900s, well before things deteriorated along the border.

With respect to established social networks, the evidence suggests that these families moved purposefully, and that they relied on support networks of friends and relatives. As in the case of Pedro Martínez, two of his brothers-in-law, Livorio González and Asención Domínguez, also worked for T. C. Osborn. By all indications, both González and Domínguez were already at the Osborn Farm when the Martínez family arrived in 1917. As described by José Barrón, the weekly gatherings held by the Mexican families in Phelan were important, as this was probably their only means of channeling and extending social relations. Just as important were the religious and family bonds established by the congregation of the Mexican Baptist Church, as exemplified by the García-Rodríguez families.

Examples of how these families interacted with the community at-large are sketchy. Beyond the routine businessrelated transactions, social interaction between Mexican and Anglo appears to have been minimal. The strongest evidence for this lies in the fact that the public schools were segregated up until 1949. Educational and oratorical skills notwithstanding, Mrs. Nemesia García proved quite capable of asserting her child's civil rights, and those of countless other children. As for business relationships, the most often mentioned were Rabensburg Grocery and Dr. Combs. It seems that E. J. Rabensburg and Dr. Henry B. Combs were the Mexican community's grocer and physician of choice. Edward J. Rabensburg appears to have been more than just a grocer to the Mexican community. He personally appeared at the courthouse in order to attest to the births of two of Livorio González' children. Dr. Combs, who seems to have started his practice in 1898 , was the only physician in Bastrop that attended to the health needs of the Mexican community. Dr. Combs, who lived to the age of 94 , attended to the births of two of the García children and all of the Martínez children.

There are two principal cemeteries in the town of Bastrop. The oldest and largest is Fairview, which includes an African American section. The other is Alta Vista Cemetery, or the "Latin" cemetery located within one-half mile to the east of the Osborn Farm. The earliest burial in Alta Vista Cemetery dates to 1929, and most of the Barrón, García, and Martínez family members and close relations are buried here. We were unable to determine the exact history of this cemetery, and believe that it was organized, most likely, by the Mexican Baptist community ca. 1929. Figure 17 depicts the town of Bastrop at ca. 1982. The site is shown on the extreme south end of the illustration; the Alta Vista Cemetery is seen in close proximity to the farm, and Fairview Cemetery is seen at the far northwest end of the town.

Figures 2 and 18 depict the site as it appears today. Figure 2 is from a USGS aerial taken ca. 1998, the footprint of the site is indicated as being located near the bottom center of the photo. The Colorado River is seen to the far left and the Gills Branch Creek appears as a meandering line of trees, above the site. Figure 18 is a present-day perspective of the site, and was taken at ground level. The footprint of the site appears almost at center, with the house of Bro. Paul Bell seen above and to the right of the site. 


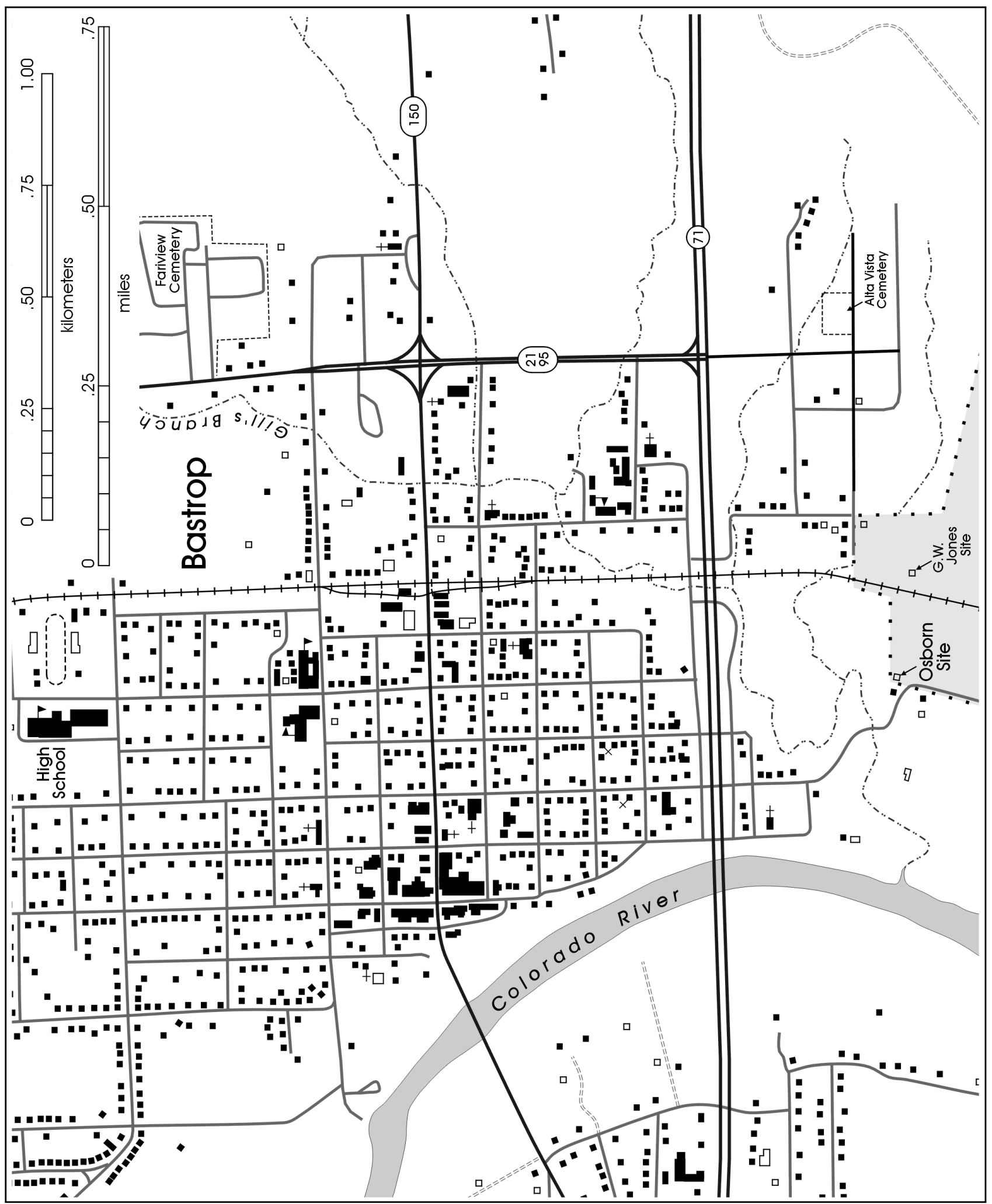

Figure 17. Town of Bastrop ca. 1982. 


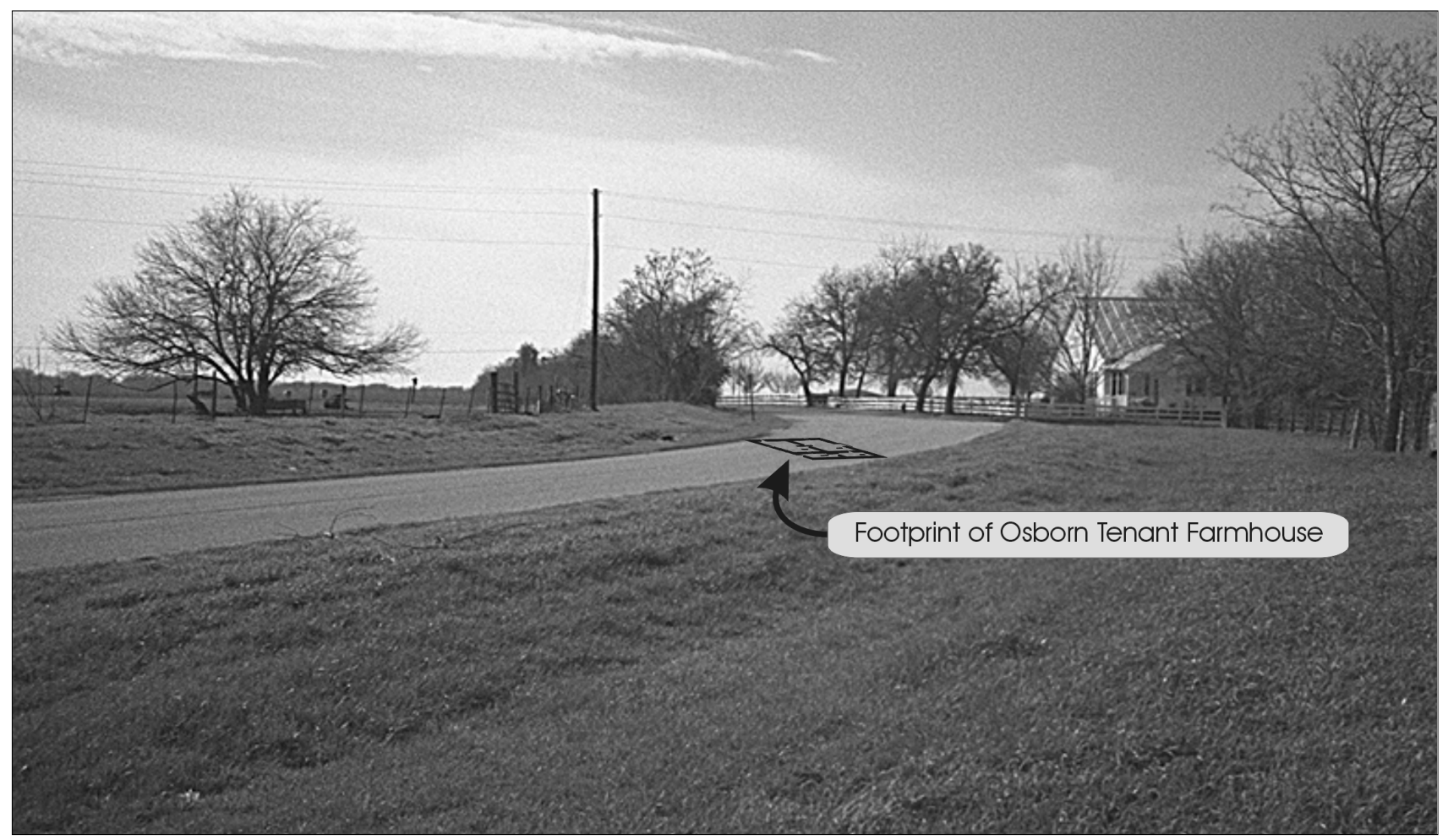

Figure 18. Present-day view of site-view to the south, down Lovers Lane. (Photo taken January 2001.)

Understandably, this is a superficial treatment of the very complicated institution of tenant farming that existed throughout the cotton belt of central Texas. Nevertheless, in concluding, we extend the following statement: considering the time and the place, the hardships endured and the advancements realized, this group of sharecroppers can be characterized as possessing a daring spirit, a deep sense of family loyalty, a strong work ethic, tenacity, and above all, optimism. 


\section{References Cited}

American Memory

2001 Historical Collections for the National Digital Library, Slave Narratives from the Federal Writers' Project 19361938. <http://memory.loc.gov> Accessed August.

Baker, F. E.

1979 Soil Survey of Bastrop County, Texas. National Cooperative Soil Survey. U.S. Department of Agriculture, Washington, D.C.

Balkwill, D. M., and S. L. Cumbaa

1992 A Guide to the Identification of Postcranial Bones of Bos taurus and Bison bison. Canadian Museum of Nature, Ottawa.

Barr, A.

1973 Black Texans: A History of Negroes in Texas, 1528-1971. Jenkins Publishing Company, Austin.

Bastrop Advertiser [Bastrop, Texas]

1910 Advertisement for slate writing tablets. 8 October. Microfilm roll, vol. 58, no. 25, Bastrop Public Library, Bastrop, Texas.

Bastrop Central Appraisal District [BCAD]

1999 Aerial Photograph 10-11 (ca. 1999), of south-central Bastrop, Bastrop County, Texas.

Brown, M., J. E. Zapata, and B. K. Moses

1998 Camp Elizabeth, Sterling County, Texas: An Archaeological and Archival Investigation of a U.S. Army Subpost, and Evidence Supporting Its Use by the Military and "Buffalo Soldiers." Archaeological Survey Report, No. 267. Center for Archaeological Research, The University of Texas at San Antonio.

Clark, V. S.

1999 Comments on Changes in Mexican Immigration to the United States, 1908. In Major Problems in Mexican American History, edited by Z. Vargas, pp. 204-207. Houghton Mifflin Company, Boston, Massachusetts.

Clonts, J. B.

1983 Some Long Overdue Thoughts on Faunal Analysis. In Forgotten Places and Things: Archaeological Perspectives on American History, edited by A. E. Ward, pp. 349-354. Center for Anthropological Studies, Albuquerque, New Mexico.

Cohen, A., and D. Serjeantson

1996 A Manual for the Identification of Bird Bones from Archaeological Sites. Revised edition. Archetype Publications, London.

Fox, A. A., M. Renner, and R. J. Hard (editors)

1997 Archaeology at the Alamodome: Investigations of a San Antonio Neighborhood in Transition, Volume III: Artifacts and Special Studies. Archaeological Survey Report, No. 283. Center for Archaeological Research, The University of Texas at San Antonio.

García, J. R.

1996 Mexicans in the Midwest, 1900-1932. University of Arizona Press, Tucson. 
Gilbert, B. M.

1990 Mammalian Osteology. Missouri Archaeological Society, Columbia.

Glencoe Mill and Mill Village Historic District

2001 Criteria Assessment, Section 8, Glencoe Historic District National Register Nomination Form, Faucette Township, North Carolina 1979.

<http://www.gendex.com/users/kcates/glencoe/library/doc3.htm> Accessed January 15.

Gómez-Quiñones, J.

1994 Mexican American Labor, 1790-1990. University of New Mexico Press, Albuquerque.

Gore, M. B. T.

1979 The Thomas Claiborne Osborn Home. Annotated site and family history, Bastrop, Texas, May 24, 1979 [Craig Pence Collection].

Grayson, D. K.

1984 Quantitative Zooarchaeology. Academic Press, New York.

Hall, L. B., and D. M. Coerver

1988 Revolution on the Border: The United States and Mexico, 1910-1920. University of New Mexico Press, Albuquerque.

Handbook of Texas Online

2000 Texas State Historical Association, The General Libraries at the University of Texas at Austin.

$<$ http://www.tsha.utexas.edu/handbook/online $>$ Accessed December 15.

Hildebrand, M.

1955 Skeletal Differences Between Deer, Sheep, and Goats. California Fish and Game 41:327-346.

Hillson, S.

1986 Teeth. Cambridge University Press, Cambridge.

Iredell, G. S.

1920 Map of Bastrop, Texas. By George S. Iredell, Civil Engineer, June 1920.

Kennedy, I. K., and J. L. Kennedy

1987 Genealogical Records in Texas. Genealogical Publishing Co., Inc., Baltimore, Maryland.

Kesselus, K.

1986 History of Bastrop County, Texas Before Statehood. Jenkins Publishing, Austin, Texas.

Lower Colorado River Authority

2000 Community Profile - City of Bastrop, Texas.

$<$ http://www.lcra.org $>$ Accessed December 22.

Lyman, R. L.

1994 Vertebrate Taphonomy. Cambridge University Press, Cambridge, Massachusetts. 
McAlester, V., and L. McAlester

1986 A Field Guide to American Houses. Alfred A. Knopf, New York.

McGraw, A. J., J. W. Clark, Jr., and E. A. Robbins (editors)

1998 A Texas Legacy - The Old San Antonio Road and the Caminos Reales: A Tricentennial History, 1691-1991. Second edition. Texas Department of Transportation, Austin.

Maldonado, L. A.

1985 Altered States: Chicanos in the Labor Force. In Ethnicity and the Workforce, vol. IV, edited by W. A. Van Horne and T. V. Tonnesen, pp. 145-166. University of Wisconsin System, American Ethnic Studies Coordinating Committee/Urban Corridor Consortium, Madison.

Meissner, B. A.

1997a Dolls, Toys, Games, and Other Diversions. In Archaeology at the Alamodome: Investigations of a San Antonio Neighborhood in Transition, Volume III: Artifacts and Special Studies, edited by A. A. Fox, M. Renner, and R. J. Hard, pp. 57-99. Archaeological Survey Report, No. 238. Center for Archaeological Research, University of Texas at San Antonio.

1997b Making the Man: Remains of Clothing Recovered from the Alamodome Project. In Archaeology at the Alamodome: Investigations of a San Antonio Neighborhood in Transition, Volume III: Artifacts and Special Studies, edited by A. A. Fox, M. Renner, and R. J. Hard, pp. 119-164. Archaeological Survey Report, No. 238. Center for Archaeological Research, The University of Texas at San Antonio.

Menefee, S. C.

1941 Mexican Migratory Workers of South Texas. Federal Works Agency, Work Projects Administration, Washington, D.C.

Montejano, D.

1987 Anglos and Mexicans in the Making of Texas, 1836-1986. University of Texas Press, Austin.

Moore, W. E.

1977 Bastrop County, 1691-1900. Nortex Press, Wichita Falls, Texas.

MSN TerraServer ${ }^{\circ}$

20001998 United States Geological Survey aerial map of Bastrop.

$<$ http://terraserver.microsoft.com>

National Weather Service -Southern Region

$2000<$ www.srh.noaa.gov>

Olsen, S. J.

1960 Post-Cranial Skeletal Characters of Bison and Bos. Peabody Museum, Cambridge, Massachusetts.

1964 Mammal Remains from Archaeological Sites: Part I. Southeastern and Southwestern United States. Peabody Museum, Cambridge, Massachusetts.

1968 Fish, Amphibian, and Reptile Remains from Archaeological Sites: Part I. Southeastern and Southwestern United States. Peabody Museum, Cambridge, Massachusetts. 
Raab, L. M.

1982 Settlement of the Prairie Margin: Archaeology of the Richland Creek Reservoir, Navarro and Freestone Counties, Texas, 1980-1981. Archaeological Monographs, No. 1. Archaeology Research Program, Southern Methodist University, Dallas.

Randolph Blueprint Company 1929 Map of Bastrop County, Texas. Map No. 55 (ca. 1929), Randolph Blueprint Co., San Antonio, Texas.

Reitz, E. J., and E. S. Wing

1999 Zooarchaeology. Cambridge University Press, Cambridge, Massachusetts.

Robinson, D. G.

1989 Historical Research at the George Washington Jones Homestead 41BP86, Bastrop County, Texas. Technical Series No. 11, Texas Archeological Research Laboratory, The University of Texas at Austin.

RootsWeb.com

$2000<$ www.rootsweb.com/ txbastro/bastrop.htm>

Ross, S.

1993 An Evaluation of Documentation and Materials from Site 41BP314, The T. C. Osborn House Site, Bastrop County, Texas. Texas Archeological Research Laboratory, The University of Texas at Austin.

Schulz, P. D., and S. M. Gust

1983 Faunal Remains and Social Status in 19th Century Sacramento. Historical Archaeology 17(1):44-53.

Sobolik, K. D., and D. G. Steele

1996 A Turtle Atlas to Facilitate Archaeological Identifications. Mammoth Site of Hot Springs, South Dakota, Inc., Rapid City.

Taylor, T. U.

1934 Thomas Clayborn Osborne. In Frontier Times 11(7):318.

Texas Historic Site Atlas

2000 National Register of Historic Places, listing and descriptions for Bastrop County. Texas Historical Commission. $<$ http://www.atlas.thc.state.tx.us> Accessed December 6.

Toulouse, J. H.

1971 Bottle Makers and Their Marks. Thomas Nelson, New York.

United States Geological Survey (USGS)

1982 Bastrop Quadrangle Map, 3097-121, Bastrop County, Texas. USGS, Denver, Colorado.

United States House of Representatives (USHR)

1920 United States House of Representatives, Hearings Before the Committee on Immigration and Naturalization Temporary Admission of Illiterate Mexican Laborers, Jan 26, 27, 28, 30, and Feb 2, 1920. 
United States Senate (USS)

1920 United States Senate, Hearing Before the Committee on Immigration, United States Senate - Admission of Mexican Agricultural Laborers, Jan 27, 1920.

U. S. Historical Census Data Browser

$2000<$ http://fisher.lib.virginia.edu/census $>$

Vargas, Z.

1999 Mexican Immigrants in the Midwest. In Major Problems in Mexican American History, edited by Z. Vargas, pp. 254-265. Houghton Mifflin, Boston, Massachusetts.

Zamora, E.

1993 The World of the Mexican Worker in Texas. Texas A\&M University Press, College Station.

Zapata, J. E.

1997 Alamodome and Abroad: A Composite Inquiry on Toy Marbles. In Archaeology at the Alamodome: Investigations of a San Antonio Neighborhood in Transition, Volume III: Artifacts and Special Studies, edited by A. A. Fox, M. Renner, and R. J. Hard, pp. 100-115. Archaeological Survey Report, No. 238. Center for Archaeological Research, The University of Texas at San Antonio.

\section{Archives and Collections Consulted}

BCC - Bastrop County, County Clerks Office

BPL - Bastrop Public Library

Craig Pence Personal Collection, Bastrop, Bastrop County, Texas

USDCa - United States Department of Commerce, Schedule 5. Agricultural and Manufacturing Census Records, 1850 and 1880 .

USDCb - United States Department of Commerce, Bureau of the Census, Schedule 1. Population Schedules, Free Inhabitants 1850 and 1860.

USDCc - United States Department of Commerce, Bureau of the Census, Schedule 2. Slave Population, 1850 and 1860.

USDCd - United States Department of Commerce, Bureau of the Census, Schedule 1. Population 1900. 


\section{Oral Histories}

Barrón, José (95-year-old) of Bastrop, Texas - Tape No. 1-A, 6 Dec. 2000.

García, Louise (93-year-old) of Bastrop, Texas - Tape No. 3-B; Tape No. 4-A, 7 Dec. 2000.

Martínez, Pete, Jr. (68-year-old) of Austin, Texas - Tape No. 2-A \& 2-B; Tape No. 3-A, 7 Dec. 2000.

Martínez, Rudy (61-year-old) of Bastrop, Texas - Tape No. 2-A \& 2-B, 7 Dec. 2000.

Rockwell, Emma García (73-year-old) of Lewisburg, West Virginia - Tape No. 3-B; Tape No. 4-A, 7 Dec. 2000.

\section{Photo Credits}

Figure 9a - Elof Gustafson plowing behind four mules. Postcard photo by Jordan Photo, Austin, Texas, Institute of Texan Cultures, The University of Texas at San Antonio, No. 86-176.

Figure $9 \mathrm{~b}$ - A man hoeing cotton near El Paso, Texas, along U.S. 80. Texas Highway Department, Institute of Texan Cultures, The University of Texas at San Antonio, No. 75-963.

Figure 9c - Men in field picking cotton, Bexar County, Texas. San Antonio Light Collection, Institute of Texan Cultures, The University of Texas at San Antonio, No. 1238-B.

Figure 9d - Picking cotton on Pavliska farm near Granger, Texas. Courtesy of Nancie Pavliska Roddy, Institute of Texan Cultures, The University of Texas at San Antonio, No. 98-158.

Figure 9e - Cotton wagons turning off Main Street on to First Street on trip from gin to cotton yard, Elgin, Texas, Courtesy of Leo Foehner, Institute of Texan Cultures, The University of Texas at San Antonio, No. 96-1312. 

Appendix A

Artifact Catalog 
Table A-1. Artifact Catalog

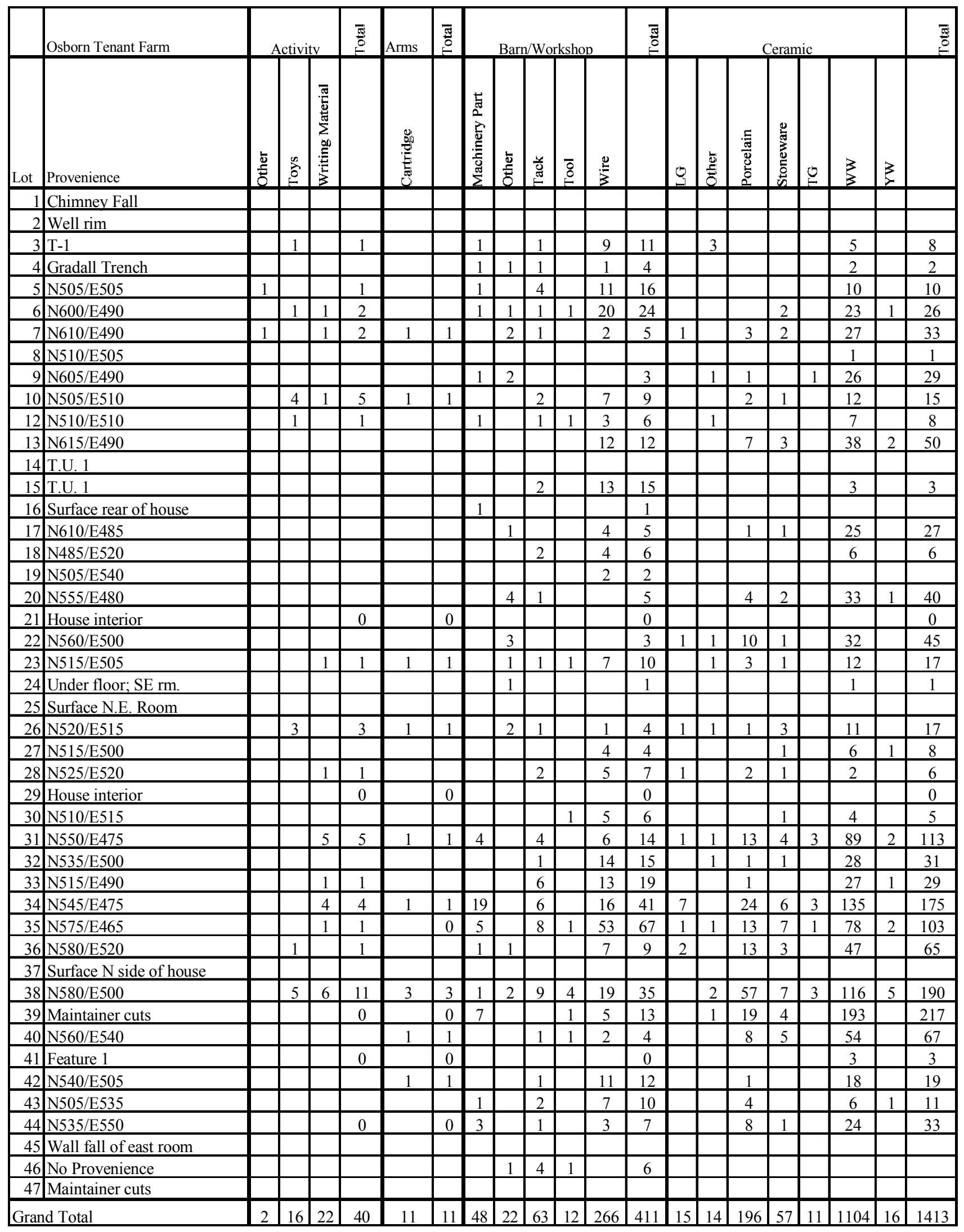


Table A-1. continued...

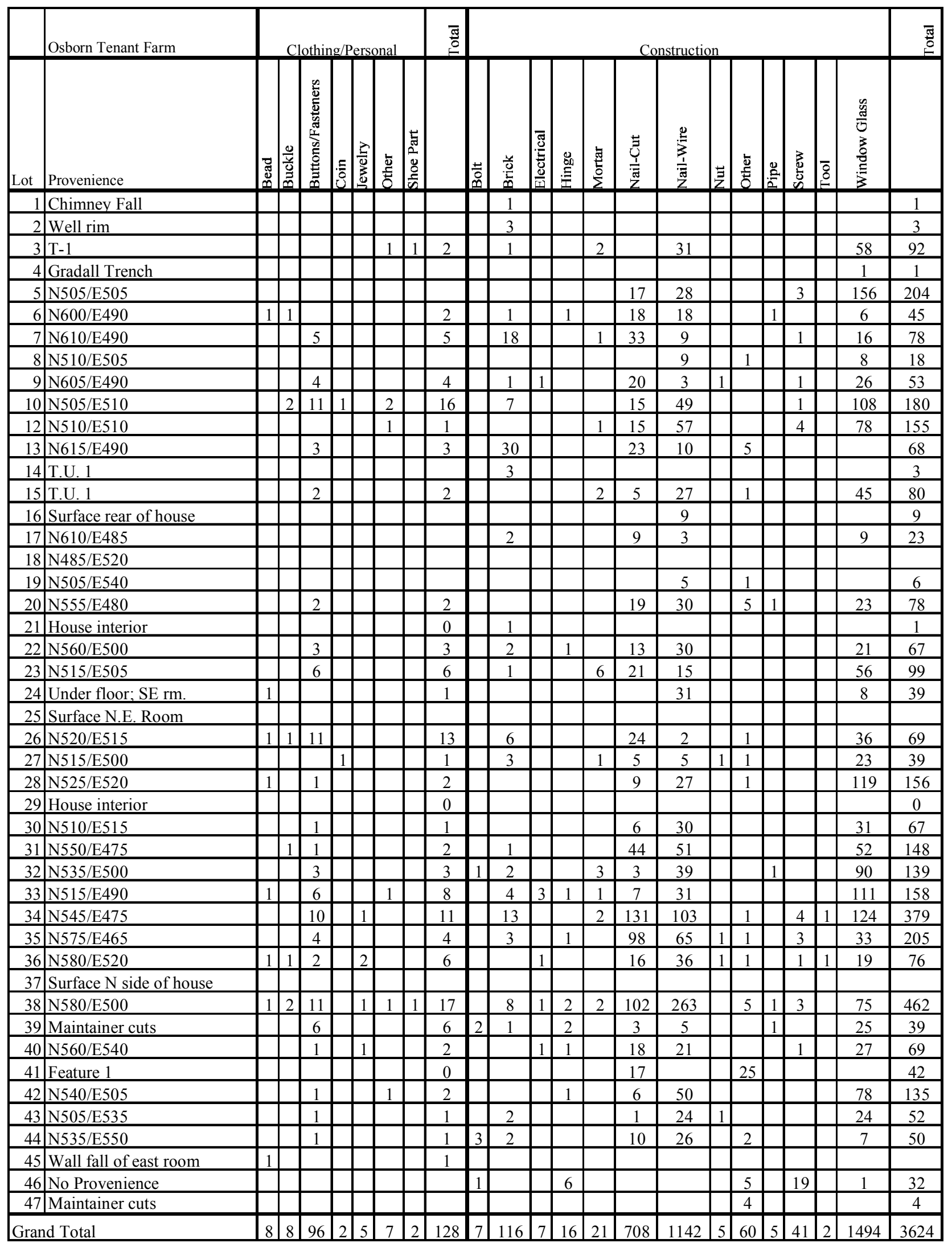


Table A-1. continued...

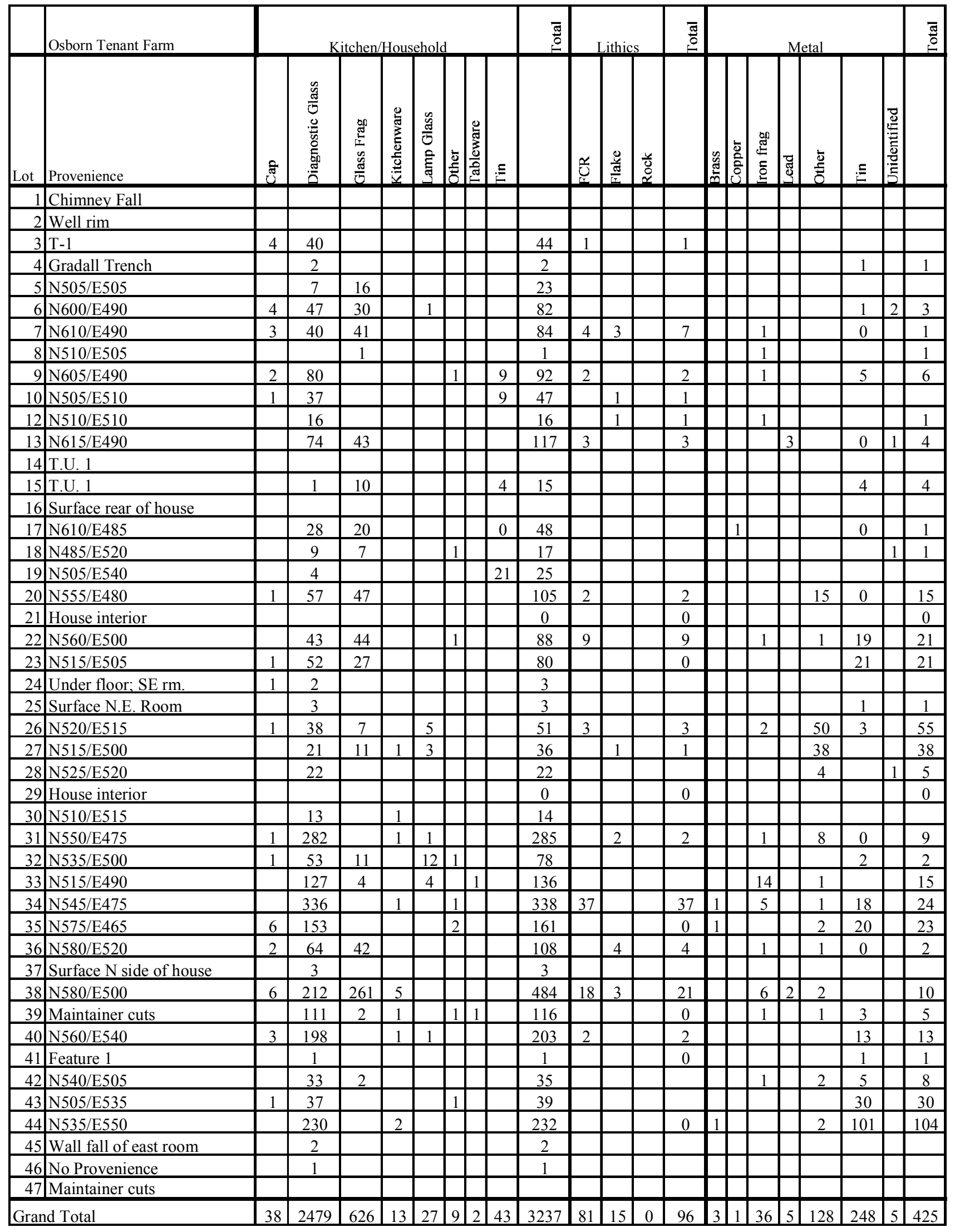


Table A-1. continued...

\begin{tabular}{|c|c|c|c|c|c|c|c|c|c|c|c|c|c|c|c|}
\hline & Osborn Tenant Farm & & & & cella & aneo & & & & 盶 & & Shell & & बू & $\begin{array}{l}\text { Grand } \\
\text { Total }\end{array}$ \\
\hline Lot & Provenience & 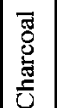 & $\frac{0}{0}$ & 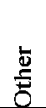 & ఫ్ & $\mid \begin{array}{l}\frac{0}{2} \\
\frac{\pi}{2} \\
\frac{\pi}{2}\end{array}$ & 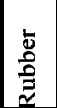 & Z & \% & & 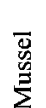 & 站 & 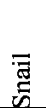 & & \\
\hline 1 & Chimney Fall & & & & & & & & & & & & & & 1 \\
\hline 2 & Well rim & & & & & & & & & & & & & & 3 \\
\hline 3 & $\mathrm{~T}-1$ & & & & & & & & & & 5 & & 1 & 6 & 165 \\
\hline 4 & Gradall Trench & & & & & & & & & & & & & & 10 \\
\hline 5 & N505/E505 & 2 & & & & & & & & 2 & 1 & & & 1 & 257 \\
\hline 6 & $\mathrm{~N} 600 / \mathrm{E} 490$ & 2 & & & & 1 & & & & 3 & & & & & 187 \\
\hline 7 & N610/E490 & & & & & & 2 & & & 2 & & & 8 & 8 & 226 \\
\hline 8 & $\mathrm{~N} 510 / \mathrm{E} 505$ & & & & & & & & 2 & 2 & & & & & 23 \\
\hline 9 & N605/E490 & & & & & 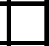 & 1 & & & 1 & 3 & & & 3 & 193 \\
\hline 10 & $\mathrm{~N} 505 / \mathrm{E} 510$ & 1 & & & & 1 & 13 & & 1 & 16 & 2 & & 1 & 3 & 293 \\
\hline 12 & N510/E510 & & & & & $\square$ & & & & & 1 & & 2 & 3 & 192 \\
\hline 13 & $\mathrm{~N} 615 / \mathrm{E} 490$ & & & & & 1 & 1 & & & 2 & 4 & & & 4 & 263 \\
\hline 14 & T.U. 1 & & & & & & & & & & & & & & 3 \\
\hline 15 & T.U. 1 & & & & & & & & & & & & 8 & 8 & 127 \\
\hline 16 & Surface rear of house & & & & & & & & & & & & & & 10 \\
\hline 17 & $\mathrm{~N} 610 / \mathrm{E} 485$ & 1 & & & & & 1 & & & 2 & & & 1 & 1 & 107 \\
\hline 18 & $\mathrm{~N} 485 / \mathrm{E} 520$ & & & & & & & & & & & & & & 30 \\
\hline 19 & $\mathrm{~N} 505 / \mathrm{E} 540$ & & & & & & & & & & & & & , & 33 \\
\hline 20 & $\mathrm{~N} 555 / \mathrm{E} 480$ & 2 & & & & & 1 & & & 3 & 1 & & 1 & 2 & 252 \\
\hline 21 & House interior & & & & & & & & & 0 & & & & 0 & 1 \\
\hline 22 & $\mathrm{~N} 560 / \mathrm{E} 500$ & 8 & & & & & & & & 8 & & & & 0 & 244 \\
\hline 23 & N515/E505 & & 3 & 20 & 0 & & & 3 & 1 & 27 & 1 & & 3 & 4 & 266 \\
\hline 24 & Under floor; SE rm. & & & & 4 & & & & & 4 & & & & & 49 \\
\hline 25 & Surface N.E. Room & & & & & & & & & & & & & & 4 \\
\hline 26 & N520/E515 & 2 & 4 & 6 & 2 & 2 & 1 & 1 & & 18 & 7 & & & 7 & 241 \\
\hline 27 & N515/E500 & & & 2 & & & & & & 2 & & & & & 129 \\
\hline 28 & N525/E520 & & & & 2 & & & & & 2 & 1 & & & 1 & 202 \\
\hline 29 & House interior & & & & & & & & & 0 & & & & 0 & 0 \\
\hline 30 & N510/E515 & & & & & & & & & & 3 & & & 3 & 96 \\
\hline 31 & N550/E475 & 1 & & & & & & & & 1 & 7 & & & 7 & 587 \\
\hline 32 & $\mathrm{~N} 535 / \mathrm{E} 500$ & 1 & & & & & & & & 1 & 9 & & & 9 & 278 \\
\hline 33 & N515/E490 & & & & & & & 1 & & 1 & 4 & & & 4 & 371 \\
\hline 34 & $\mathrm{~N} 545 / \mathrm{E} 475$ & 1 & & 1 & & & & & & 2 & 11 & & & 11 & 1023 \\
\hline 35 & N575/E465 & 1 & & 1 & & & & & & 2 & 4 & & & 4 & 570 \\
\hline 36 & $\mathrm{~N} 580 / \mathrm{E} 520$ & 11 & & & & & & & & 11 & 3 & & & 3 & 285 \\
\hline 37 & Surface N side of house & & & & & & & & & & & & & & 3 \\
\hline 38 & N580/E500 & 4 & & 15 & & & 2 & & & 21 & & & & & 1254 \\
\hline 39 & Maintainer cuts & & & & & & & & & 0 & 5 & & & 5 & 401 \\
\hline 40 & $\mathrm{~N} 560 / \mathrm{E} 540$ & & & & & & & & & & 2 & & & 2 & 363 \\
\hline 41 & Feature 1 & & & & & & & & & 0 & 2 & & & 2 & 49 \\
\hline 42 & $\mathrm{~N} 540 / \mathrm{E} 505$ & 5 & & & & & & & & 5 & 2 & & & 2 & 219 \\
\hline 43 & $\mathrm{~N} 505 / \mathrm{E} 535$ & & & 1 & & & & & & 1 & 1 & & & 1 & 145 \\
\hline 44 & $\mathrm{~N} 535 / \mathrm{E} 550$ & & & 1 & & & 1 & & & 2 & 3 & & & 3 & 432 \\
\hline 45 & Wall fall of east room & & & & & & & & & & & & & & 3 \\
\hline 46 & No Provenience & & & & & & & & & & & & & & 39 \\
\hline 47 & Maintainer cuts & & & & & & & & & 0 & & & & 0 & 4 \\
\hline Gran & ad Total & 42 & 7 & 47 & 8 & 5 & 23 & 5 & 4 & 141 & 82 & 0 & 25 & 107 & 9633 \\
\hline
\end{tabular}





\section{Appendix B}

Data Recovered from Faunal Material 


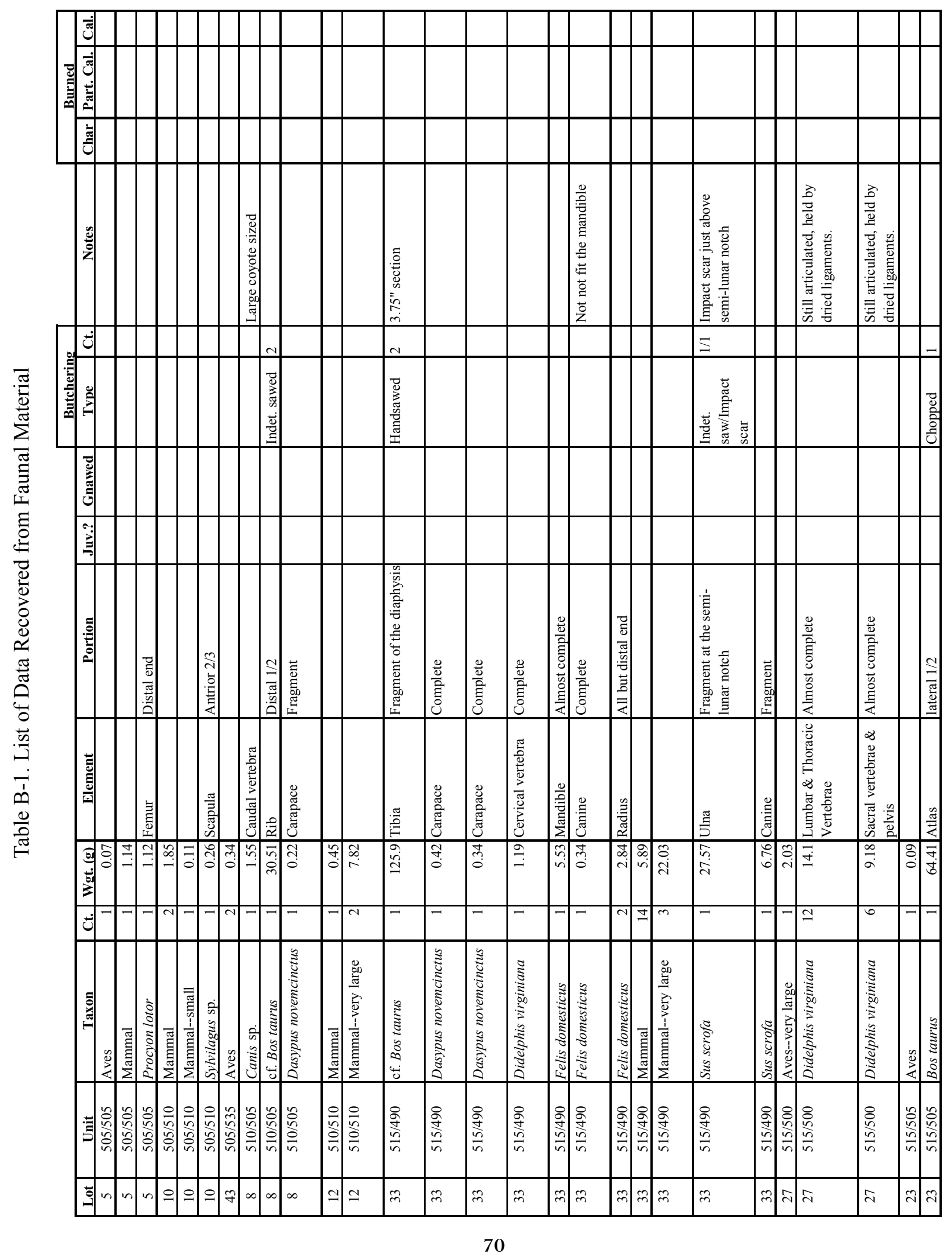




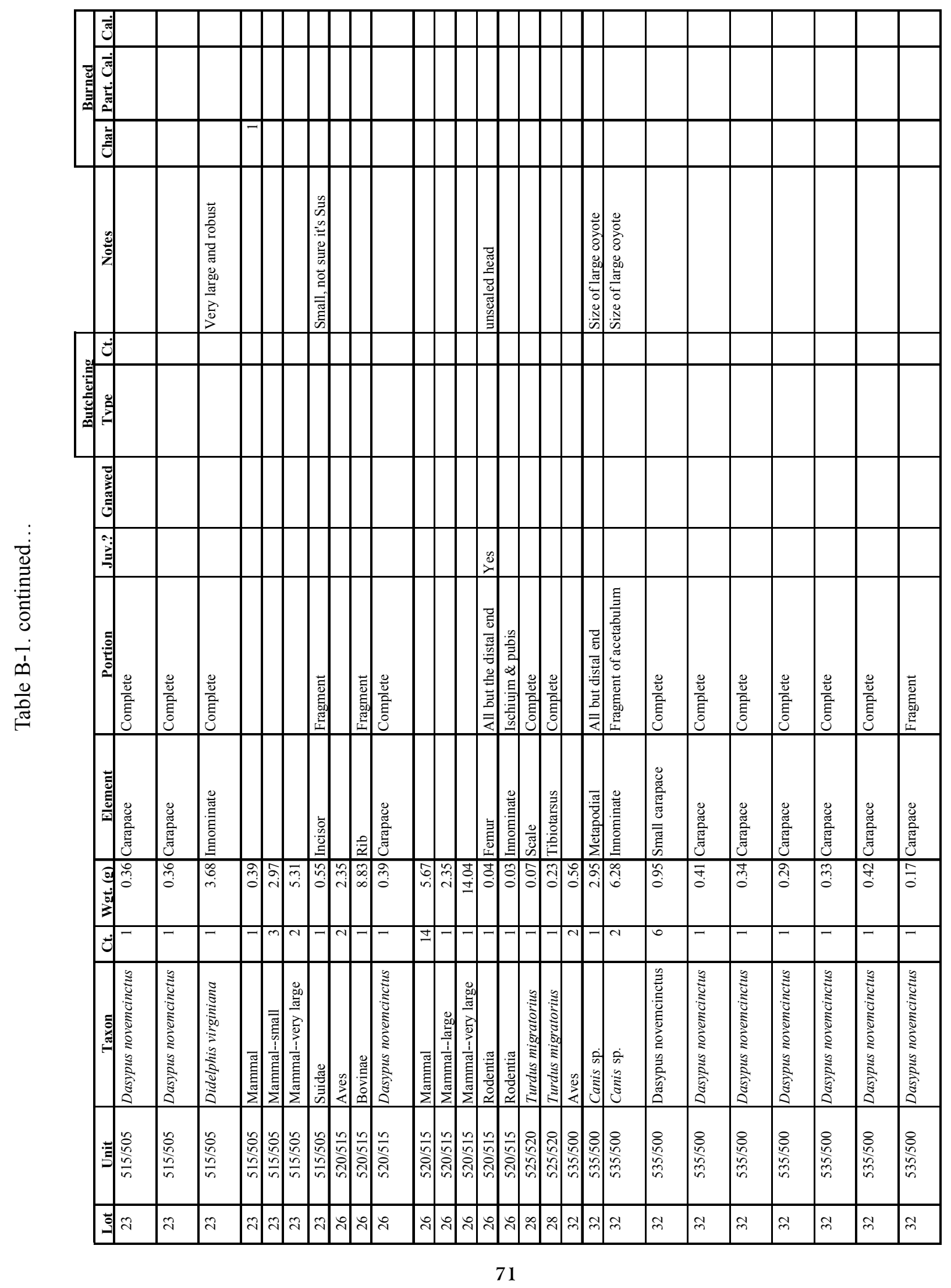




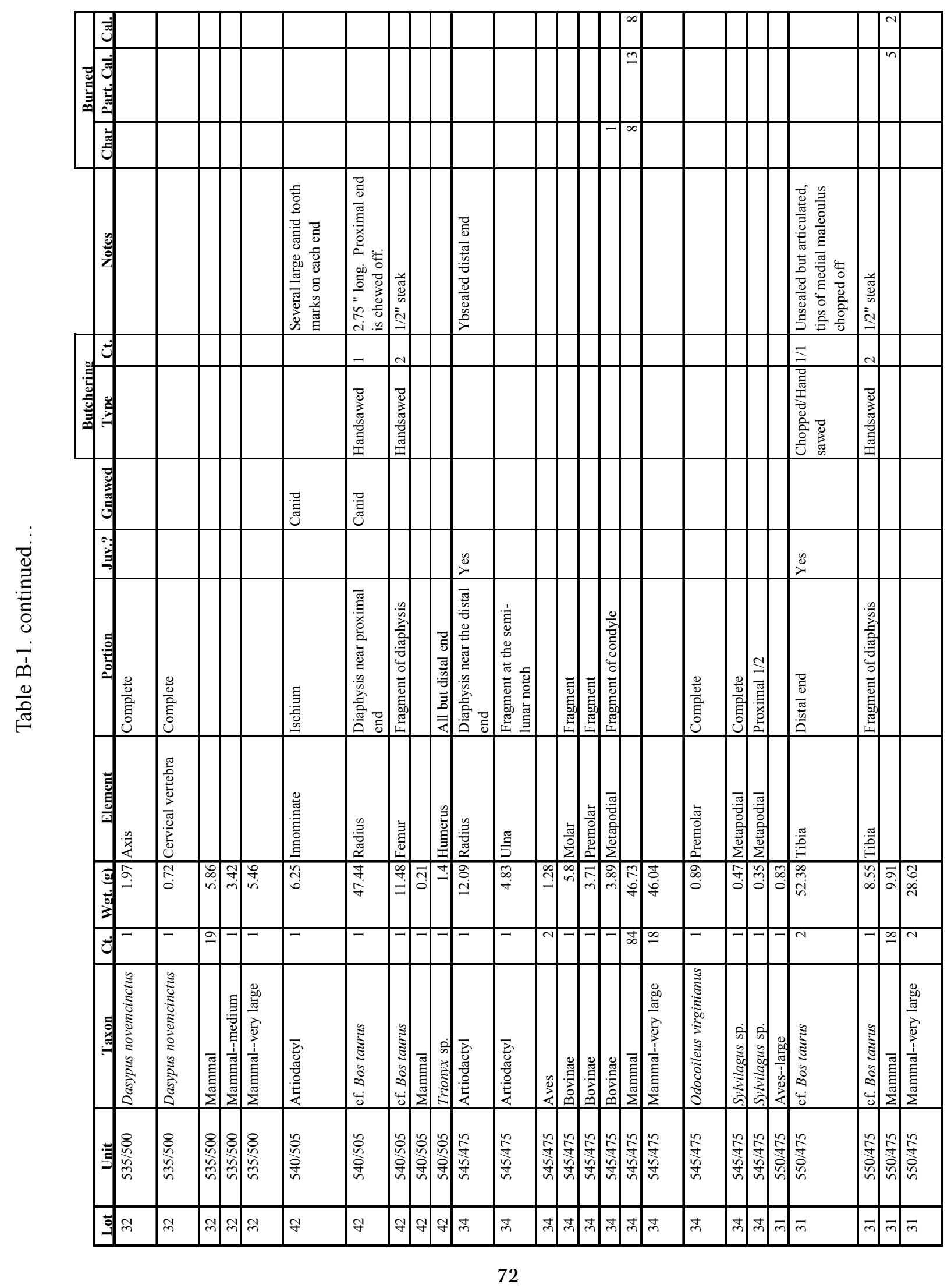




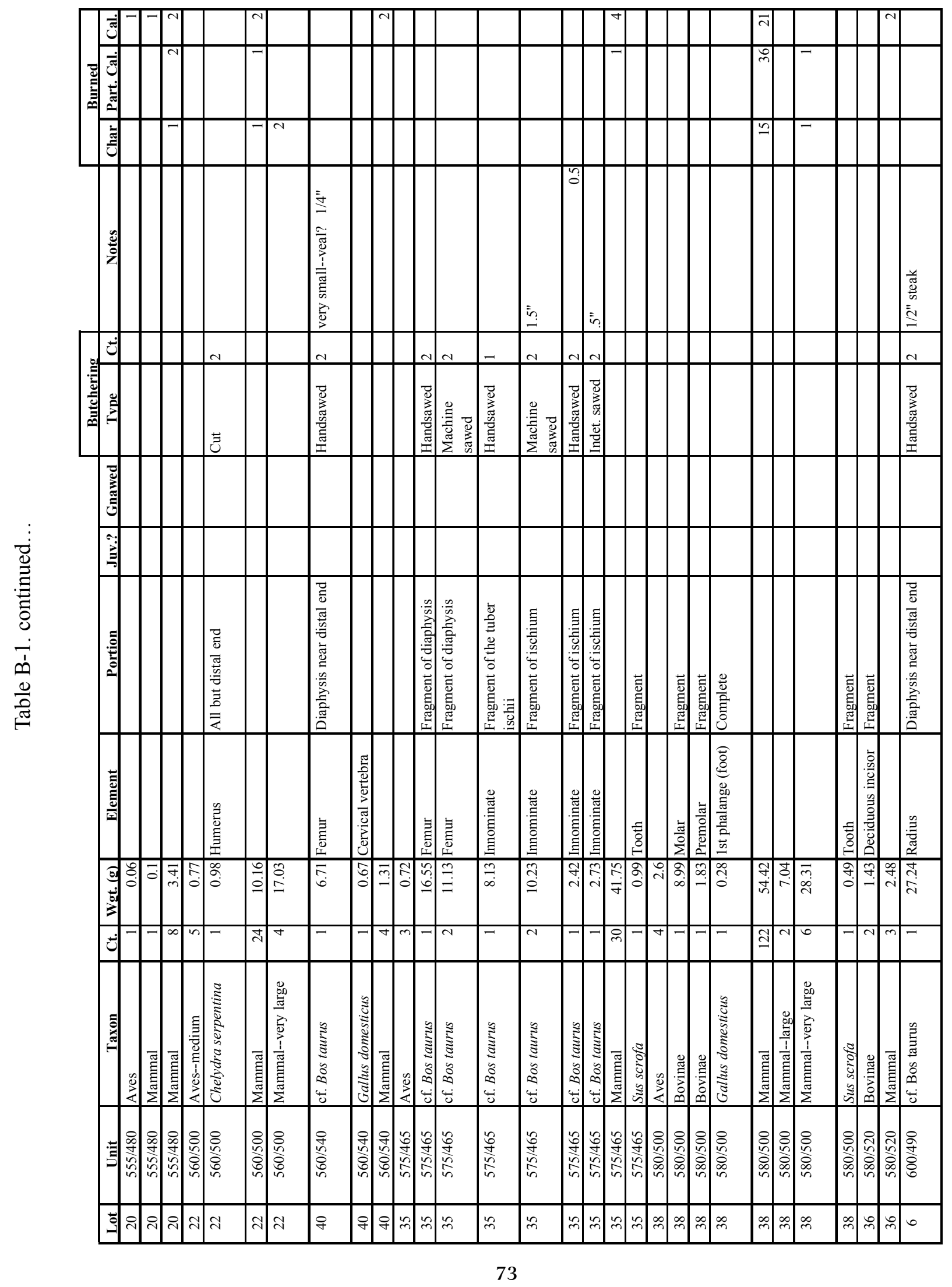




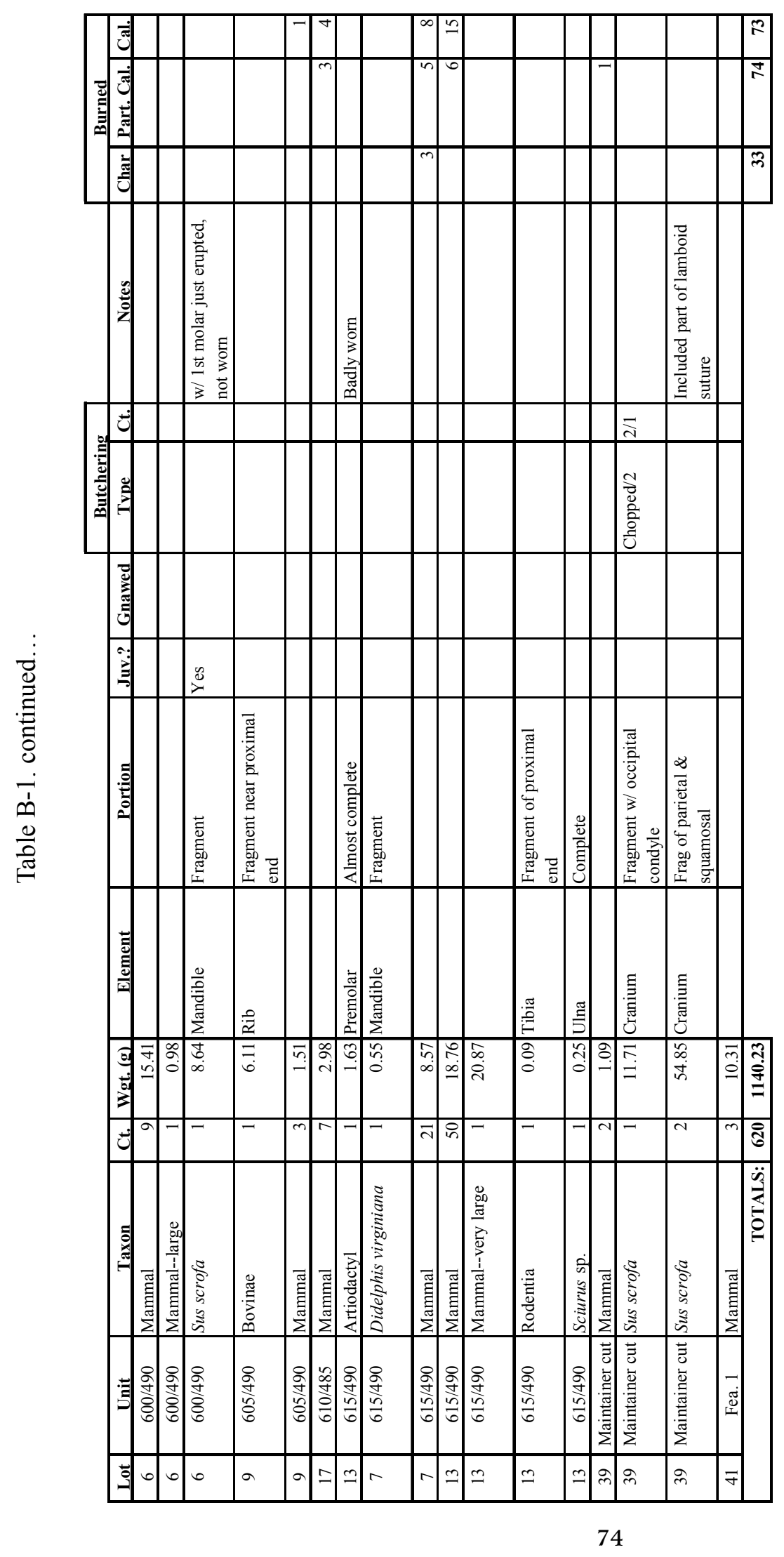


The following information is provided in accordance with the General Rules of Practice and Procedure, Chapter 41.11 (Investigative Reports), Texas Antiquities Committee:

1. Type of investigation: Archival, artifactual, and historical research

2. Project name: Osborn Tenant House

3. County: Bastrop

4. Principal investigator: Nancy A. Kenmotsu

5. Name and location of sponsoring agency: Texas Department of Transportation, Environmental Affairs Division, 125 E. 11th Street, Austin, Texas 78701-2483

6. Texas Antiquities Permit No.: 598

7. Published by the Center for Archaeological Research, The University of Texas at San Antonio, 6900 N. Loop 1604 W., San Antonio, Texas 78249-0658, 2001

A list of publications offered by the Center for Archaeological Research is available. Call (210) 458-4378; write to the Center for Archaeological Research, The University of Texas at San Antonio, 6900 N. Loop 1604 W., San Antonio, Texas 78249-0658; e-mail to car@lonestar.utsa.edu; or visit CAR's web site at http://car.utsa.edu. 